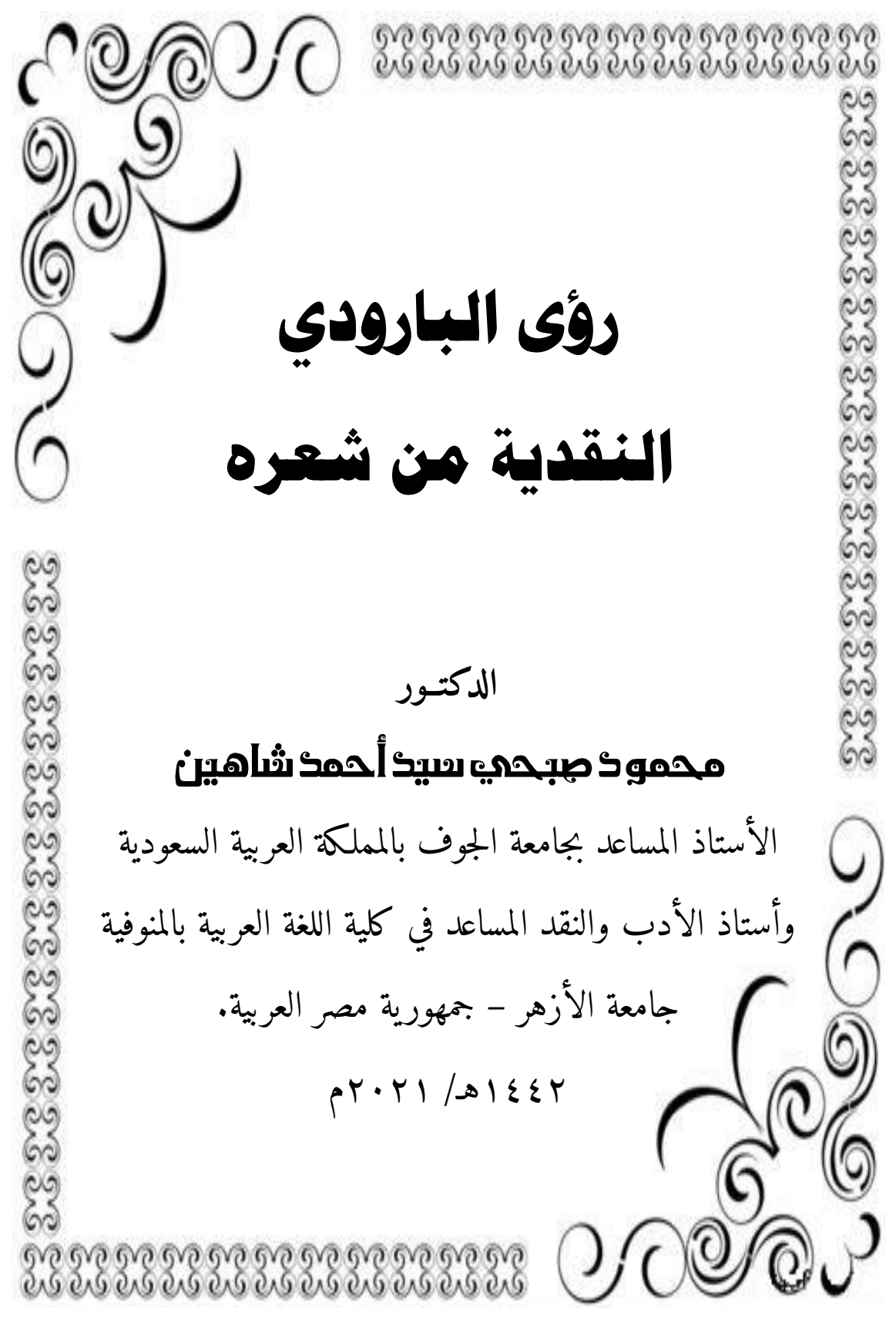


رؤى البارودي النقدية من شعره 


\section{رؤى البارودي النقدية من شعره}

\section{محمود صبحي سيد أحمد شاهين}

قسم اللغة العربية، كلية العلوم والآداب بطبرجل، جامعة الجوف، السعودية.

قسم الأدب والنقد، كلية اللغة العربية بالمنوفية، جامعة الأزهر ، مصر. البريد الإكتروني drmahmoudv • @gmail.com

الملخص:

هدفت هذه الدراسة إلى إبراز رؤى البارودي النقدية من خلال منجزه الشعري، وهو بعد يكاد يكون مطمورا ؛ خاصة أن من تناولوا البارودي في دراسات سابقة تتاولوه من خلال منجزه الشعري الذي عرف به شاعرا، مستظهرين منه الأغراض وما يتخللها من فنيات، ولم يشيروا إلى ما لديه من رؤى نقدية عديدة بثها في شعره، باستثناء بعض الإشارات الخواطف التي تكاد تكون

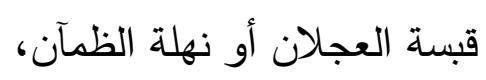

ومن ثم فان قراءة شعر البارودي واستخراج الأبيات والقصائد التي تشكل مجموع رؤاه النقدية حول الشعر في ضميمة واحدة يعد تغريدا جديدا طريفا، وإبرازا لهذا الجانب الذي أراه - من وجهة نظري- غير مطروق من قبل. وقد التزمت الدراسة المنهج الوصفي الذي روعي فيه رصد هذه الرؤى المنضوية في المباحث الخمسة مع الاستعانة في كثير من الأحيان بالمنهج الفني في تحليل مغردة من مفردات رؤية معينة على مستوى بيت بعينه أو بأ مجموعة أبيات تثكل تلك الرؤية. 
وقد أظهرت نتائج الدراسة أن هذه الرؤى- وقد احتلت مساحة لا بأس بها من القصيدة لديه- لا تعدو أن تكون مجالا رحبا للتعريف بنفسه وإلقاء الضوء عليها من خلال الفخر بشعره، أو مجالا خصبا لصوغ المفاهيم النقدية الخاصة عن الفن الثعري والكثف عن النموذج الأمثل للشاعر الذي ماء يريد أن يبذ أقرانه، كما أن بعضها جاء في شكل وصايا شعرية أراد البارودي أن يزجيها للشعراء المعاصرين له، كذلك لا نعدم أن نجد بعضها أشبه بالبيان الثعري الذي يصوغ المبادئ الأساسية لفن الثعر، وأخرى أشبه بالإشارات المكرورة داخل قصائده مما يدخل في باب الثعر الثارح. الكلمات المفتاحية: محمود سامي البارودي، الشعر، النقد، رؤى. 
Al-Baroudi's Critical Views from his Poetry

\section{Mahmoud Sobhy Sayed Ahmed Shahin}

Department of Arabic Language, College of Arts and Sciences at Tabrjal, Jouf University, Saudi Arabia.

Department of Literature and Criticism, Faculty of Arabic Language in Menoufia, Al-Azhar University, Egypt.

Email: $\underline{\text { drmahmoud } \vee \varepsilon \cdot @ g m a i l . c o m ~}$

\section{Abstract:}

The present study aims to highlight Al-Baroudi's critical views through his poems which are almost unknown; scholars who have examined Al-Baroudi's poems in previous studies have focused on his poems through which he became widely known as a poet, illuminating themes and figures of speech. They have not highlighted his several critical views embedded in his poetry with the exception of very few quick remarks.

Therefore, reading Al-Baroudi's poetry and identifying the lines and poems expressing all his critical views on poetry in one study is a new and unusual endeavor foregrounding this area which $-\mathrm{I}$ believe- has not been trodden before.

Conclusions of the present study show that these views that cover a fair amount of his poetry- can be regarded as an adequate account for introducing himself through praising his poetry. In addition, they can be considered as a proper place for drafting his critical concepts on poetic art or for the ideal model of the poet who wish to surpass his fellow poets. Some of his views represent poetic advice to his contemporary poets. Some of them are similar to poetic statements formulating the basic 
principles of poetic art; others are akin to repeated indications in his poems which are subsumed under the poetic commentary.

The present study adopts a descriptive approach through which Al-Baroudi's embedded views in the five sections are identified. In addition to the descriptive approach, the aesthetic approach is often employed to analyze a certain lexical item related to a view in a specific line or a group of lines representing this view.

Keywords: Mahmoud Sami Al-Baroudi , poetry, criticism, views. 


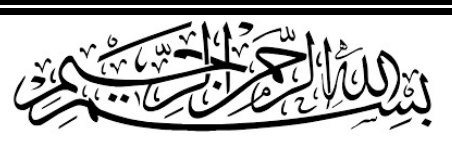

$$
\text { تقديم }
$$

الحمد الله رب العالمين، والصلاة والسلام على أشرف المرسلين، سيدنا محمد وعلى آل بيته الأطهار وصحابته الأخيار، ومن تبعهم بإحسان إلى لى

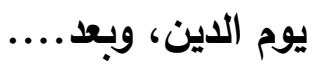

فإن اشتغال الثاعر بالنقد من الأمور التي دونتها الكتب الأدبية والمصادر النقدية قديما وحديثا، حتى أضحى ذلك ميدانا خصبا رحبا لكثير من الدراسات والأطروحات والبحوث الأكاديمية، التي لم تأل جهدا- على الرغم من تباينها في المعالجات- في إبراز دور الثاعر في تثرية الخطاب النقدي ورفده بالرؤى النقدية؛ ومن هنا كان سبب اختياري موضوع (رؤى البارودي النقدية من شعره) إذ الرؤية هنا تعد فكرا تبناه الثاعر وصرح به في شعره، بخلاف القضية التي تحتاج إلى أدلة وبراهين وحجج، وتصنف الآراء إزاءها إلى فريقين، ليتم قبول ما يتم الرضا عنه والميل إليه، ومن ثم كان إيثار

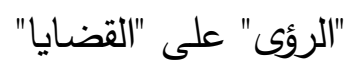

وقبل أن أدلف إلى موضوع البحث أبادر إلى القول بأنني في غير حاجة إلى إلقـاء الضـوه على ترجمـة للبـارودي، وإماطــة اللثام عـن حيـاة عصـره فقـد

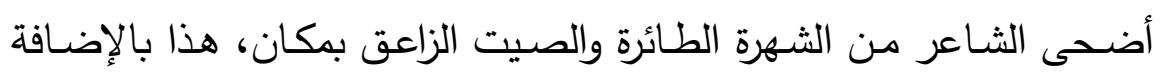
إلى ما سطره من شعر محكم، بعث بـه مجد العروبـة ونشر من خلاله حلل البيان القديم، ومن ثم رأيت أن العزوف عن ترجمته قد يكون أقوم قيلا؛ إذ دئ دئ التعرض لها يعد ضربا من التكثر الذي لا جدوى من ورائه. 
وتأتي أهمية هذه الدراسة في تجليتها بعدا يكاد يكون مطمورا لدى البارودي، خاصـة أن من تناولوا البارودي في دراسات سابقة تناولوه من خـلال منجزه الثعري الذي عرف بـه شـاعرا، مستظهرين منـه الأغراض ومـا يتخللها من فنيات، ولم يشيروا إلى ما لديه من رؤى نقدية عديدة بثها في شعره، باستثناء بعض الإشارات الخواطف التي تكاد تكون قبسة العجلان أو نهلة الظمآن، مثلما أشار "العقاد" في كتابه (شعراء مصر وبيئاتهم في الجيل الماضي)(")

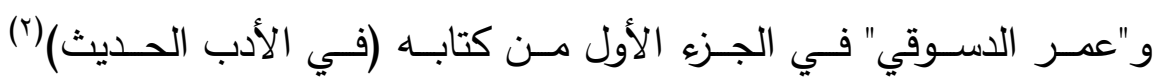
والدكتور / "شوقي ضيف" في كتابه (لبارودي رائد الشعر الحديث)(r)" ومن ثم فإن قراءة شعر البارودي واستخراج الأبيات والقصـائد التي تشكل مجموع رؤاه النقدية حول الثعر في ضميمة واحدة يعد تغريدا خارج السرب، وإبرازا لهذا الجانب الذي أراه - من وجهة نظري- غير مطروق من قبل. وقد رصدت هذه الدراسة بعض الطروحات التي تشكل بعض القضايا النقدية من البارودي من شعره، والتي وقعت في خمسة مباحث، كل مبحث يحمل رؤية نقدية على النحو الآتي:

المبحث الأول: الشعر بين الطبع والصنعة. المبحث الثاني: خلود الشعر لصاحبه بعد موته. المبحث الثالث: التفوق على الآخر. المبحث الرابع: أوصاف "الثعر" القصيدة.

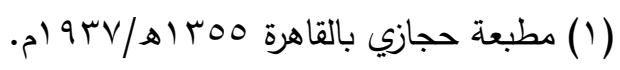

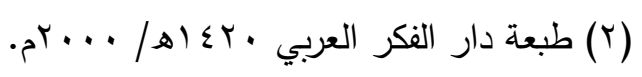

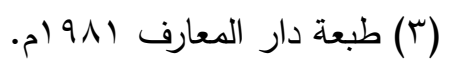


المبحث الخامس: وظيفة الشعر .

وقد وقعت هذه المباحث مسبوقة بمقدمة وتمهيد رصدت فيه جدلية الثاعر الناقد والناقد الثاعر ، ثم ما تقدم هذه الدراسة من دراسات سابقة عن الشعراء

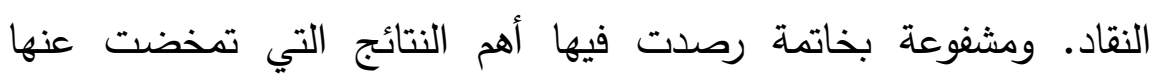
الدراسة.

والحق أنـي قيدت الموضـوع بـرؤى البـارودي النقديـة من شعره، حتى نبعد الجانب النقدي الذي أودعه مقدمة ديوانه الثعري، إذ تكفل بدراسة هذا البعد بـدي

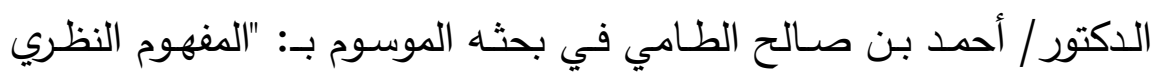

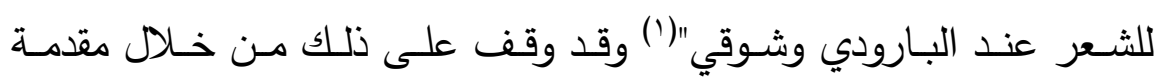
البارودي لديوانه، وكذا مقدمة شوقي لديوانه.

وبعد فإن كنت قد وفقت في هذه الدراسة فالفضل الله وحده، وإن كانت الأخرى فحسبي أني بلغت بنفسي عذرها، "ومبلغ نفس عذرها مثل منجح" والله أسـأل أن يجعل هذا العمل خالصـا لوجهه الكريم وأن يجعله في ميزان حسنات والدي رحمه الله تعالى، والله من وراء القصد، وهو الهادي إلى سواء السبيل.

(1) بحث منشور بكلية الآداب جامعة الملك سعود - المجلد ب ا- عدد ا - سنة | .. 


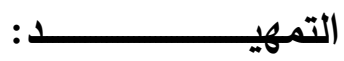

\section{أولا: جدلية الشا عر الناقد والناقد الشاعر :}

غير خاف أن ثمة علاقة حميمة وأصرة وطيدة بين الثاعر وشعره، تلك التي

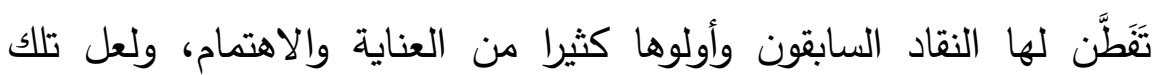
العناية وذلك الاهتمام جعلهم ينقسمون إزاءها أفرقة لا تتدابر ولا تتثاذر بل

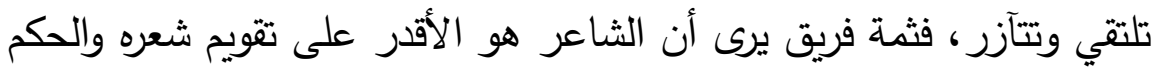

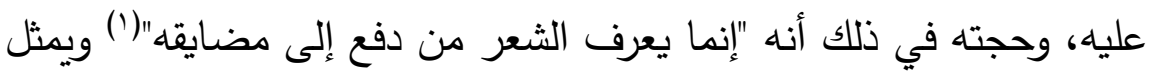
هذا الفريق بشار بن برد وأبو نواس والبحتري والمتنتبي.

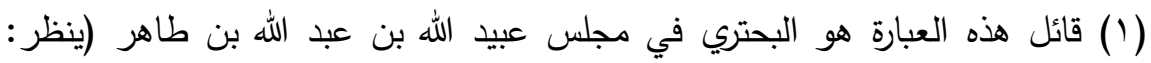

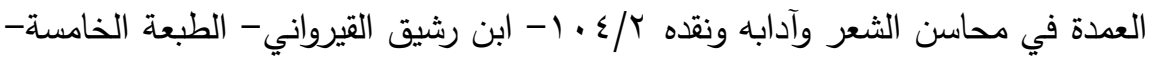

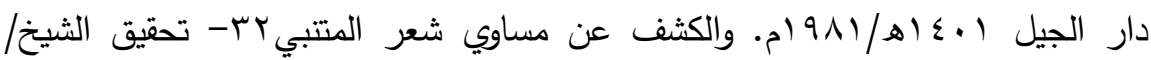

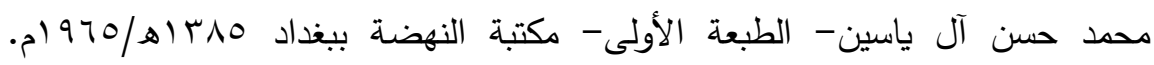

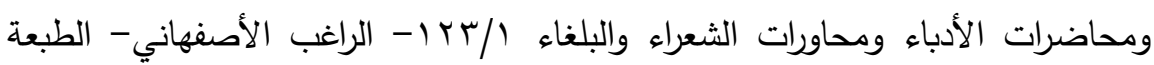

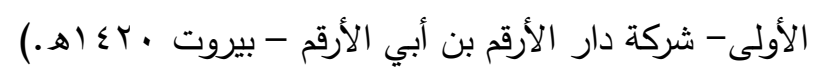

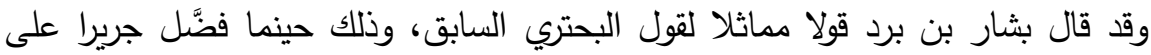

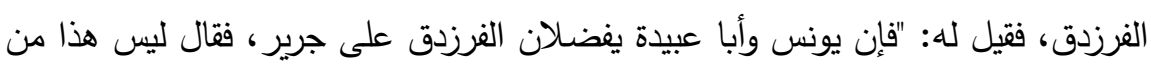

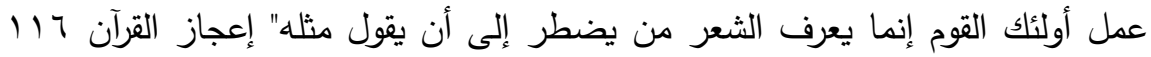

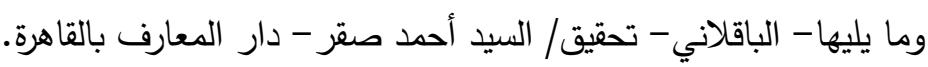
وكللك نجد قولا للمتببي يقترب من القولين السابقين، وذلك حينما نقد سيف الداني الدولة

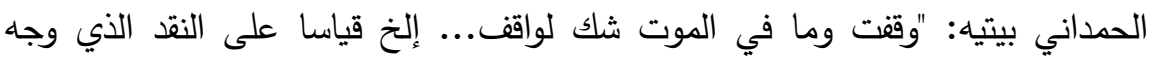

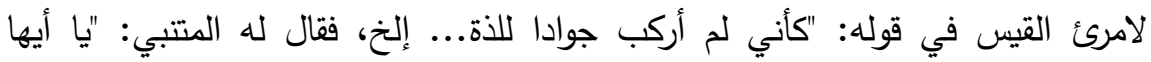

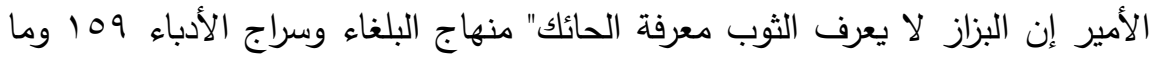
يليها - تحقيق/ محمد الحبيب بن الخوجة- دار الغرب الإسلامي د.ت التراء). 
وثمة فريق ثان نظر إلى الثاعر على أنه تابع للناقد، وإلى الناقد على أنه قاض صيرفي في الحركة الشعرية ، ويمثل هذا الفريق في نقدنا العربي القديم

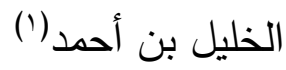

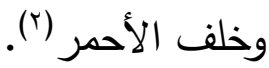
وثمة فريق ثالث يسلم زمام العملية النقدية لأدباء النقاد(؟) كالجاحظ والحسن بن وهب ومحمد بن عبد الملك الزيات. والخلاصة في ذلك أن الثاعر أدرى الناس بشعره، وأعلم الناس بخيوطه وخطوطه؛ لأنه المبدع الحقيقي للنص، وإيمانا منا بأن النص وجد قبل التأويل. أما الناقد لو امتلك مفاتيح الولوج إلى النص ليضعه على محكات لئ لهات الجودة والرداءة أو مجسات القوة والضعف أو يجوس خلاله محلال ومفسرا، فإن ذلك رهن بثقافته، ومن ثم يتقاطع جزئيا أو كليا مع الثاعر وقد لا يتماس، هذا بالإضافة إلى أن الثاعر قد يخمل من يجابهه من النقاد برأيه،

(1) ورد أن الخليل بن أحمد قال للشاعر بن مناذر : "إنما أنتم معشر الشعراء تبع لي وأنا

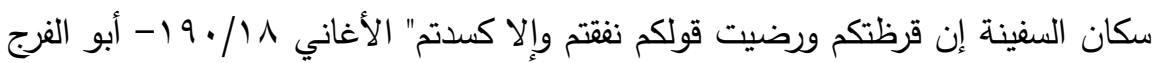
الأصفهاني- تحقيق/سمير جابر - الطبعة الثانية- دار الفكر بيروت.

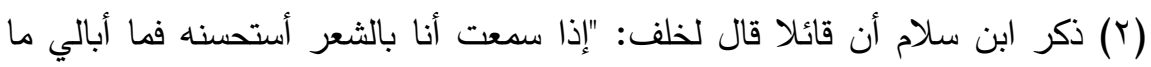

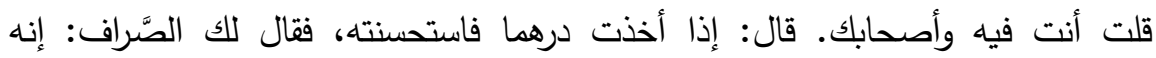

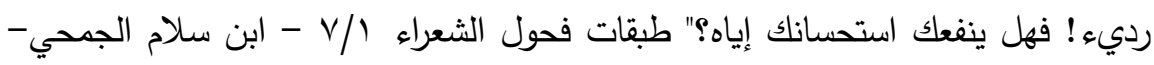
تحقيق/ محمود محمد شاكر - دار المدني - جدة. (r) فقد ورد في العمدة قول الجاحظ: "طلبت علم الثعر عند الأصمعي فوجدته لا يحسن إلا غريبه فرجعت إلى الأخفش فوجدته لا يتقن إلا إعرابه، فعطفت على الجى أبي عبل عبيدة

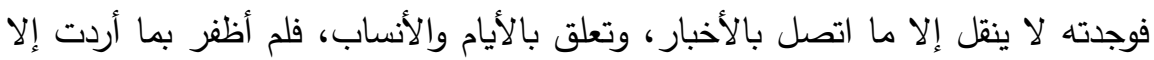

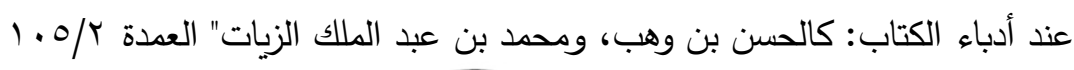


ليكون ما قاله الثاعر أوعى من فهم القارئ أو الناقد، وإلا فبم نفسر ردّّ بشار بن برد على خلف الأحمر حينما أنثد الأول: [من الخفيف](').

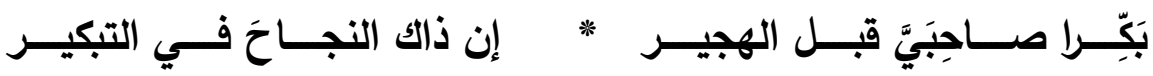

فقال لله الثاني "خَلَفُ": "لو قلت يا أبا معاذ مكانَ: " إن ذاك النجاحَ في

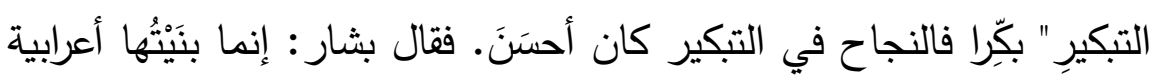

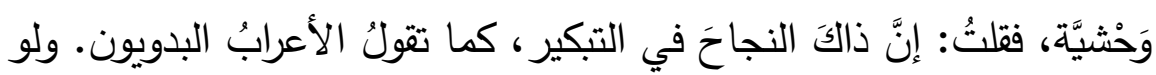

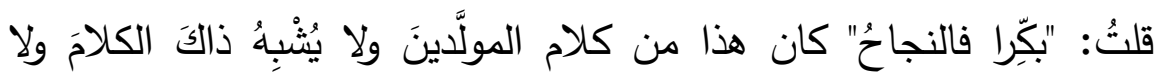

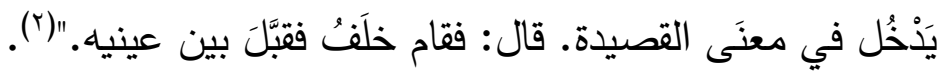
ولا يخفى كذلك ما كان يتمتع به بشار من ذائقة نقدية في توجيه الكلام أو

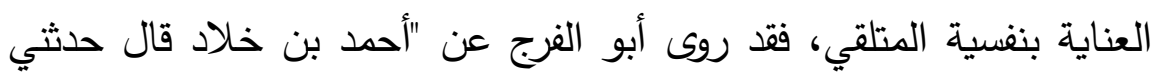

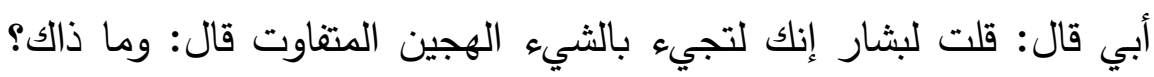

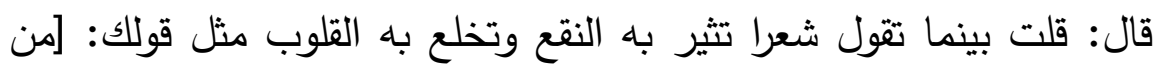

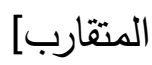

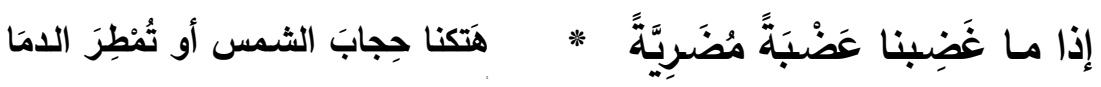

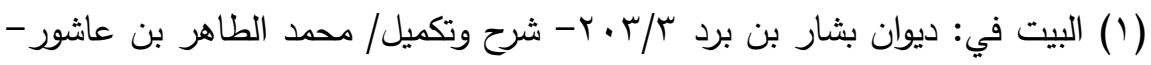

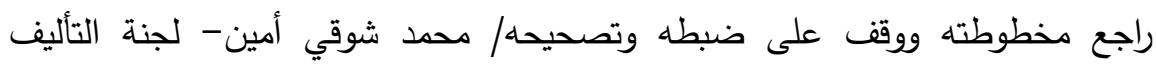

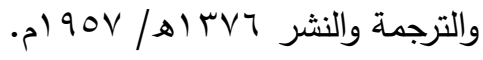

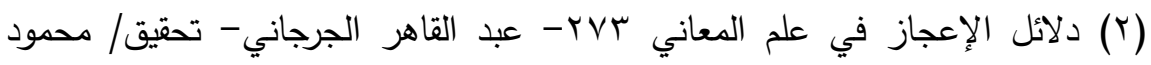

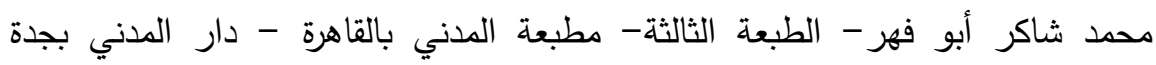

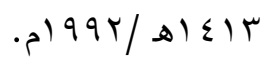




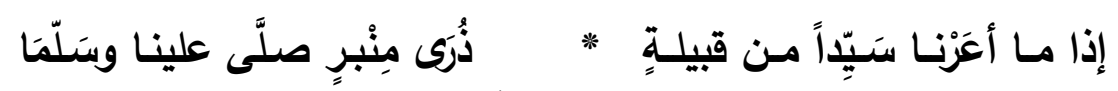

تقول: [من الهزج]

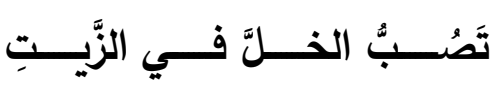

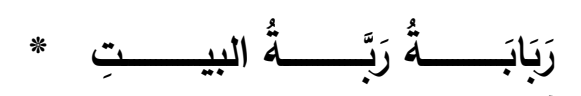

ودِيــــُ حَسَـــنُ الصّــــوتِ

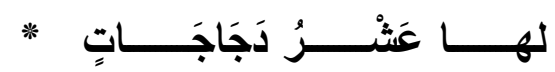

فقال: لكل وجه وموضع، فالقول الأول جد، وهذا قلته في ربابة جاريتي وأنا

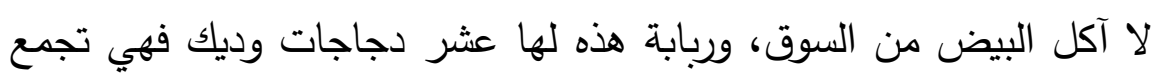

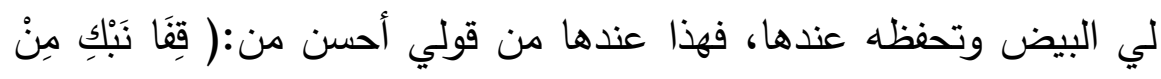

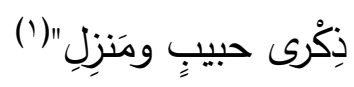

كذلك ما كان نقد طرفة بن العبد وهو الثاعر الفحل، للمتلمس أو للمسيب بن علس، حينما قال: [من الطويل]

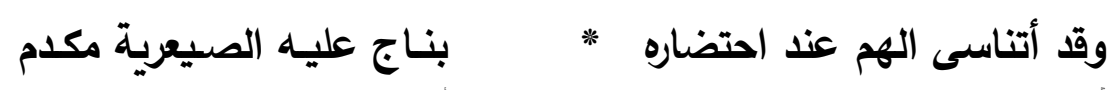

فقال له طرفة: استتوق الجمل، أي وصفت الجمل بوصف الناقة؛ لأن

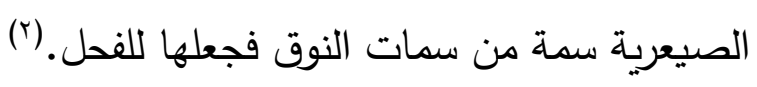
وغير ذلك كثير مما تستبحر به كتب النقد الأدبي مما أراني في غير حاجة إلى ذكره منعا للتكثر في ذلك الأمر الذي لا يحتاج دليلا لإثباته.

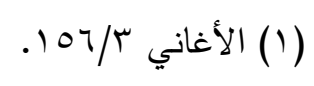

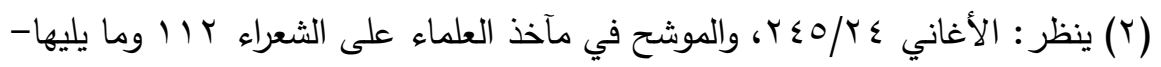

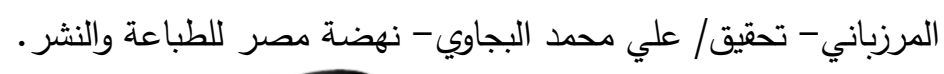




\section{ثانيا: الدراسات السابقة:}

إن نقد الثعر شعرا من أنماط النقد التي مارسها لفيف من الشعراء قديما وحديثا، وهذا مما دفع معظم الدارسين والباحثين لاشتغالهم بقضية (الثاعر ناقدا) والوقوف على المنجز الثعري للشاعر لاستظهار رؤاه النقدية منه، ومن ثم صار لهذه القضية أو إن شئت قل الجدلية حضورها الطاغي على أسلة كتابنا من النقدة في العصر الحديث، فقد أفردوا لذلك كتبا وبحوثا تعنى بهذه الجدلية عساها أن تضع الأمر في نصابه، وأن تجعل لكل طعام أكلة. ومن ذلك على سبيل المثال: - مئ

(أ) : الثغعراء نـقادا للدكتور عبد الهبار المطلبي (') إذ بسط فيه المؤلف القول حول كثير من القضايا النقدية التي تطرق إليها الثعراء العرب في العصرين الإسلامي والأموي، مثل دواعي الثعر، ووظيفة الشعر، وتهذيب الشعر، والصدق الثعري، والإلهام، وتصوير الشعر لخبايا النفس، والفصل بين الثعراء.

(ب) : كتناب مغاهيهم نقدية لربنيه وبليك(r) إذ عرض في الفصل الثالث عشر منه والموسوم بـ "الثاعر ناقدا، والناقد شاعرا والثاعر الناقد" عددا من الأعمال الشعرية التي تمثل (النقد المنظوم) في الآداب الأوربية، وخص بالذكر منها قصيدة ( بوب مقالة في النقد) لأنها "تظهر قدرا من المزايا الجمالية كالتصميم والمهارة في استعمال الوزن والبراعة اللغوية"(؟)

$$
\text { (1) الطبعة الأولى- دار الثئون الثقافية العامة- بغداد- ب1919 ام. }
$$

ترجمة/ محمد عصفور - عالم المعرفة- نشر المجلس الوطني للثقافة والفنون

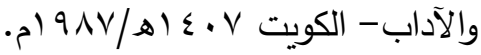

$$
\begin{aligned}
& \text { مفاهيم نقدية } 0 \text { ؛ r. }
\end{aligned}
$$


وانتهى إلى أن بعض الثعراء في الغرب ظلوا "يحاولون التحدث في شعرهم عن الشعر والثعراء: أي أن يخلقوا شيئا سمي الثعر الحديث عن الثعر فئر meta- poetry الذي يتحدث عن الثعر بتحديد هوية الثاعر ووظيفته ورسالته"('). واستظهر عنه أن الثاعر عمل "عبر التاريخ على تضخيم صورته، وعلى وصف رسالته لتهن هويه وإبراز دوره والدفاع عن نشاطه، وتكلم خيرا أو شرا عن رفاقه الشعراء - شعرا بوصفه شاعرا، ونثرا أيضا، كناقد أو كواحد من عامة الناس، لله آراؤه

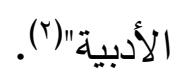

\section{(م) : قضية الشاعر الناقد- الناقد الشاعر - الثناعر والنقد: دراسة} في النقد القديم، 1قاسم المومنيه(r). تلك القضية أو الجدلية التي خلص فيها إلى "أن الثعر عند الشاعر الناقد هو الأساس، وكل ما سواه ففضلة، تماما كما أن النقد عند الناقد الثاعر هو الأساس وكل ما سواه فنافلة"(؛). وذهب إلى أن اتحاد الثاعر بالناقد اتحاد قلق، ومثل هذا الاتحاد لا يعود

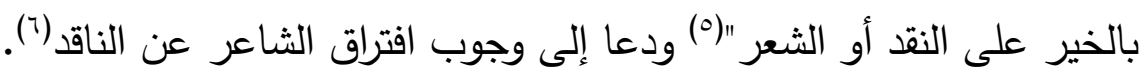

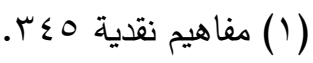

(r)

بحث منشور في مجلة جامعة دمشق في العلوم الإنسانية- المجلد ه- العدد 9 1-

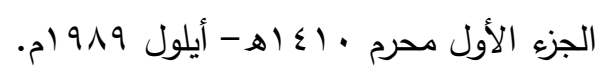

(ع) قضية الثاعر الناقد-الناقد الثاعر - الثاعر والنقد: دراسة في النقد القديم V^.

( ) ذاته

( ) ذاته 9 ( ) 
(د) : ابـن الرومي ناقدا، لجاسر خليل سالم أبو صفية (') ـ إذ جمع الباحث

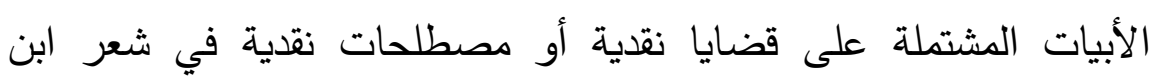
الرومي؛ لييرز الجانب الآخر لاى الثاعر وهو الجانب النقدي. (هـ) : رؤية أبيى تمام للشعر من خلال ديوانه، لـ"مصطفى صسين محمد عناية"(؟). وفيه قام الباحث برصد رؤية أبي تمام للشعر من خلال وصفه دائه

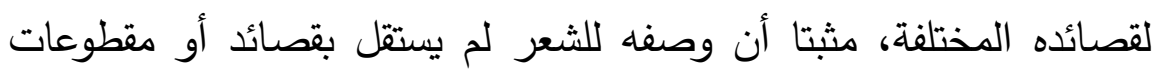
خاصة، وإنما جاء هذا الوصف في خاتمة القصيدة. (و) : رؤى الشاعر الشعريته قراءة نقدية في نصوص البحتري

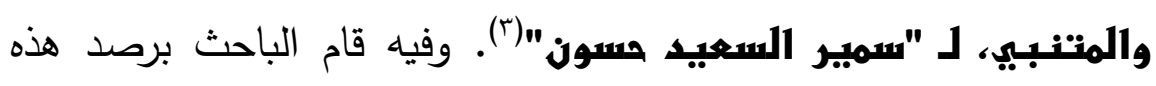
الرؤى في شعر الثاعريْن، وكان صنيعه صنيع البحث السابق.

(1) منشور بحوليات الآداب والعلوم الاجتماعية، مجلس النشر العلمي، جامعة الكويت،

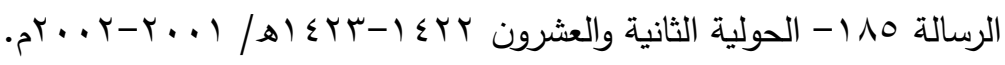

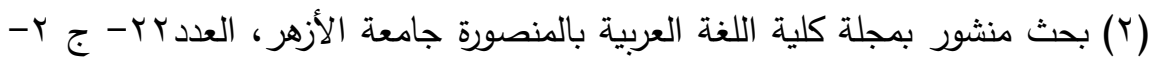
سنة r. ب Trم.

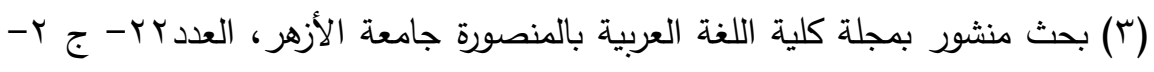

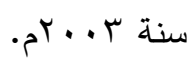




\section{المبـشث الأول: الشعر بين الطبـم والصنـعة:}

إن من يتملى شعر البارودي يدرك أن الرجل كان من المطبوعين على قول الشعر وفي الوقت نفسه هو شاعر صَنَاع يعكف على القصيدة حتى تستوي على سوقها، وهذا وذاك من خـلال الملفوظ الثـعري الذي بثه في كثير من

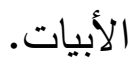

ولا يتوهمن أحد أن البـارودي ينـاقض نفسـه بارتداده إلى الطبع تـارة وإلى

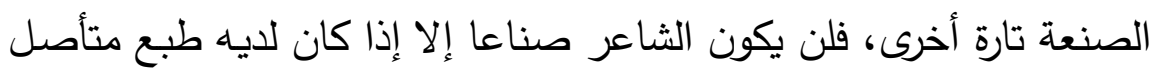
يسبق مرحلة الصنعة، ولو انتفت صفة الطبع لديه لما كان شاعرا، ولصـار في المرتبة الدون وإلا فما تفسير دن لقب بـ "الثويعر" في تاريخ الأدب؟ إن هذا اللقب يوحي بعدم الاعتراف بالشاعرية لصـاحبه في مواجهة الفحول من الثعراء، ومن أمثلة ذلك ما ذكره "الجاحظ" عمن يقال لـه "الثويعر" قائلا: "والشويعر مثل محمد بن حمران بن أبي حمران، سماه بذلك امرؤ القيس بن حجر • ومنهم من بني ضبة: المفوف، شاعر بني حميس...والثويعر أيضـا

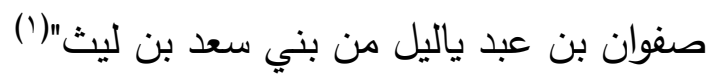

فالمرو لو ارتضع أفاويق الثقافات والعلوم والفنون على أنواعها ولم يكن شاعراً أصلاً، لما أمكنه أن يحصل على لقب شاعر؛ لأن الثقافات والعلوم والفنون، على جلال قدرها لا تصنع شاعراً، وإنما تساعد في صنعه. فالثاعر تصنعه أولاً فطرة مستعدة موارة بالرؤى، لها صلات غير قابلة للشرح مع عوالم غير

(1) البيان والتبيين / / إ - الجاحظ- تحقيق وشرح/ عبد السـلام هارون- تقديم د/

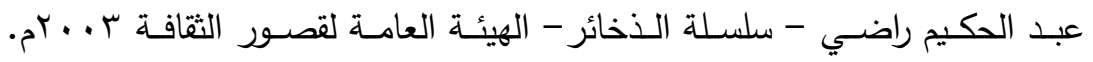

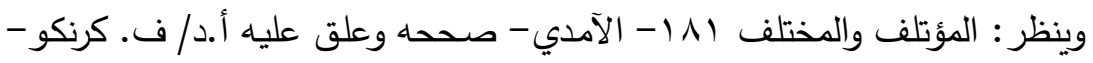

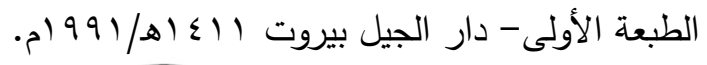


منظورة. ولكن حتى مثل هذه الفطرة لا تكفي وحدها لصنع شاعر عظيم ما لم ترفدها الثقافة.

فحينما يقول البارودي:[(من الطويل](')

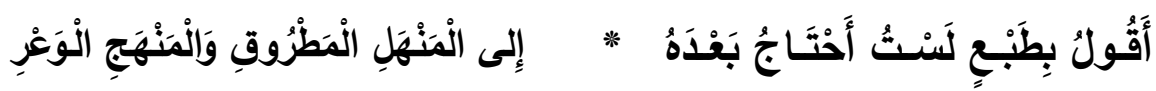

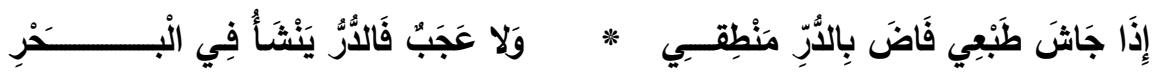
يثير إلى أنه مطبوعُ على قول الشعر ، لا يتكلف في نظمه ولا يتعسف في رصفه, بل يتدفق الثعر على لسانه كما يتصبب الماء من عل إلى منحدر في هوادة وطواعية دون تعسف أو اقتسار . وقد أشار إلى طبعه أستاذه الثيخ "المرصفي" حين قال: "هذا الأمير الجليل ذو الثـرف الأصـيل والطبـع البـالغ نقـاؤه، والذهن المتتـاهى ذكـاؤه، محمـود سامي البارودي، لم يقرأ كتابا في فن من فنون العربية غير أنه لما بلغ سن التعقل وجد من طبعه ميلا إلى قراءة الشعر وعمله، فكان يستمع بعض من لـه درايـة وهو يقرأ بعض الدواوين أو يقرأ بحضـرته حتى تصـور في برهـة يسيرة هيئات التراكيب العربية ومواقع المرفوعات والمنصوبات والمخفوضـات

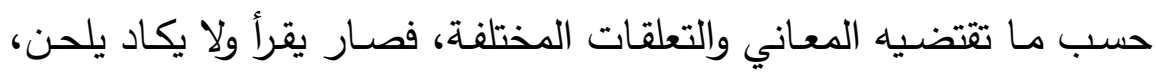
وسمعته يسكن ياء المنقوص والفعل المعتل بها المنصـوبين، فقلت لـه في

(1) ديوان البارودي ץ. ·ץ- حققه وضبطه وشرحه/ علي الجارم، ومحمد شفيق معروفدار العودة ببيروت 991 ام. 


\section{العدد الحادي و الثلاثون}

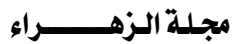

ذلك، فقال هو كذا في قول فلان، وأنشد شعرا لبعض العرب، فقلت لـه تلك ضرورة وقال علماء العربية إنها غير شاذة"(1) .

وفي كلام "المرصفي" ما يشير إلى أن البارودي انتهج لنفسه منهجا لاحبا يرتد إلى طريقة الرواية التي كان يتلقنها الثعراء القدماء- أو بمعنى آخر إنر

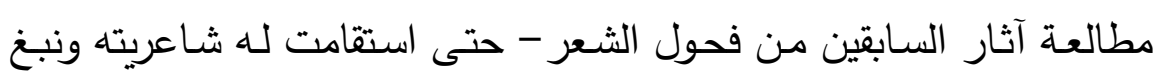
فيها هذا النبوغ. فالراوية يبدأ هاويا ثم يصير شاعرا خنذيذا؛ لأن روايته ترفد موهبتـه وتصـقلها، وكأنـهـ جمـع بـين الحسـنيين الموهبـة الفطريـة والمـوروث المكتسب، وهما كفيلان على تقديم شـاعر يحمل مدونـة تشهـ لـه بالفوقيـة والتبريز •

والحـق أن "المرصـفي" أراد أن يـدلل بصـنيع البـارودي على نجـاح المـنهج

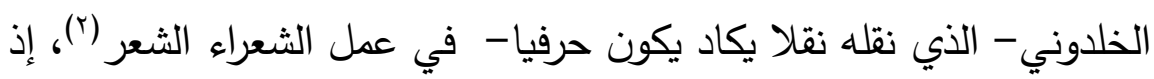
يقول ابن خلدون: "اعلم أن لعمل الثـعر وإحكام صـناعته شروطاً، أولها: الحفظ من جنسـه أي من جنس شعر العرب، حتى تتشـأ في النفس ملكـة ينسج على منوالها، ويتخير المحفوظ من الحر النقي الكثير الأساليب. وهذا المحفوظ المختار أقل ما يكفي فيه شعر شاعر من الفحول الإسـلاميين، مثل ابـن أبـي ربيعـة وكثير وذي الرمــة وجريـر وأبـي نـواس وحبيـب والبحتري

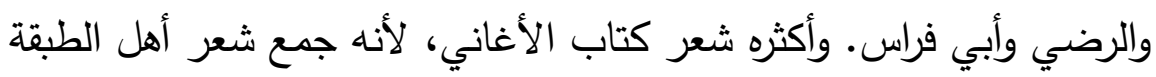

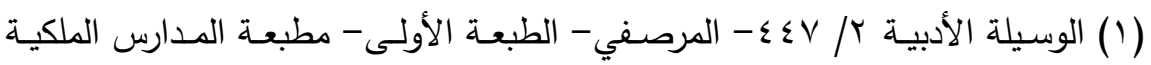

بدرب الجماميز بالقاهرة بو I I.

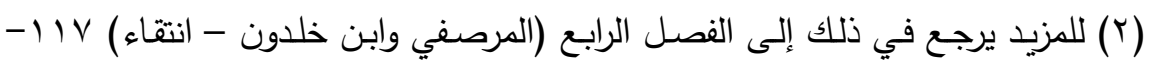

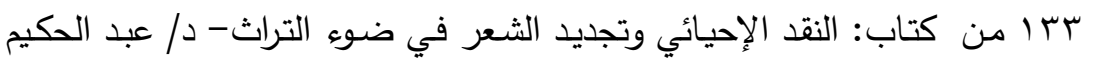

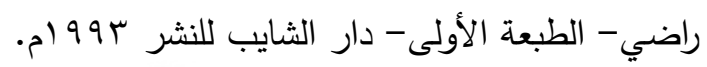


الإسلامية كله، والمختار من شعر الجاهلية. ومن كان خالياً من المحفوظ

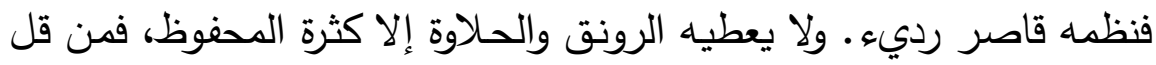

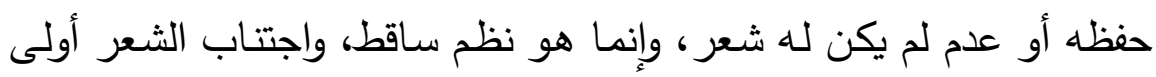
مدن لم يكن له محفوظ. ثم بعد الامتلاء من الحفظ وشحذ القريحة للنستج

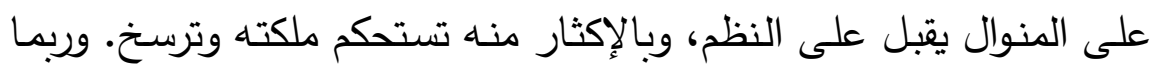

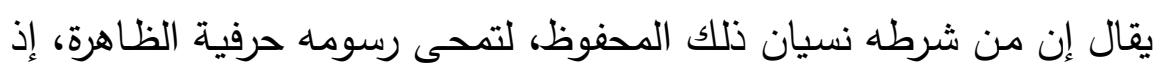

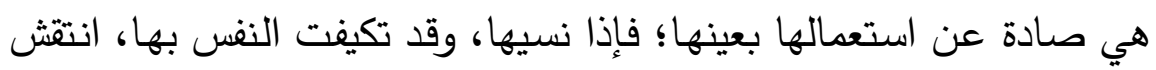

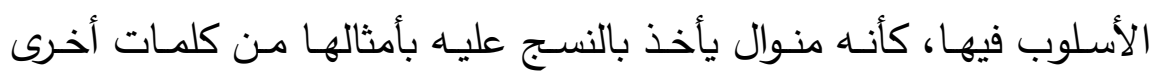

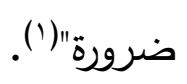

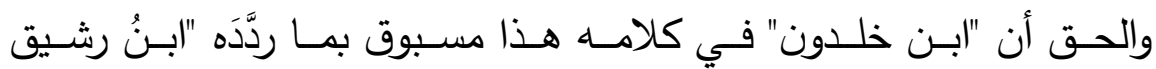

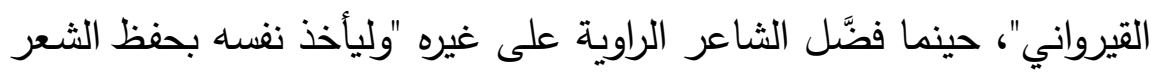

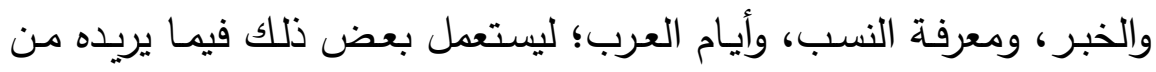

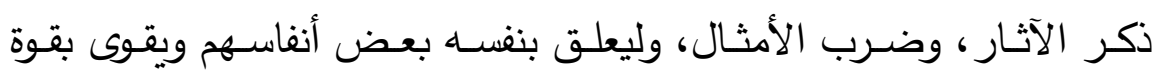

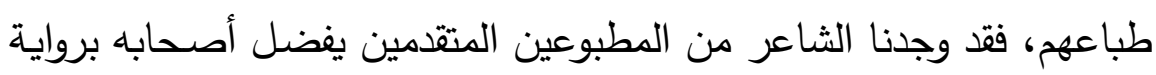

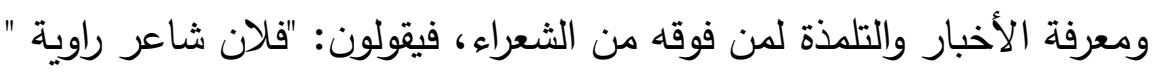

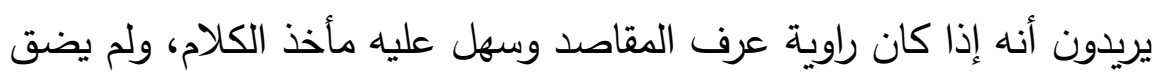

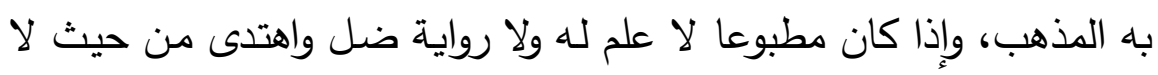

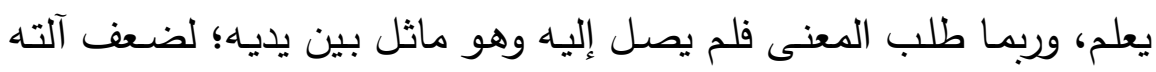

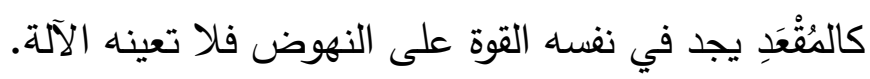

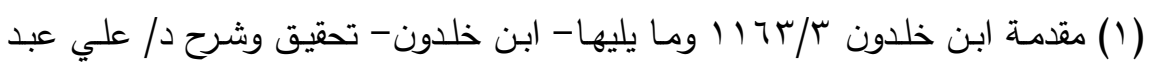

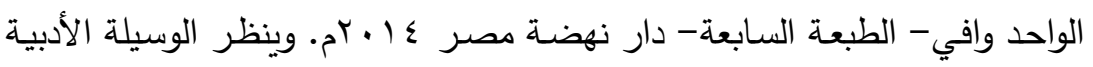
. 
وقد سئل "رؤبة بن العجاج" عن الفحل من الثعراء فقال: هو الراوية، يريد أنه إذا روى استقحل. - إن.

قال "يونس بن حبيب": وإنما ذلك لأنه يجمع إلى جيد شعره معرفة جيد غيره فلا يحمل نفسه إلا على بصيرة. وقال "رؤبة" في صفة شاعر :

لقد خشـيت أن تكون سـاحرا راوبـــــة مـــــرا ومــــرا شـــــاعرا فاستعظم حاله حتى قرنها بالسحر •

وقال "الأصمعي: "لا يصير الشاعر في قريض الشعر فحلا حتى يروي

أشعار العرب ويسمع الأخبار ويعرف المعاني وتدور في مسامعه الألفاظ"('). ومن هنا كان الكثيرون من الشعراء الفحول - قديما - رواة لشعراء سابقين أو معاصرين لهم، ومن يردد البصر في أعطاف الشعر القديم وتضاعيفه يدرك حقيقة ذلك لا محالة، فكان الأعشى راوية خاله المسيب بن علس(؟)، وكان زهير بن أبي سلمى راوية لزوج أمه أوس بن حجر (r)، كما كان راوية

| () العدة في محاسن الثعر وآدابه ونقده- 19V/1. r () الموشح 01

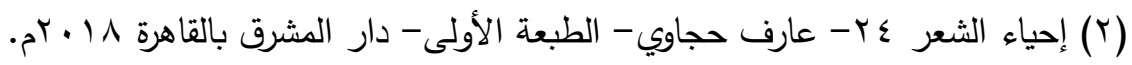

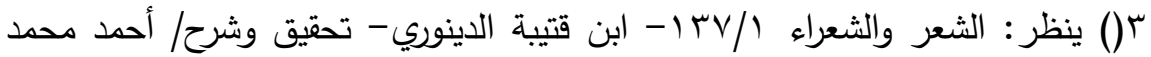

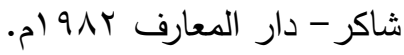


لخاله بشامة بن الغدير (')، وراوية أيضا للطفيل الغنوي(؟) ، وروى لزهير ابنه كعب والحطيئة، وروى لكعب الحطيئة، وروى للحطيئة أكثر من راو أشهرهم

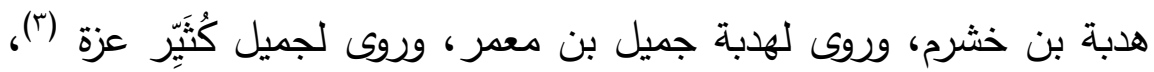
وهكذا.

والبارودي نفسه- في شعره- يقر بترسمه آثار سابقيه من الشعراء القدامى في العصر العباسي، والسير على منوالهم، من أمثال أبي نواس ومسلم بن

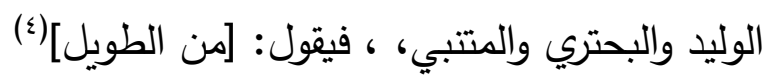

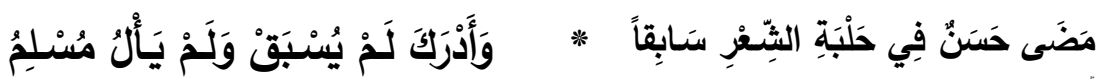

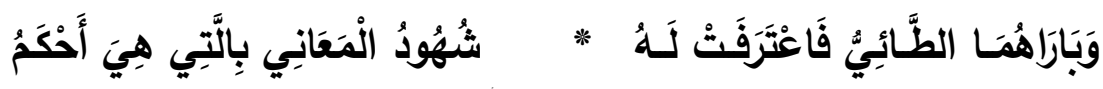

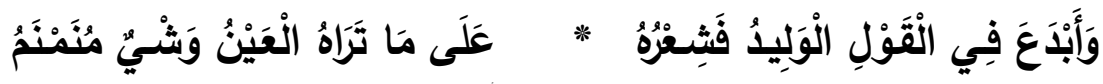

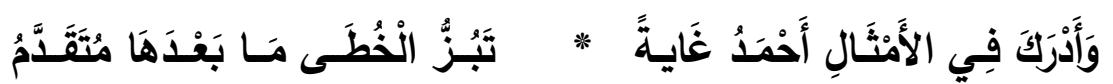

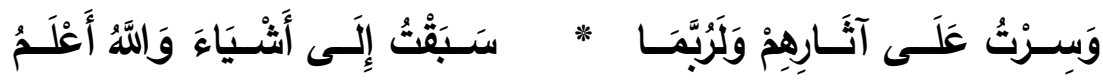

() ينظر : شرح المعلقات السبع VYr ا-الزَّْزَني- الطبعة الأولى- دار احياء التراث

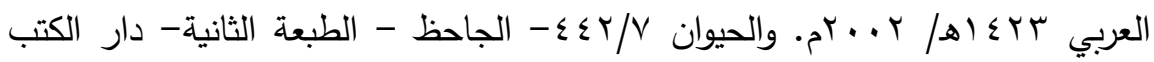

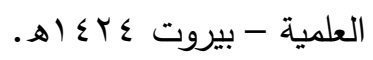

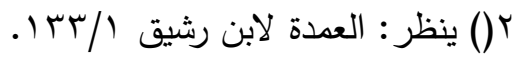

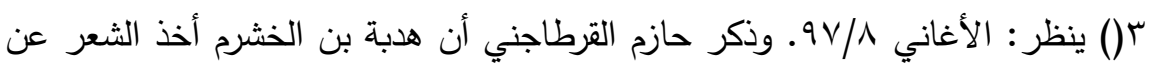
بشر بن أبي خازم. (ينظر : منهاج البلغاء وسراج الأدباء بV (YV).

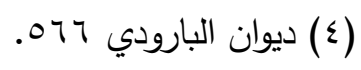


وغيـر خـاف أن البـارودي بتعـداده أســاء الثـعراء الـذين مضـى على سكيكتهم ونستج على منوالهم لم يكن بدعا من الثعراء، بل يذكرنا بصنيع

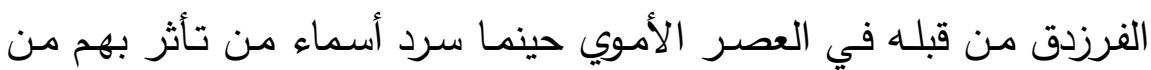

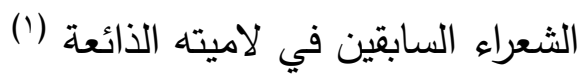
كذلك كان العقاد واحدا من جملـة النقاد الذين أشـاروا إلى طبع البارودي، فقال: "فهو أول الثعراء المطبوعين في العصر الحديث، ولعلـه أسبق ممن بعـده في قـوة الطبع التي أبـت لمقوماتـه "الثخصـية" إلا أن تظهـر خـلال

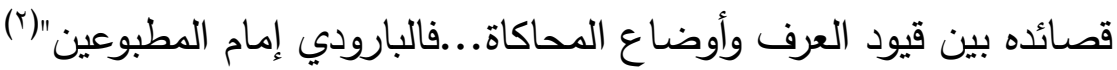
ثم يقول: "وليس عندنا ولا عند أحد من قارئي البارودي شك في سليقته

الثعرية التي لا يسهل إخفاؤها، ولا تحتاج إلى كثير من الشحذ والتتبيه"(؟) كذلك ذهب زكي نجيب محمود إلى أن البارودي في شعره يصدر عن طبع لا تكلف فيه أو طبع موهوب، فجاء نظمه مرتبا ترتيبا طبعيا وفق ما تتطلبه

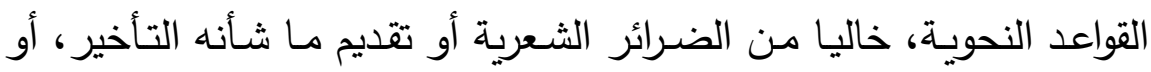
تأخير ما يستوجب التقديم. (؛)، كذلك رد الدكتور/ علي الحديدي(0) موهبته

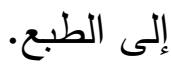

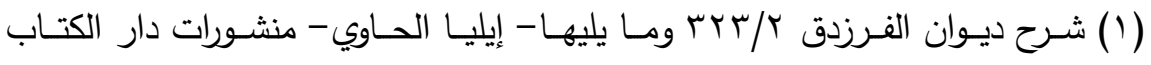

$$
\text { اللبناني - مكتبة المدرسة. }
$$

(Y) شعراء مصر وبيئاتهم في الجيل الماضي 0با إ وما يليها.

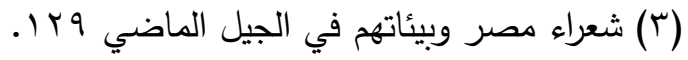

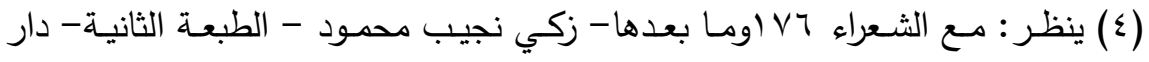

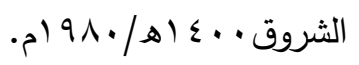

(0) ينظر : محمود سـامي البارودي شـاعر النهضــة سVب- دم/ علي الحديدي- الطبعة

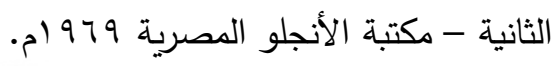


وما دمنا بصدد الحديث عن موهبة البارودي وطبعه فلا مناص من الحديث عن أمر ذي شابكة بالحديث عن الموهبة والطبع وهو الحديث عن الوراثة الثـعرية التـي لهـج بهـا البـارودي في قولـه: يقول البـارودي: [مـن الرمـل

(')

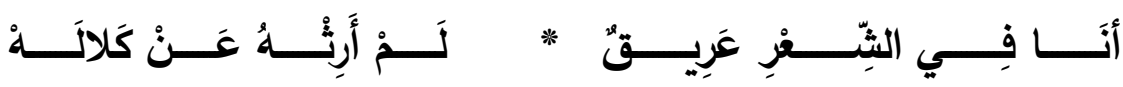

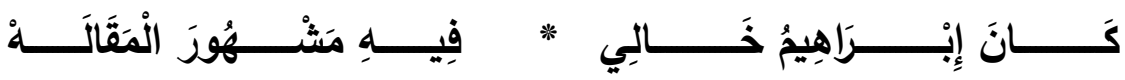

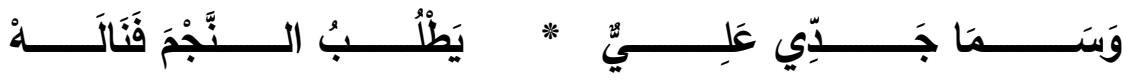

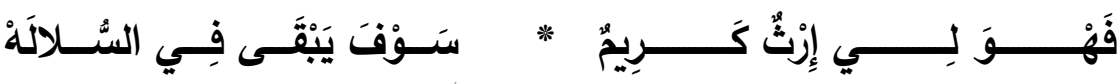
فنراه يشير إلى أن له أصولا ثابتة راسخة في الشعر ورث هذه الموهبة عنهم،

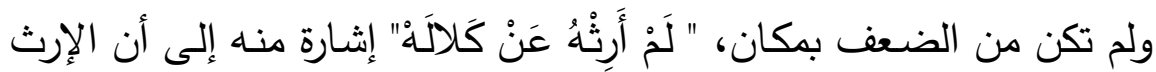
لم يكن عن طريق القرابة الضعيفة، لكن لا نظن أن خال البارودي (إبراهيم بن علي آغا البارودي) كان من الشعراء النابهين في عصره، وقد يحمل قول البارودي في البيت على أنه وجد فيه تشجيعا على قول الشعر كما وجد في الثي جده لأمه - علي آغا البارودي - المعالي التي يزهو بها.

ولعل استتناجنا يكون صحيحا إذا وضعنا كلمة "عريق" تلك التي أشار إليها الثاعر على الميزان النقدي؛ إذ يقول ابن رشيق: "وأما الشاعر ابن الثاعر 


\section{العدد الحادي و الثلاثون}

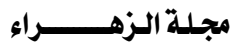

فقط فيقـال لـه الثنيـان... وهو كثير لـو أخذنا في ذكرهم لطالت مسـافة

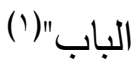

لذا اقتصر في بابه على ما سماه (بيوتات الشعر والمعرقين فيه) أي الأسر التي توارثت الشعر أبا عن جد، وما تجاوز الثلاثة أجيال يسميه "معرقا" أي ولي أن لهذه الأسرة أو السلالة عراقة متوالية غير منقطعة في قول الثاعر، كما يوضح ذلك بقوله: "والفرق بين المعرق وبين ذي البيت أن المعرق من تكرر الأمر فيه وفي أبيه وجده فصـاعداً، ولا يكون معرقاً حتى يكون الثالث فما

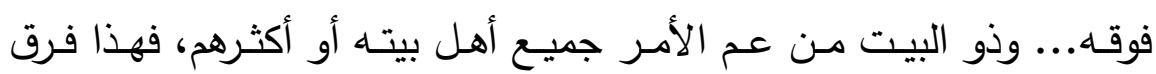

بينهما" (r) (بون

وما دمنا لم نعلم ذلك عن البارودي فكلامـه مردود إذا وضـع على المحكات النقدية، لكن هذا لا ينفي موهبته وسليقته وتعلقه بالثعر في صغره، على ما يفهم من قوله: [من الطويل] (r)

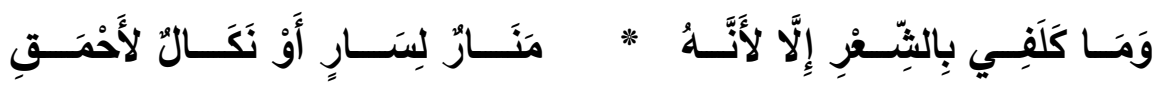

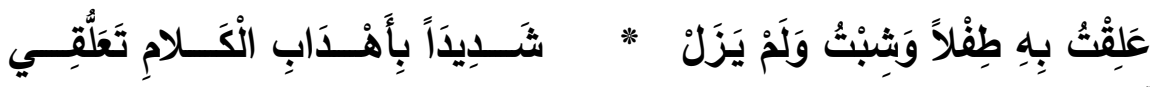
وعلى الرغم من قوة طبعه ووجود الموهبة لديه، فإنه كان يؤمن أن الثاعر لا يستحق هذا اللقب إلا إذا جود شعره وهذبه ونقحه وأعاد فيه النظر مرة بعد المـرة حتى تستوي القصـيدة على سـوقها، وشـأنه في ذلك شـأن كثير مـن

$$
\begin{aligned}
& \text { (1) العدة في محاسن الثعر وآدابه ونقده ك/ • •r. } \\
& \text { (r) ذاته }
\end{aligned}
$$

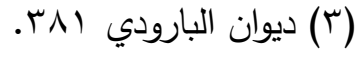


الثـعراء القدامى الذين يعرفون كيف يضـمنون لقصـائدهم الخلـود والذيوع، وذلك عن طريت تدخل العقل الواعي الذي يتمثل في عملية التهذيب أو التتقيح، والوقوف بأبيات القوافي بغية النظر فيها وتقويم ميلها وسنادها، حتى يصير أهلا لأن يتبوأ المرجعيةَ والتحكمَ في فن القريض، بل إن تلك العنايةُ التي تثـي بأهميـة الأداء الجمالي تحل صـاحبها مكانـة سـامقة متقدمـة بين الشعراء المجودين الذين اصطلح على تسميتهم شعراءَ مدرسةِ الصنعة الفنية أو عبيدَ الشعر، تلك المدرسةُ التي أسسها زهيرُ بنُ أبي سُلمى في العصر

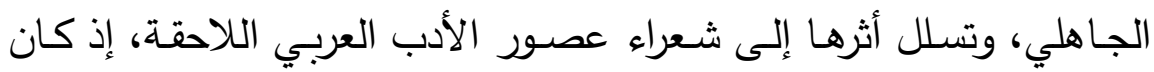
على الثـاعر حتى يحرز فوقية وتبريزا من أن يعيَ هذه الصنحَةَ ويلمَّ بها، قبل الولوج إلى عوالمهها، ومضايقها، كل ذلك في وجود موهبة فذة ولود وطبع أصـيل لـى الثـاعر ؛ إذ إن الموهبـة بمعزل عن الصـنعة لا تسـو بـص شعري يضـمن بقـاءه طـوِيلا في بؤرة التـداول القِرائسي، لأنَّ الموهبـة وحدها سرْعَانَ مَا تَنْفُ بواعثها وتنتهي صـلاحيتها وتقول ما عندها، بل إنها سرعان ما تختتق في مهدها.

يقول الرافعي في معرض الحديث عن البارودي وصبري: "وهما يشتركان معا في التلوم على صـنعة الشـعر والتأني في عمله، وتقليبهـ على وجـوه هـن

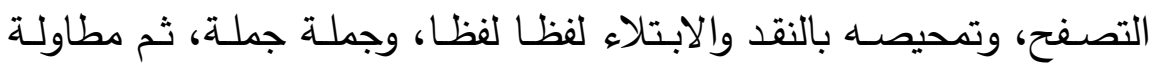

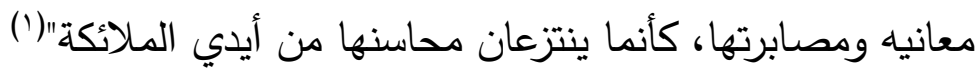

(1) مجلة المقتطف- العدد الخامس الصادر في امايو بr9 ام ، مقال بعنوان: "ثعر صبري" ص ror - مصطفى صادق الرافعي. 
وهذا الرأي لا يختلف عما قاله من قبل عن البارودي، إذ ذكر أنـه "شـاعر فحـل مجـود، وإن كـان ضـيق الفكر ضـــيف الحيــة في إبـراز المعـاني

$$
\text { واختراعها"( ) }
$$

وقد ذكر البارودي في مقدمته لايوانه أن خوفه من الزلل كان وراء تنقيحه الثعر، فقال: "فإن المرء وإن كثر إحسانه، لا يسلم من الزلة لسانه، وقَلَّ من

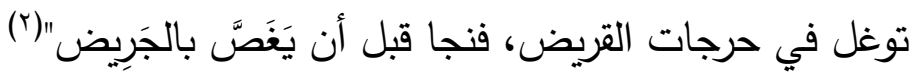
ومن ثم يقول البارودي: [من الكامل](؟)

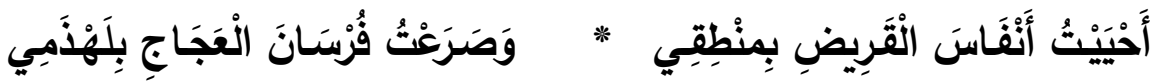

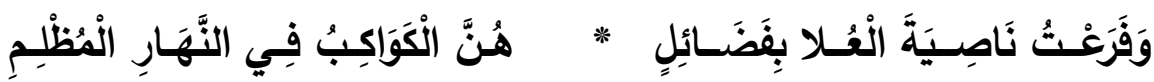

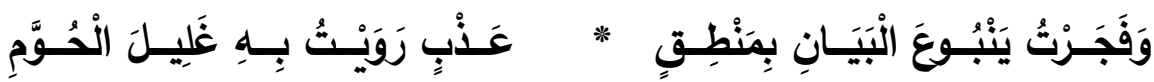

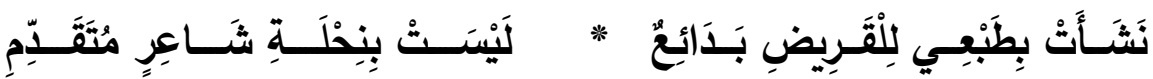

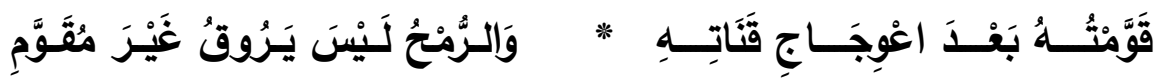

$$
\begin{aligned}
& \text { (1) رسائل الرافعي (ب- الدار العمرية (د.ت) } \\
& \text { (r) ديوان البارودي (المقدمة) هـ. }
\end{aligned}
$$

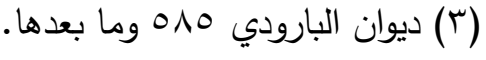




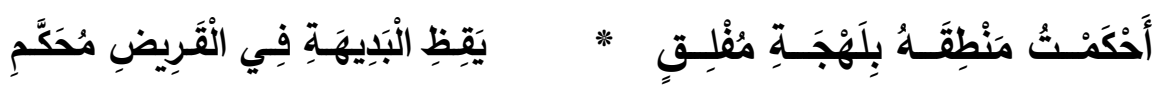

فقوله: "نثأت بطبعي للقريض بدائع" وقوله في البيت الأخير "يقظ البديهة"

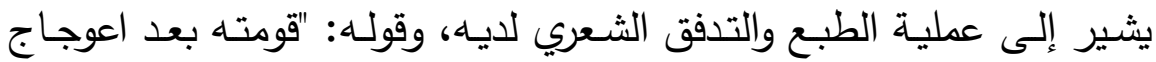

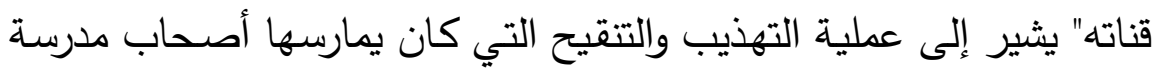

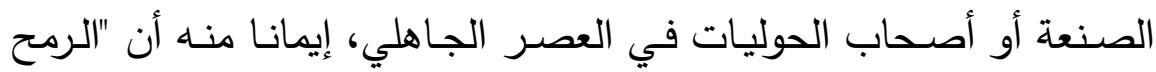

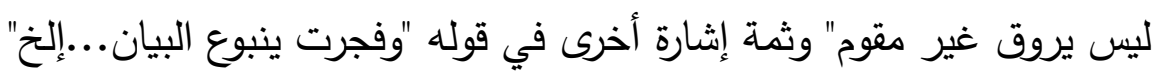

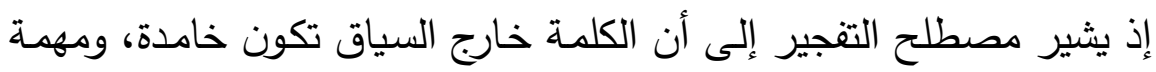

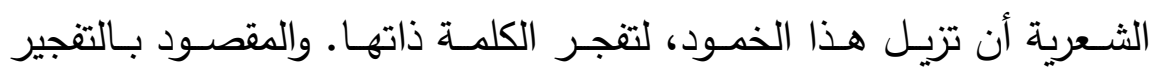
توظيف الكلمة في سياقات متعددة تكثف عن أبعادها الدلالية المباشرة وغير الكيل المباشرة، القريبة والبعيدة، يقول ابن ميادة: [من الطويل]

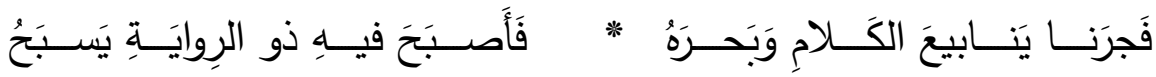

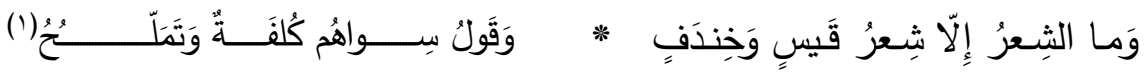
ولا أجانف الصواب إذا قلت إن الفعلين "أحييت" في البيت الأول، و"فرعت" في البيت الثاني، يرتبطان ارتباطا وثيقا بالفعل "فجرت" في البيت الثالث.

( (1) مفهوم الشعر في القول الثعري بr - دم/ محمد عبد المطلب- مجلة فصول - عدد

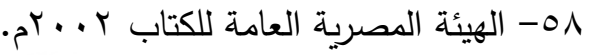


ولا يلبث في البيت الأخير أن يشير إلى إحكام القصيدة، تلك التي رددها في موضع آخر قائلا: [من الوافر مجزوءا] (')

فَفُــلن مَــا شِـــنْتَ فـــي شِــمْرِي ثم نراه يقول من قصيدة أخرى: [من البسيط](ז)

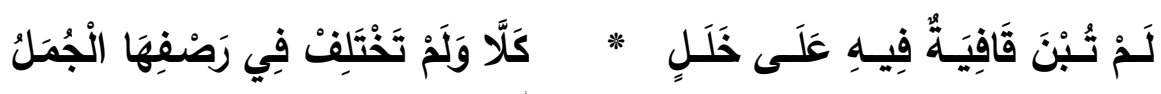

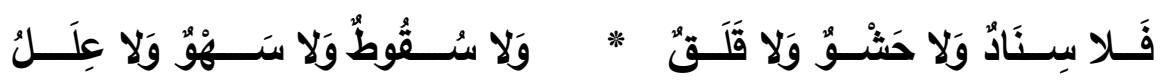
فالبيتان يظهران مدى حرصه على أن تكون قصيدته ذات جودة عالية خالية من عيوب القافية، ولم تكن كذلك نابية قلقة، فهي تخلو من الحشو والسقوط والسهو، وتلك كلها أمور ترتد إلى عملية المراجعة والتثقيف والتهذيب والتشذيب التي كان يمارسها البارودي على شعره قبل أن تتلقفه ألسنة الناس أو يلقوا إليه السمع. ولا يني يشير إلى ما يبذله من معاناة في نظم الشعر ، وما يلقاه من جهد فني

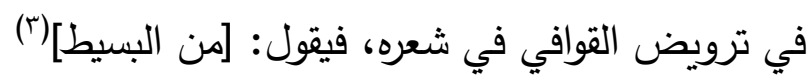

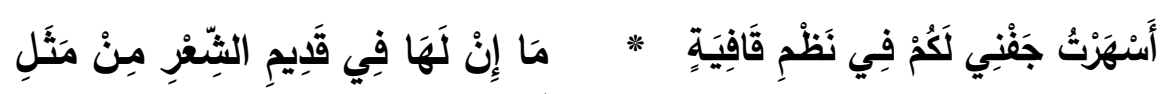

(1) (1) ديوان البارودي (1) دوان البارودي وما يليها.

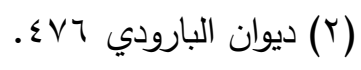
(Y) ذاته سا إ وما يليها. 


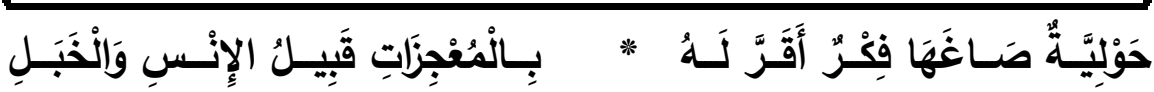

فهو يمدح قصيدته بأنها لا مثيل لها في شعر القدامى (الأوائل) وذلك لأنها جاءت نتيجة سهر وتفكير ، فكأن الثاعر قد احتثد لها احتثادا، ولفظ السهر هنا مما كان يعول عليه شعراء الصنعة قديما بلفظ "بتُّ" أو "أبيت"، فهذا ولها

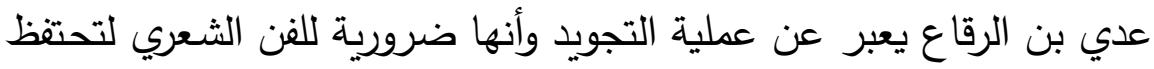

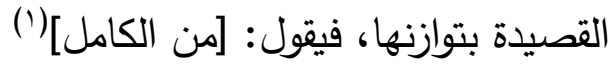

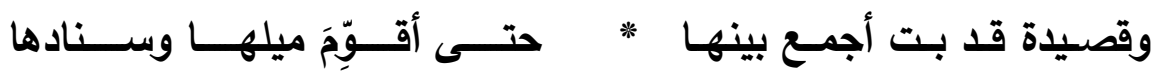

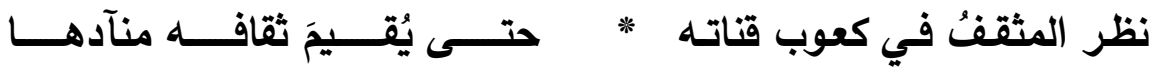

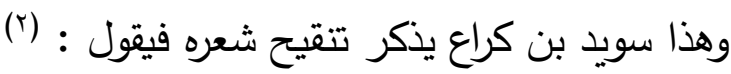

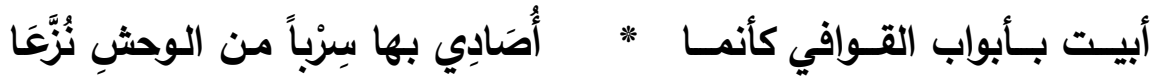

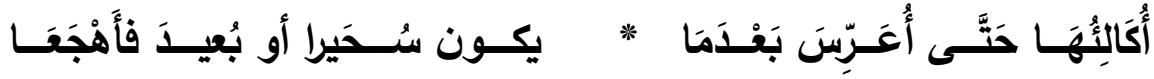

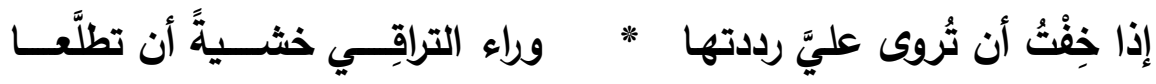
ويعلق ابن جني قائلا: "وإنما يبيت عليها لخلوه بها ومراجعته النظر فيها...

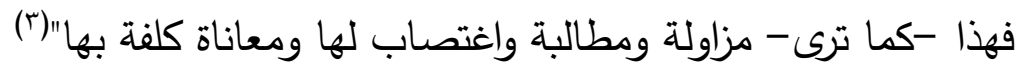
والبارودي في هذا البيت "أسهرت جفني إلخ...يؤكد احتفاءه بالقديم وتجاوزه في آن، فقد قال في موضع من شعره عن قصيدته: [من الكامل]"(؛)

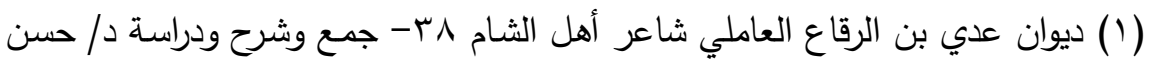

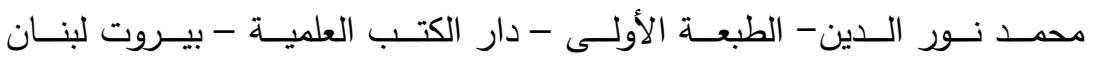

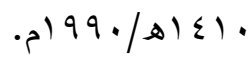

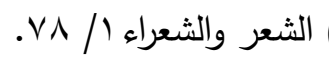

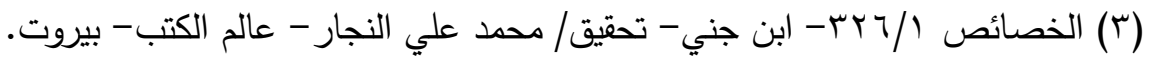

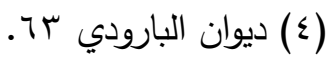


فاسـتجلها تلمـح خلالكك بينها * فــي وشــي بـرد للكـلام قشـيب كزجاجة التصوير شفت فاجتلت * مسن وصـفه مـا كـان غيـر قريـب ومن ثم "استطاع الصـراع بين (النفس/المصورة في الثعر ) وبين (الثـعر

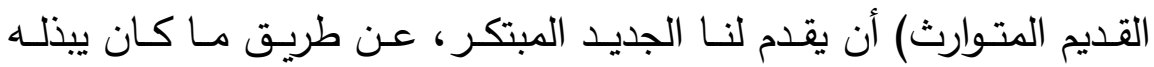
البارودي مـن سـهر وتعب في صـياغة القصـائد التي يحـاول فيها منهجـا

متميزا"(1)

ثم يصف البارودي قصيدته بأنها حولية- نسبة إلى الحول أي السنة والعام يريد بذلك أنـه قضى وقتا طويلا في مراجعتها وتتقيحها وتهذيبها وتشذيبها ليضمن لها الخلود والبقاء والذيوع في بؤرة التداول القرائي والمسموع في آن معا وليقدم لجمهوره زبدة فكره الذي يدين لـه الإنس والجن، شـأنه في ذلك شأن شعراء الحوليات في العصر الجاهلي، والحوليات- كما هو معروفظـاهرة شعرية أطلقت على بعض شعراء الجاهليـة، وفي مقدمتهم الثـاعر زهير بن أبي سلمى "لأنه كان يحوك القصيدة في سنة والحكاية في ذلك عن لن

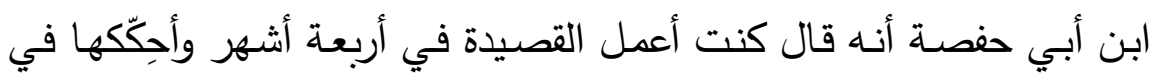

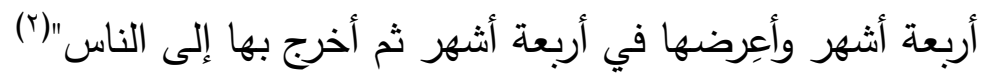
وإذا تـدبرنا قولـه: "صـاغها فكر أقر لـه بـالمعجزات قبيـل الإنس والخبـل" استطعنا أن نحكم بهيمنـة العقل الواعي في عمليـة الصنعة الثـعرية لدى

(1) الثـعر العربي الحديث في القرن التاسـع عشر - نظـرة تاريخيـة نقديـة 9؟ ؟- د/

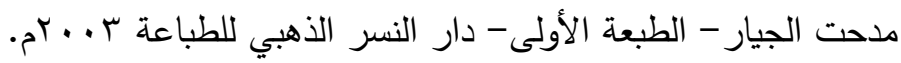

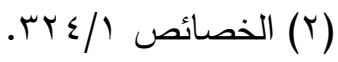


البارودي، وهو ما كرره أكثر من مرة في شعره، فالقصيدة لديه صفحة الفكر ، كما في قوله: [من الطويل](')

إذا اعتورتها ذُكرةُ النَّفسِ أبصَرَت لها صُورةً تختالُ فى صفحةِ الفكرِ

$$
\text { ولؤلؤة الفكر ، كما في قوله: [من الطويل](؟) }
$$

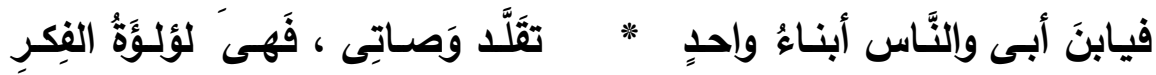

$$
\text { وهدية فكر كما في قوله: [من البسيط](") }
$$

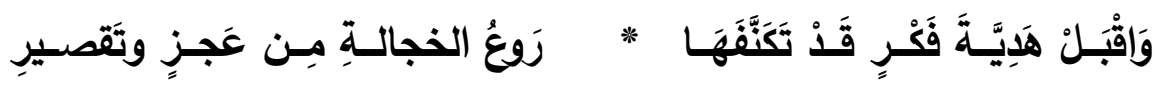

$$
\text { ويقول: [من الطويل](๕) }
$$

يقصرُ قابُ الفكرِ عنها، وَ ينتهى أخو الجدَّ عنْ إدراكها وَ هوَ ذاهلُ

ثم كيف نفسر قوله: [من البسيط][)

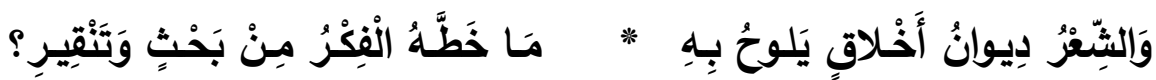

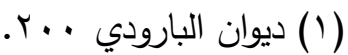

$$
\begin{aligned}
& \text { (r) ذاته r. } \\
& \text { (ب) ذاته } 0 \text { (ب) } \\
& \text { ( ) ذاته } \\
& \text { (0) ديوان البارودي }
\end{aligned}
$$


أليس "البحث" و"التنقير" نابعين عن هذا الفكر الذي يعني المعاودة الذهنية وكدها وتقليبها حتى تأتي بشيء مصقول يشهد للشاعر بالفوقية والتبريز في

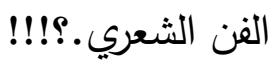

في هذا السياق تنبئ دلالة الصنعة عن مدلول العقلانية الملازم لها. وإذا كان "كمال العقل" هو جماع الأدوات التي تتميز بها الأضداد في الصنعةفيما قال ابن طباطبا قديما- فإن تحقق كمال العقل في قصيدة البارودي يعني أن هذه القصيدة لا ترخي العنان للخيال الشعري أو تتركه مرسلا طليقا متحررا، بل تعقله إلى ما يشده من قواعد الإصابة وأصول اللياقة العقلية، ومن ثم ...فهي "آثار العقول" التي تذكرنا بالتيار الأوسع من التقاليد التي تنتمي إليها في عالم الثعر الذي هو "صوب العقول" وليس "فيض العواطف"

ولا يخفى أن البارودي في جعله الثعر فيض العقل والفكر مسبوق بأبي تمام الذي اعتنق هذا المذهب وصار رائدا له غير مسبوق فيه - حسب تصفحي

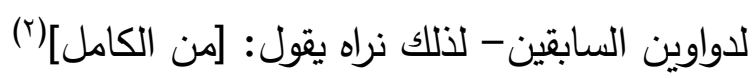

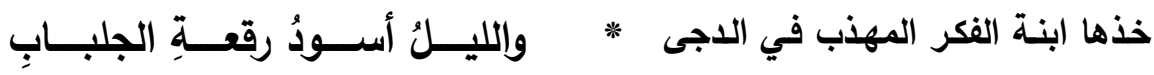
ويقول: [من الوافر](r)

(1) استعادة الماضـي "دراسـات في شعر النهضـة" بـ ا - د/ جابر عصفور - الطبعـة

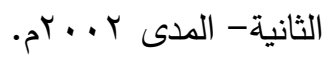
(ץ) ديوان أبي تمام بشرح الخطيب التبريزي / / • 9- تحقيق محمد عبده عزام- الطبعة الخامسة- دار المعارف $9 \Lambda$ ام..

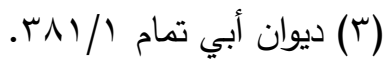




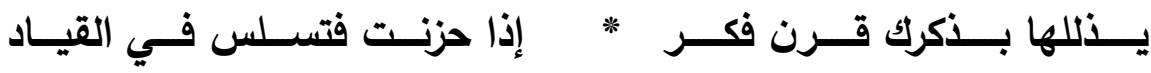

ويقول: [من الطويل](')

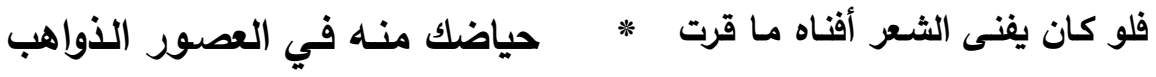
ولكنه صوب العقول إذا انجلت * سـحائب منــه أعقبــت بسـحائب ومن ثم ربط البارودي بين الشعر والفكر وجعل بينهما علاقة تآزر لا علاقة

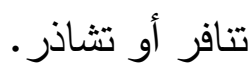
كذلك يعد سماع الثاعر لشعره مما هو على رابطة وواشجة بالصنعة الفنية، فقد كان البارودي في شعره يزجي بعض الوصـايا أو النصـائح للشعراء، ومن

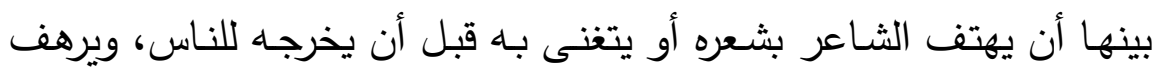
مسامعهم إليه ليفحصه وببعد عنه ما لعله كربه من عيوب في الموسيقى وزنا وقافية، فيقول:[من السريع] (r)

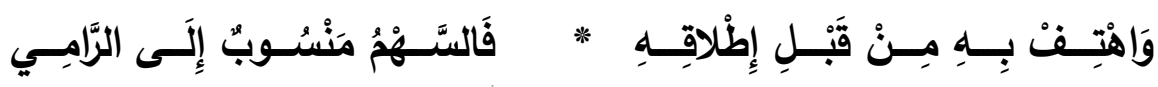
ولعل هذا يذكرني بصنيع أهل يثرب مع النابغة الذبياني حينما أقوى في قوله:

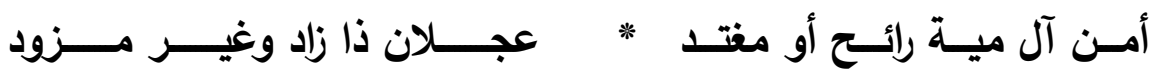

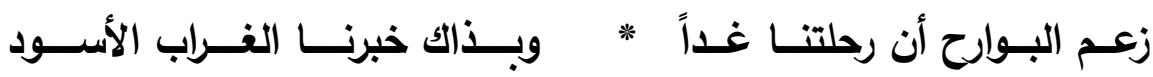

$$
\begin{aligned}
& \text { (1) ذاته / (Y) } \\
& \text { (Y) ديوان البارودي . . . آ. }
\end{aligned}
$$




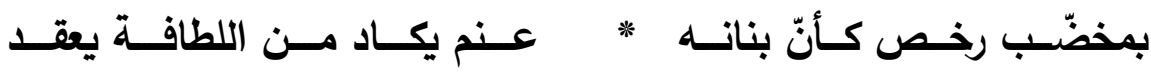
فلما قدم المدينة عابوا عليه ذلك، ولكنه لم يأبه لقولهم؛ حتى أسمعوه إياه في غناء؛ وأهل القرى ألطف نظراً من أهل البدو، فقالوا للجاريـة: إذا صرت إلى إلى القافية فرتلي، فلما قالت: "الغراب الأسود" بالضم مع أن القافية مكسورة، علم

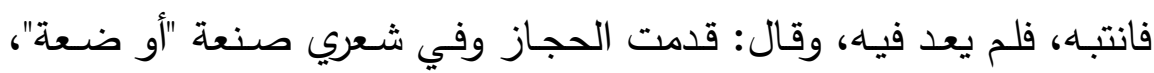
ورحلت عنها وأنا أشعر الناس (') وتأسيسا على ذلك فإن البارودي ينادي هنا بأن يهتف الشاعر بشعره ليسمع نفسـه، لمـا يحققه هذا السماع من أثر في إيضـاح المعنى وتحديد الفروقات الدقيقة في إنتاج المعنى، ولما لله من مؤثرات عديدة في خدمـة النص تنقيحا وتهذيبا. ولا أدلَّ على هذا التتقيح من اختلاف القصـائد كما نشرت في الديوان عن نصها المنشور أول الأمر في الوسيلة الأدبية للمرصفي. يقول عارف حجاوي: "خدم البارودي شعره بأن جمعه قبل وفاته، وكتب له مقدمة، وقد غير في أبياته بعض التغيير ، وخفف من غلواء الغزل والمجون بعض التخفيف، ويبدو هذا واضحا من خلال مقارنة أبيات الديوان بأبيات نشرها المرصفي في "الوسيلة الأدبية"... وقد طبع ديوانه بعد وفاته"(؟) 
ويقـول محققـا الـديوان: "ويلاحظظ أن الجزء الثاني مـن الوسـيلة طبع سـنة

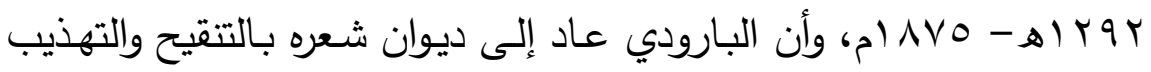

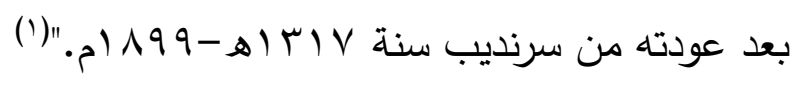

وقد جعل د/ جابر عصفور مدة المنفى التي قضاها البارودي (سبعة عشر عاما وبعض عام) سببا في معاودة النظر في هذا شعره الذي لم يعد لله من مجد الدنيا سواه، مشبها إياه بأبي العلاء المعري الذي ظل رهين عزلة سجونه الثلاثة التي تحدث عنها في شعره، فكما أتاحت هذه السجون التوحد لأبي العلاء تنقيح شعره فأخرج لزومياته، فإن توحد البارودي أتاح له إعادة النظر في شعره وتتقيحه، بل دفعه ذلك أن ينهج نهج المعري في لزومياته(؟) ومن الأمثلة على ذلك قوله في الوسيلة الأدبية:(ॅ)

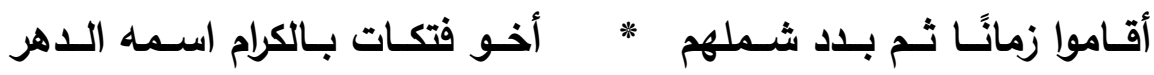
فقد صار في الديوان:(๕) أقـاموا زمانَـا ثـم بـدـد شـملهم * ملـول مـن الأيـام شـيمته الغـدر ومطلع قصيدته التي يعارض فيها رائية أبي نواس، فقد كانت في الوسيلة

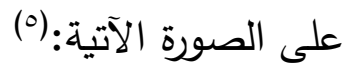

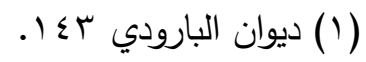

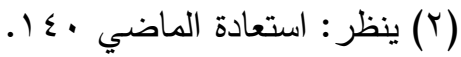

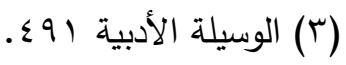

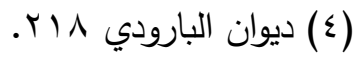

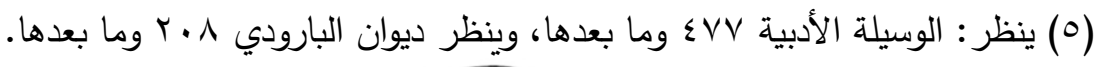




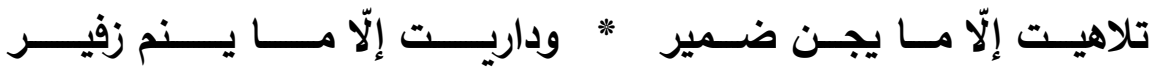

وهل يستطيع المرو كتمـان أمره * وفـي الصـــر منــه بـارح وسـعير

$$
\text { (') ثم صار في الديوان }
$$

أبى الثوق إلّا ما يحن ضمير * وكــل مشـــوق بــالحنين جـــير

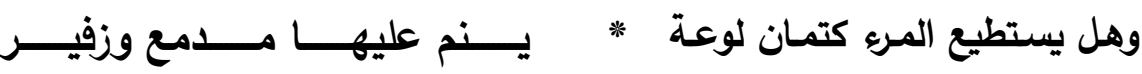

$$
\text { (ץ): وهنالك قصيدة ميمية في الوسيلة }
$$

ذهـب الصـبا وتولــت الأيسام * فعلى الصـبا وعلىى الزمــان سـلام صارت بعد المعاودة والتنقيح في الديوان إلى هذه الصورة:(ץ)

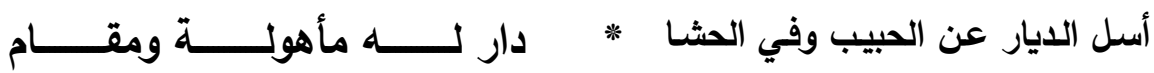

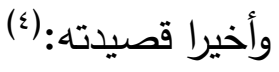

تصابيت بعد الحلم واعتادني شجوي * وأصبحت قد بدلت نسكي باللهو

$$
\begin{aligned}
& \text { (1) ديوان البارودي ؟ • ب وما بعدها. }
\end{aligned}
$$

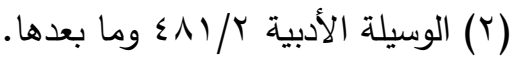

$$
\begin{aligned}
& \text { (ז) ذاته آسه وما بعدها } \\
& \text { (乏) ذاته VIV وما بعدها }
\end{aligned}
$$


التي لها صورة ثانية مغايرة في الديوان هي:(') تصابيت بعد الحلم واعتادني زهوي * وأبــلت مــأثور النزاهـة بـاللهو ومن ثم فالشـعر موهبـة فطريسة ولود، ومن لا موهبـة لـه فـلا شعر لله، فـإذا أضيفت إلى هذه الموهبة الفطريـة ثقافة وإتقان فلا مناص حينئذ من تقديم مخرج يتمثل في شاعر مفلق فذ. 


\section{المبحثَ الناني : خلود الشعر لصامبه بـهد موته.}

لا شك أن البارودي فطن إلى تلك الرؤيـة أعنى خلود الثعر لصـاحبه بعد

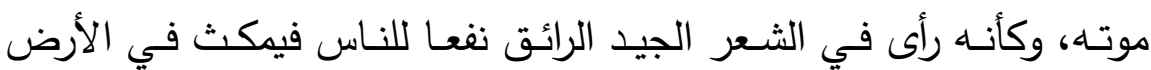
ليخلد قائله الذي أضحى رهين جدثه، وأن ما دونه من شعر ساقط غير جيد فسيذهب جفاء أو أدراج الرياح ولا بقاء لذكر صـاحبه، لأن الشاعر المجيد ليس عمره كبقية الأعمار ، لأنه دوَّن بشعره كل فخار ، فيبقى بأسماع الزمان دويـه، "وإذا كان البشـر الاعتياديون يجدون في الولد عوضـهم الكافي عن زوالهم من الدنيا، فالفنان - الثاعر - لا يجده إلا في خلقه الفني"(')

\section{يقول البارودي: [من الطويل](؟)}

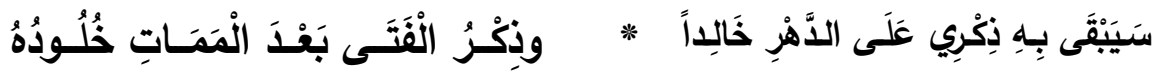

فالثعر سبب في خلود قائله بعد رحيله ولن يكون كذلك إلا إذا كان مناط إجادة وتحبير ، وقد صـارت هذه الرؤيسة متنفسا للبوح لكثير مما كان يمور في نفسه ويعتلج في صدره، فنراه يصف شعره بأنه سيكون اللسان الناطق لمن يخلفه بعد رقدته في الثرى، وكأنه حي يلتقيه، فيقول [من الطويل]:(†)

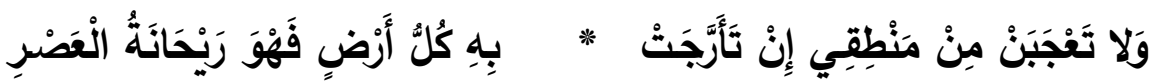

(1) هـاجس الخلود في الثـعر العربي حتى نهايـة العصر الأموي • با-- عبد الرازق

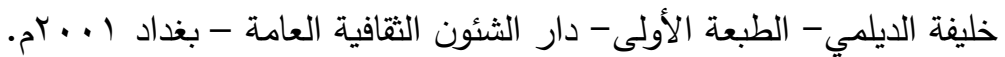

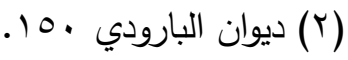

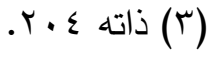




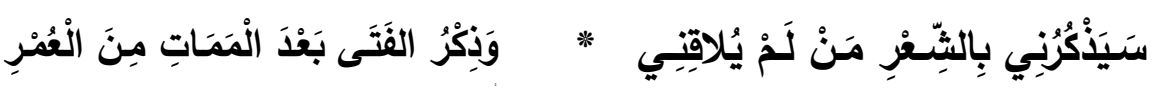

ولا يني يجنح بالفكرة إلى مقام الزهد، فيقول[من الخفيف]: (')

فاحتقب سيرة المحامـ، فالأكـ * ــر حيـاة لمــن طوتــه المنــونُ

والمعنى نفسه يردده مع اختلاف في سبب الخلود في رثائه علي بن رفاعة الطهطاوي، فيقول[من الطويل]:(ץ)

فإن يك أودى فهو حي بفضله * ومسن كـان مـذكورا فلـيس بفـاني أما خلود الثعر نفسه على الرغم من موت صاحبه فلم يغب عن وعي البارودي، وأغلب الظن في ذلك أنه كان يرى خلود الثعر لصاحبه أو خلود

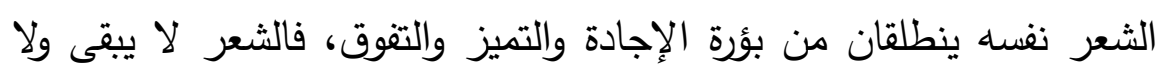
يخلد إلا إذا صاغه صاحبه صياغة عبقرية محكمة، فإن لم تسلم للشاعر مثل هذه الصياغة، لم تسلم له مقاليد الثعر ، بل لم تسلم له شروط الانتساب

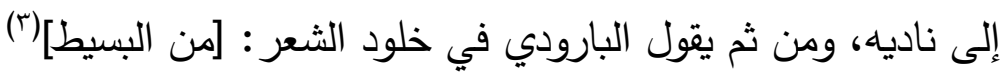

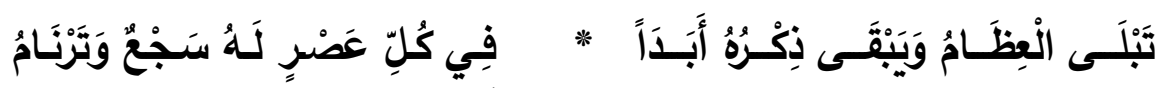
ويقول: [من الخفيف]؛)

(1) ديوان البارودي 790.

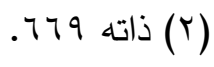

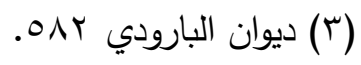

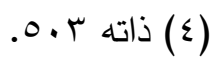




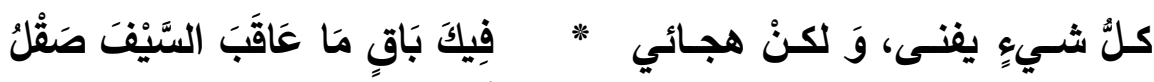

ويقول: [من البسيط ][)

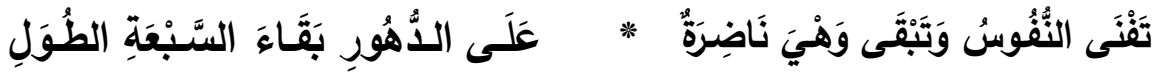

ويرى د/ جابر عصفور في هذا البيت أن "الدال المراوغ في نهايته ينطوي على مدلول مزدوج، يجمع في إشارته ما بين المعلقات السبع والسور السبع الطوال من القرآن الكريم، فهو دال يتجاوب مع غيره من الدوال ليصل حكمة فئ الثـعر بالكثـف ويصـل حكمـة الثـاعر بحكمـة الأنبياء ويـرد نبـوة الثـاعر ومعجزة القصيدة إلى تصور إسلامي متأصل لا سبيل إلى تجاهله"(؟) . ويقول أيضـا: "لنقل - مـع البارودي- - إن خلود الثـعر قرين قدرة الثـاعر على أن يضم شتات الكون في بعض أحرف"(؟) ولكن هذه القدرة قرينة حكمة إنة يقر لها بالمعجزات الإنس والجان (£) وذلك لأنها قادرة على أن تبث الحياة في الأشياء والكائنات، أو تشيع الدمار في أعتى الأشياء، فهي من ناحية -

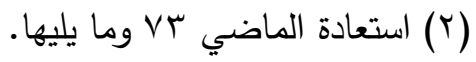

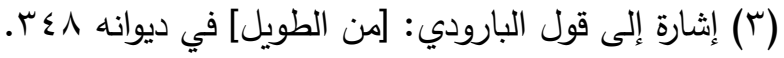

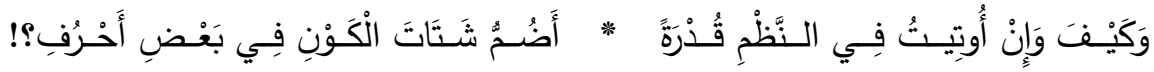
(ع) إثارة إلى قول البارودي: [من البسيط تاما] في ديوانه ؟ إع.

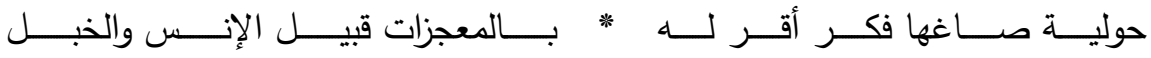


"تفيء على الدنيا" بكل ما يعمرها ويكملها(') ولو تليت - من ناحية أخرىعلى جبل "لانهار في الدو ريده" (r)

وبقاء الشـعر على الرغم من موت صـاحبه فكرة قديمـة لهج بها كثير من الشعراء وتغنوا بها في معرض الحديث عن الزهو بالفن الشعري، فها هي ذي الخنساء تقول: [من المتقارب](ॅ)

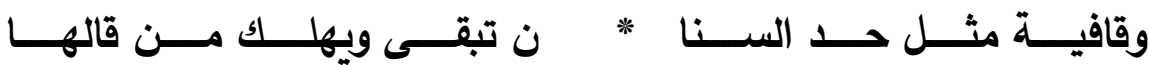

ويقول دعبل الخزاعي: [من الطويل]؛)

يموت رديء الثعر من قبل أهله وجيده يبقى وإن مات قائله

ويقول أبو نواس: [من الطويل](0)

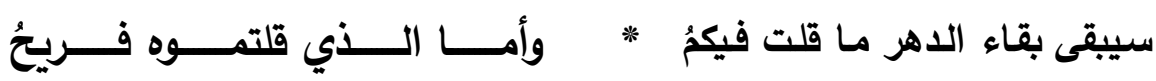

(1) إثارة إلى قول البارودي في أديب هندي: [من الطويل] في ديوانه جـــ.

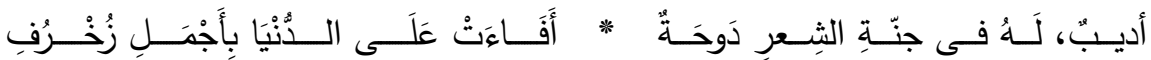
(Y) إثنارة إلى قول البارودي: [من الطويل] في ديوانه 9 ؛ ا.

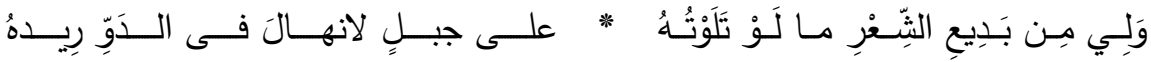
(ץ) ديوان الخنساء بشرح ثعلب 7 ـ 1- تحقيق د/ أنور أبو سويلم- الطبعة الأولى - دار

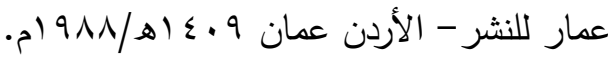

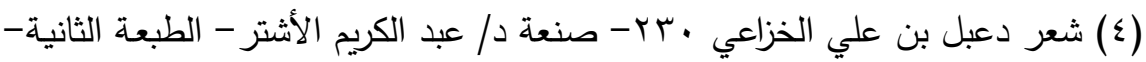

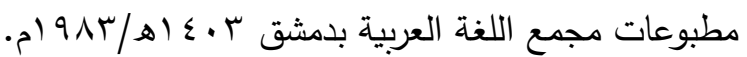

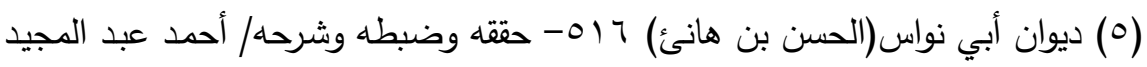
الغزالي-نشر دار الكتاب العربي- بيروت لبنان. 
ويقول البحتري: [من الطويل](')

إليـك سـرت غـر القـوافي كأنهـا * عواكب ليـل غـاب عنها أفولها

بــائع تــأبى أن تــدين لثــاعر * سـواي إذا مـا رام يومـا يقولهـا

تـزول الليـالي والسـنون ولا يـرى * على العهد طول الدهر شيء يزيلها

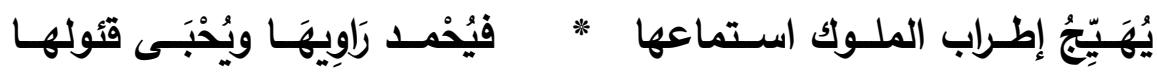

ويقول أيضا: [من الطويل]r)

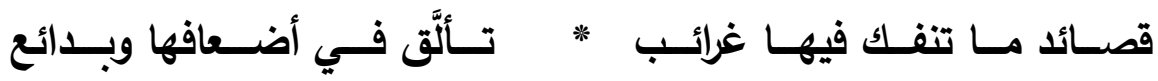

مكرمسـة الأنســاب فيهـا وســائل * إلى غير من يُحْبَى بها وذرائـع

تنـال منـال الليـل في كـل وجهـة وتبقى كما تبقى النجوم الطوالـع

ولا أدل على ذلك مما "قاله عمر بن الخطاب رضي الله عنه لابنة زهير حين سألها: ما فعلت حُلل هرَِمِ بن سنان التي كساها أباك؟ قالت: أبلاها الدهر، قال: لكن ما كساه أبوك هرماً لم يبله الدهر، وقال عمر رضي الله

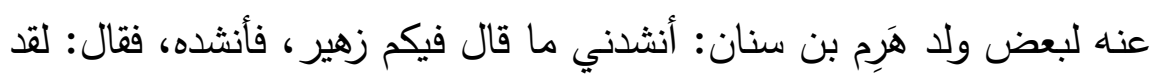

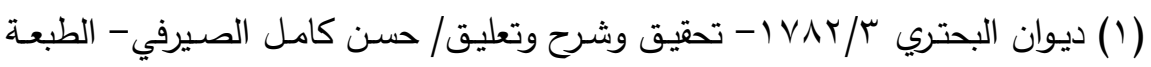
الثالثة- دار المعارف بمصر ـ 97 ام.

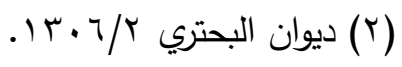


كان يقول فيكم فيحس، قال: يا أمير المؤمنين إنا كنا نعطيه فنجزل، قال

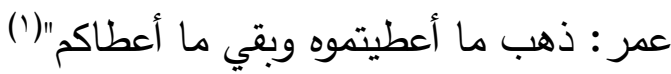

يقول محمد عبد المطلب: "إن استهداف الثعرية للخلود كان مصاحبا لقدرتها التأثيرية المتجددة القادرة على مغالبة الحصار الزمني والمكاني، وقدرتها على استصحاب طرفيها: المنتج والمتلقي، لكن الشعرية كانت واعية بالحضور المؤقت للطرف الثاني وبالتالي لا بد من إكساب الثعرية قدرة إنتاجية متجددة، معنى هذا أن خصيصة الثعرية الأولى هي التراكم، لأنها لا تعرف إلى وله

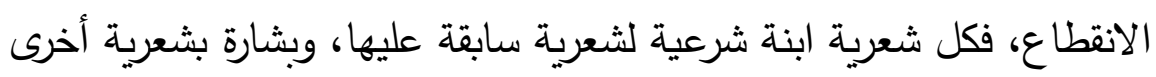

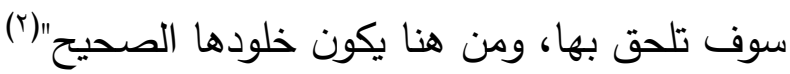
وخلود الثعر ناجم عن ذيوعه وسيرورته، تلك السيرورة التي زُهِيَ بها الثعراء كثيرا في أشعارهم، وأدرك حيثياتها نقدنا العربي القديم، فقد أفرد لها ابن رشيق بابا في عمدته أسماه "باب سيرورة الشعر والحظوة في المدح"(؟) وقال فيه: "كان الأعشى أسيرَ الناس شعراً، وأعظمَهم فيه حظاً، حتى كاد ينسى الناس أصحابه المذكورين معه؛ ومثله زهير ، والنابغة، وامرؤ القيس؛

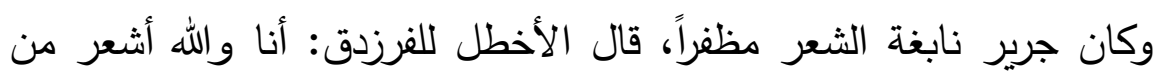
جرير، غير أنه رزق من سيرورة الشعر ما لم أرزقه، وقد قلت بيتاً لا أحسب أن أحداً قال أهجى منه، وهو:

قوم إذا استنبح الأضسياف كلبهم * ق قالوا لأمهـم: بـولي على النـار

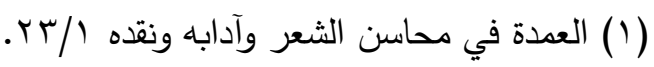

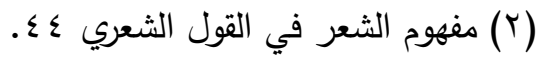

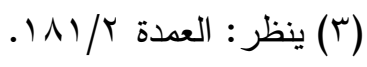




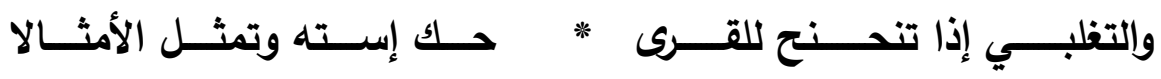
فلم يبق سقاء ولا أمة حتى روته. قال الأصمعي: فحكما له بسيرورة (الثعر "( ) (1)

ومن ثم وصف البارودي شعره بأن له أوابد، فقال: [من البسيط][؟(

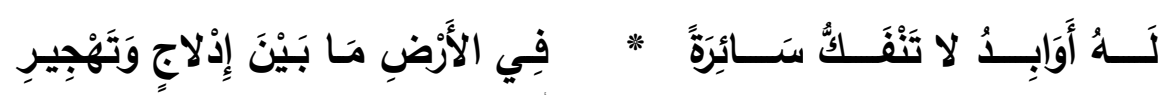

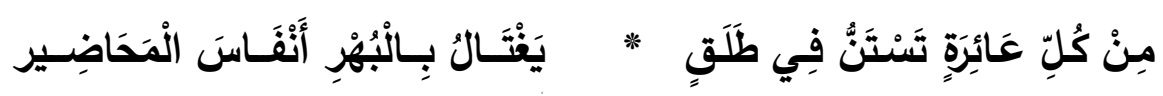

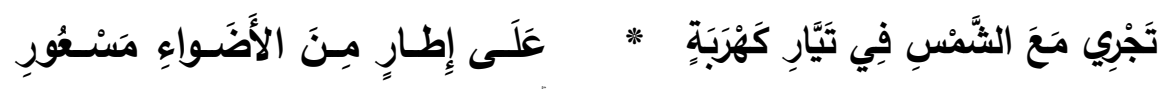

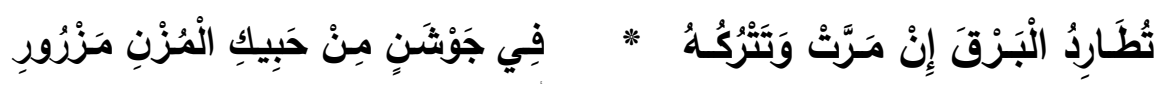
فسيرورة الثعر وذيوعه تتناغم مع مفهوم الأبيات الأوابد، وهي "الأبيات السائرة كالأمثال، وأكثر ما تستعمل الأوابد في الهجاء، يقال: رماها بآبدة،

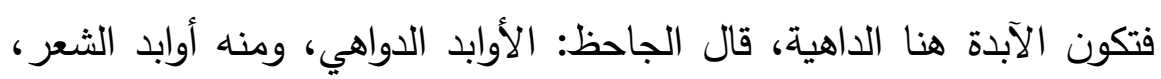
حكاه عن أبي زيد، وحكى: الأوابد الإبل التي تتوحش فلا يقدر عليها إلا بالعفر، والأوابد الطير التي تقيم صيفاً وشتاء، والأوابد الوحش؛ فإذا حملت أبيات الثعر على ما قال الجاحظ كانت المعاني السائرة كالإبل الثاردة المتوحشة، وإن شئت المقيمة على من قيلت فيه لا تفارقه كإقامة الطير التي

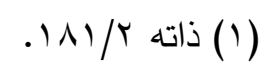

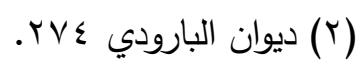


ليست بقواطع، وإن شئت قلت: إنها في بعدها من الشعراء وامتناعها عليهح

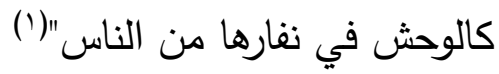

والبارودي في البيت الثاني يشبه القصيدة في سيرورتها بالفرس العائرة التي تتطلق مسرعة في مرح ونشاط، ثم يصفها في البيت الثالث بأنها تجري مع لئي الثمس في تيار كهربة دلالة على أنها أصبحت من الثهرة بمكان، وأنها واضحة لكل ذي عينين، ثم يأتي في البيت الأخير ليدلل أكثر على ذيوعها وسرعة انتشارها بأنها تطارد البرق، وليس ثمة قصيدة على هذه الثاكلة إلا إذا كانت حيوية فاعلة بما يكتنز فيها من طاقات إبداعية أتاحت له الذيوع والانتشار في بؤرة التداول القرائي والمسموع.

وفي قـول البـارودي: "تجـري مـع الثـمس فـي تيـار كهربـة.... وتطــارد البرق...إلخ ربط للشعر بالنور والضـوه وبيان مدى مـا لهما من أهمية في إبراز الخطأ من الصواب، أو أهمية في تصحيح المسار، وهذا الربط لم يغب

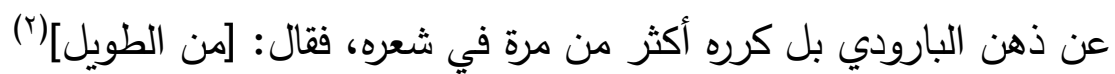

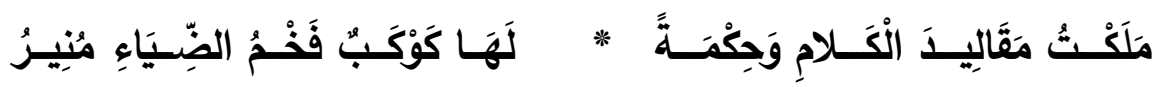
وقال أيضا: [من الطويل](؟)

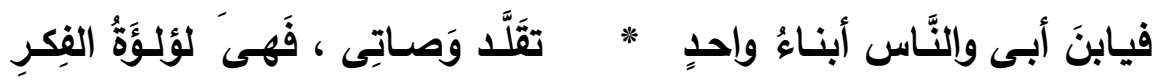
ومن ذلك قوله في شاعر هندي: [من الطويل](؛)

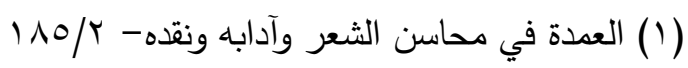

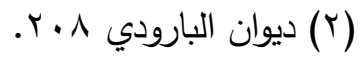

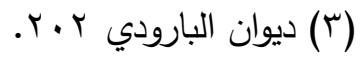

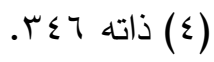




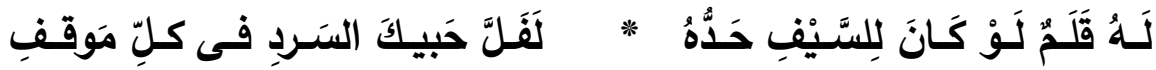

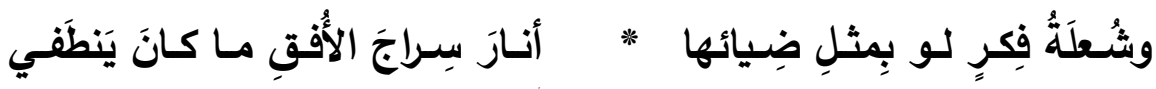
ومنها قوله واصفا شعره: [من البسيط](')

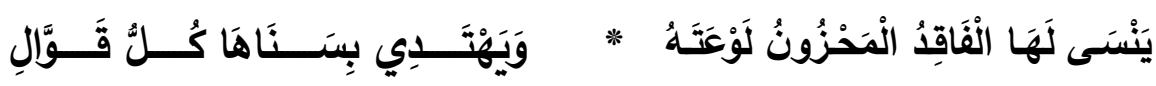
ومنه قوله مشيدا بعظمة الأهرام: [من الطويل](؟) ولا برحت في الدهر وهي خوالد * خــود الـدراري والأوابـد مسن شـعري ومنه قوله: [من الطويل] (r)

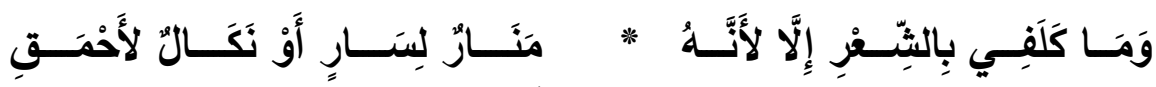
ولعل في ربط الثعر عند البارودي بالنور والضوء مردودا إلى تعريف الثعر لديه في مقدمته التي سطرها لديوانه، فقال: "فإن الثعر لمعة خيالية يتألق وميضها في سماوة الفكر، فتتبعث أشعتها إلى صحيفة القلب، فيفيض بلألائها نورا يتصل خيطه بأسلة اللسان، فينفث بألوان من الحكمة، ينبلج بها

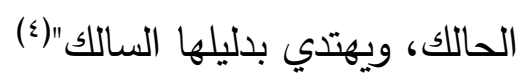

$$
\begin{aligned}
& \text { (1) ذاته سم؛ وما يليها. } \\
& \text { (r) ذاته }
\end{aligned}
$$

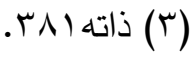

(§) ديوان البارودي - من المقدمة سب وما يليها. 
وقول البارودي: "تجري مع الشمس في تيار كهربة" يشبه إلى حد قريب وصف أبي تمام لقصائده حينما قال: [من الطويل] (')

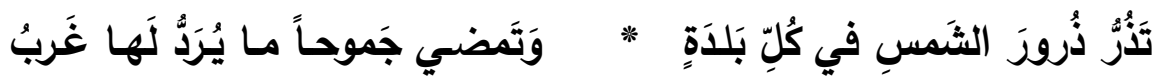
وقوله أيضا: [من الطويل](r)

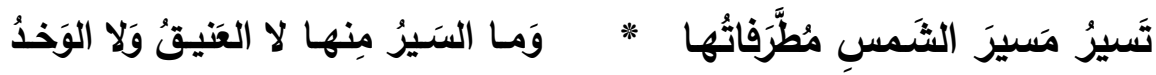
وها هو ذا يعود متحدثا عن سيرورة شعره فيلجأ إلى تشخيص الدهر في

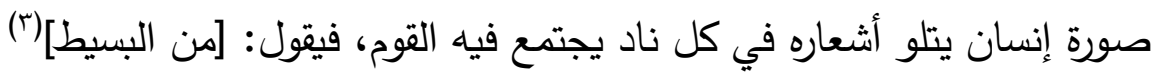

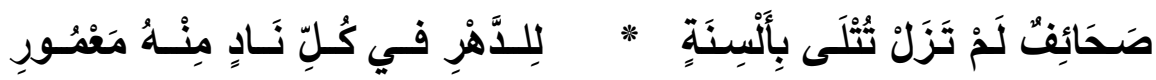
وغيـر خـاف هنـا أن الثـاعر مسـبوق بقـول أبـي الطيـب المتنبـي: [مـن (الطويل]

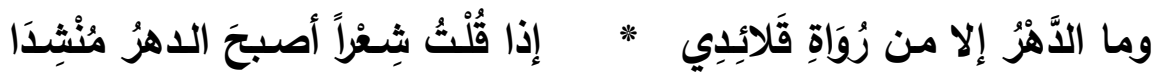

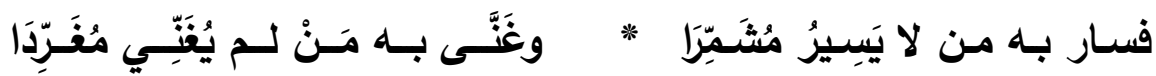
كما أن قول المتببي أعم من قوله، إذ لم يقصره على ناد معمور، كما أن المتببي شخص الدهر إنسانا كأنه يرتقب ما تجود به قريحته من شعر ليحمله

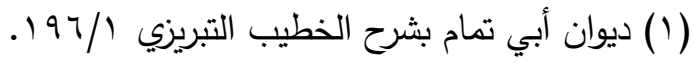

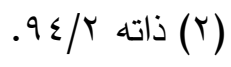

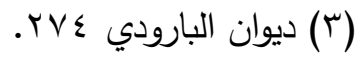

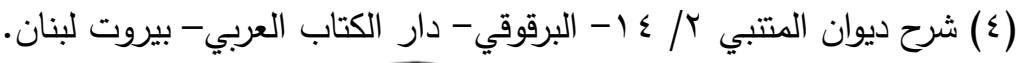


في الآفاق، على عكس قول البارودي الذي جعل الدهر إنسانا يقرأ ما هو مكتوب من صحائف شعره.

وأحيانا يعول على الاستعارة في هذا الصدد، فيذكر سيرورة شعره في حالتي

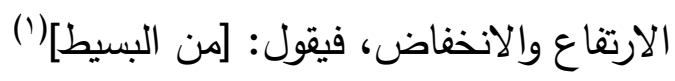

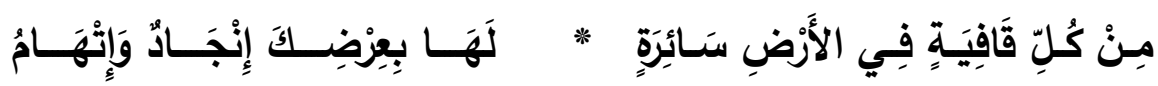
ثم يلجأ إلى الاستعارة والتشبيه، فيشبه سيرورة شعره بسيرورة السحاب من المشرق للمغرب، فيقول: [من الطويل](ب)

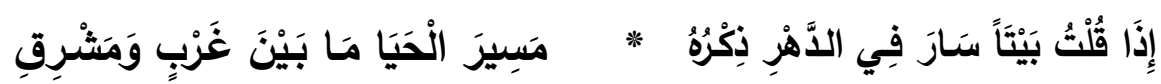
ويعدد إلى استخدام الاستعارة والكناية في آن معا في الحديث عن سبق شعره

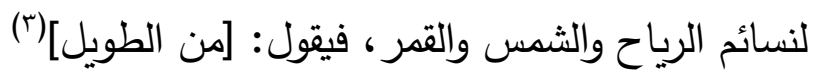

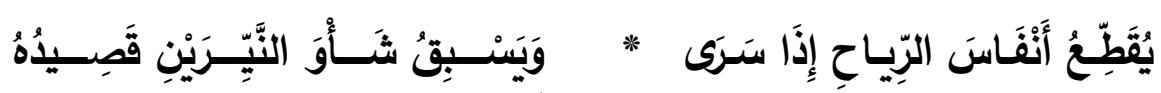
ولا يخفى أنه في قوله هذا مسبوق بقول المسيب بن علس: (๕)

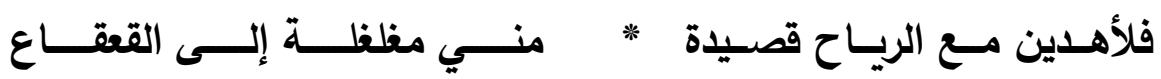

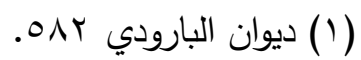

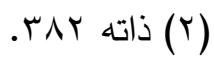

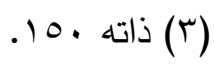

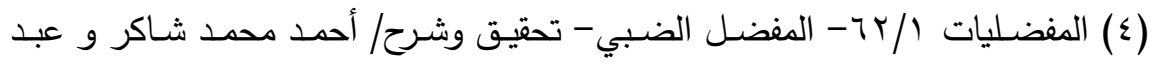
السلام محمد هارون - الطبعة السادسة- دار المعارف بالقاهرة. 


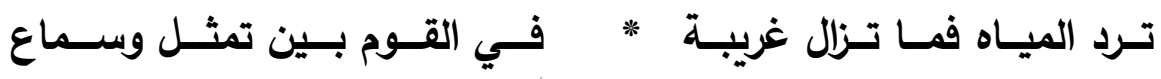

كما يشبه سريان شعره بأغنية مموسقة ينشدها حادي الإبل؛ لكسر الجمود

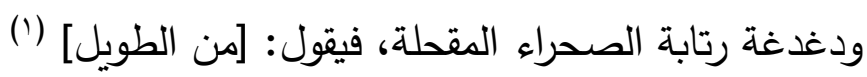

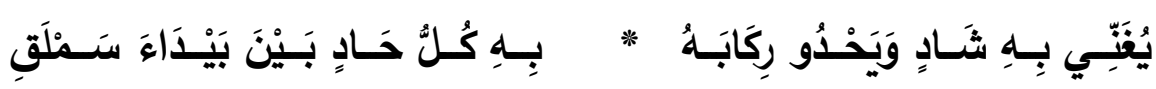

ولا يقتصر هذا على الحداة والإبل في الصحراء، بل إنه نشيد منغوم يردده

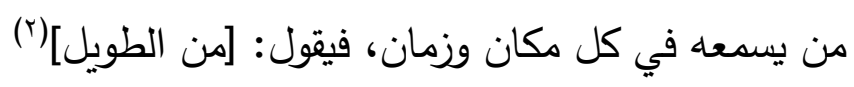

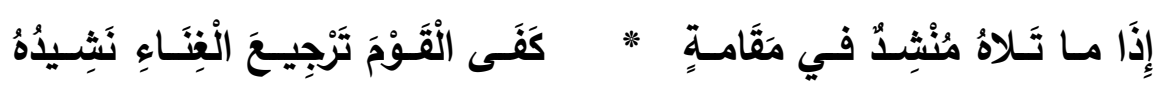
ولبيان مدى ما يقوم به الإنثاد من دور مهم في ذيوع الثعر وانتشاره وعلوقه

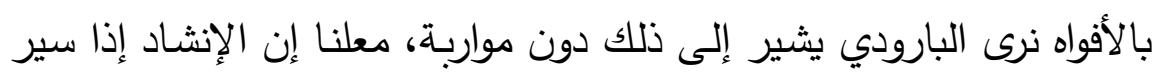

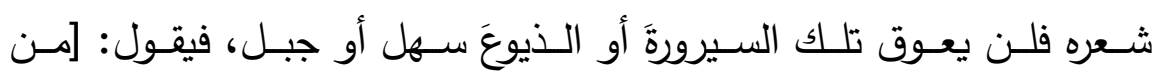

(") البسيط]

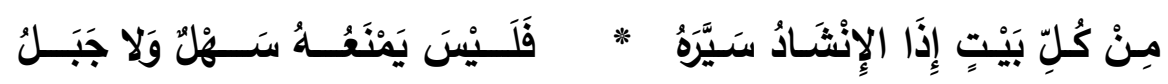

كما أن للإنثاد أثرا مهما وبالغا في إضفاء جماليات على النص تتمثل في

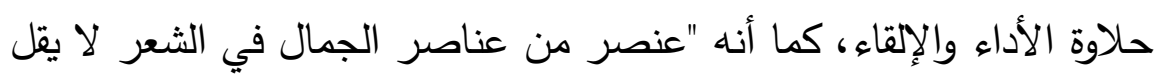

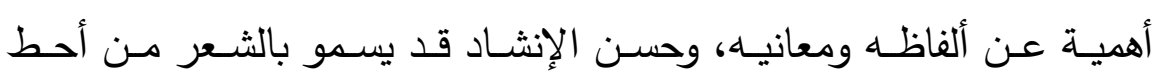

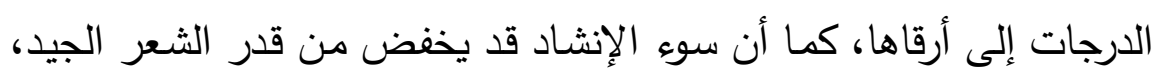

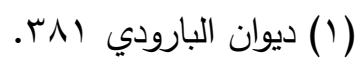

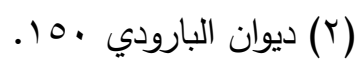

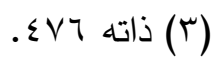




\section{العدد الحادي و الثلاثون}

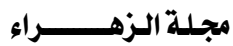

ويلقي على ألفاظـه العذبـة ومعانيه السـامية ظلالا تخفي ما فيه من جمال

وحسن" (1) (1)

ومن هنا يشير البارودي إلى دور الإنشاد في إضفاء الحسن والجمال على

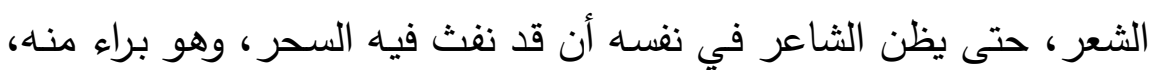

$$
\text { فيقول: [من الطويل]' }
$$

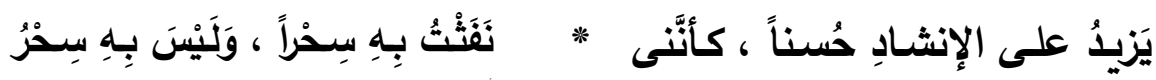
وعلى الرغم من سلاسة شعره وفصاحته فإنه يحمل في طياته العذوبة والجرس الذي يطرب السامع أو المتلقي لموسيقاه الناجمة أيضا من أثر إنشاده الذي يشبه نغم الحداء، مما يعني أن قصائده أو شعره عموما كما "زمن الورد"، فيقول: [من الطويل]"؟

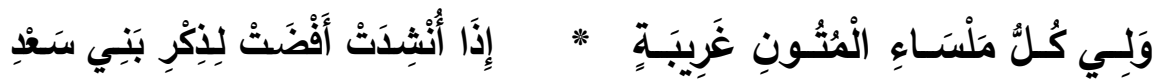

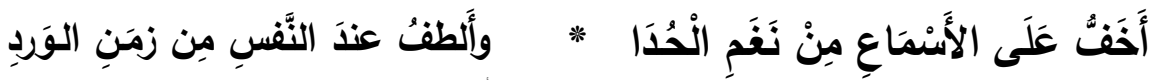
ولا شك أن البارودي يضفي على شعره طابع الغنائية والترنيم؛ إذ "بين الغناء والثعر صلة ونسب. وقد جعل بعض العلماء الثعر وليدًا من أولاد الغناء، لأن الثعوب القديمة كالبابليين، والمصريين، واليونانيين والعبرانيين، كانت تقرن شعرها بالموسيقى، وعرف هذا الشعر بالإنشاد، وقد كان الإنشاد في

(1) موسيقى الثعر ب 7 ( - د/ إبراهيم أنيس- الطبعة الثانية- مكتبة الأنجلو المصرية

$$
\text { . } 1904
$$

(Y) ديوان البارودي جr 9.

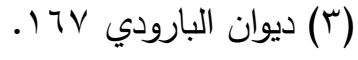


المعابد نوعًا من التراتيل الموجهة الآلهة، كما كان يستخدم في الحروب. ولهذا رأى العلماء أن الموسيقى، أولدت الإنشاد، والإنشاد هو والد الثعر " (') وسواء أكان الإنشاد وليدا للموسيقى أو العكس، فإن الشعر العربي نشأ في أجواء نغمية، وليست الأوزان والقوافي إلا أثرا من آثار منابعه الموسيقية. يقول د/شوقي ضيف: "وقد بقيت فيه مظاهر الغناء والموسيقى واضحة، لعـل القافيـة أهـم تلـك المظــاهر ؛ فإنها واضــحة الصـلة بضــربات المغنـين وإيقاعات الراقصين. إنها بقية العزف القديم وإنها لتعيد للأذن تصفيق الأيدي وقرع الطبول ونقر الدفوف كما تعيد ذلك شاراتُ أخرى للغناء نجدها في

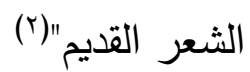

ثم نرى البارودي يتحدث عن قصيدته بأنها أنشودة الراكبين في أسفارهم، كما أن المجامع والأندية تتحلق حولها شوقا إليها، فيقول: [من الطويل](؟)"

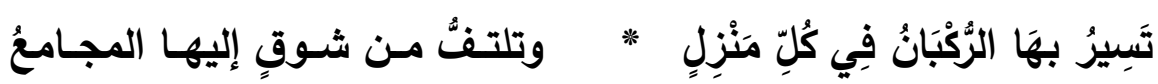
ولم يقتصـر دور ذيوع الثـعر لليـه على هذا فحسب، بـل كان للمخـالطين الأصـفياء دور كذلك في الاستماع لشعره والاستمتاع بـه، فهم ملاصـقون

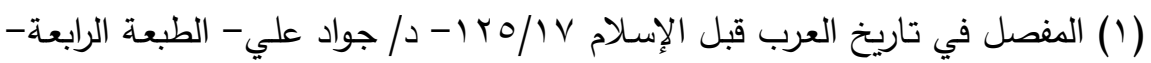

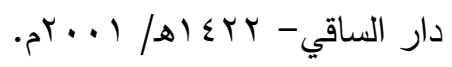

(Y) الفن ومذاهبه في الثعر العربي ^^؛ وما يليها - د/ شوقي ضيف- الطبعة الثانية

$$
\text { عشرة- دار المعارف بمصر . }
$$$$
\text { (r) ديوان البارودي } 9 \text { ابـ. }
$$ 
للشـاعر يسيرون معه حيث سـار لا يعصسون لـه أمرا، يقول البارودي: [من (البسيط] (1)

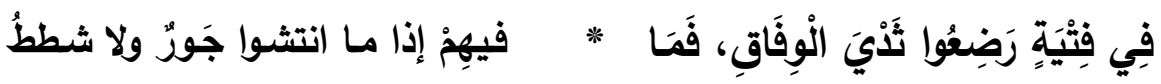

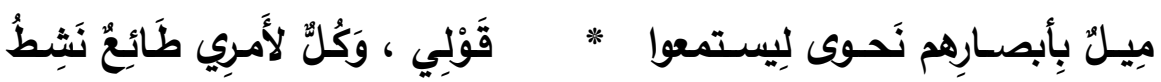

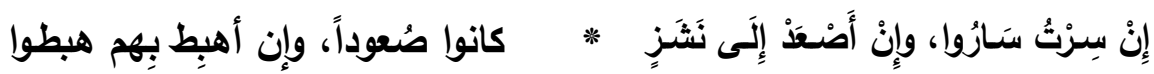
ولهذا نراه يتعجب غاية العجب وينده من قومه في إنكارهم ما شاع من أدبه وذاع من حكمه وأمثاله مع أنها دائرة بينهم تطرق مسامعهم في كل وقت

وحين، فيقول: [من البسيط]

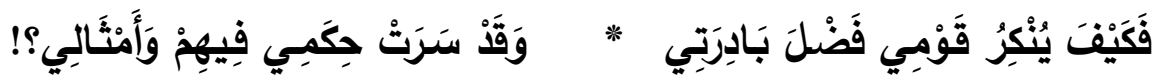




\section{المبـثث الثالث: التنفور على الآفرر:}

تتشكل هذه الرؤية من تقصي ظاهرة الأنا "الثاعر" في تداخلاتها

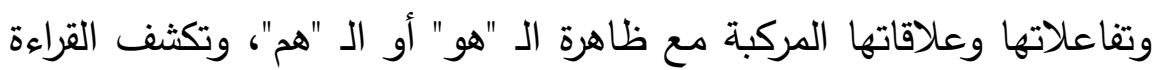
المتمعنة في شعر البارودي عن موقفين ثابتين غير متباينين يتمخضان في إبراز التفوق والاستطالة، يتجه الأول منهما إلى الثعراء القدامى، والآخر لمعاصري الثاعر أو من أتى بعده.

الموقف الأول: موقف موجه إلى سابقي البارودي من شعراء العصر

العباسي والأموي:

سبق أن أشرت إلى أن البارودي نفسه- في شعره- أقر باغترافه من معين الشعراء القدامى في العصر العباسي، والسير على منوالهم، من أمثال أبي نواس ومسلم بن الوليد والبحتري والمتنبي، وكأن ذواتهم الشعرية متذاوبة في كيانه ليخرج لنا ذاتا جديدة بروح حديثة تفوق ما دبجوه في فن القربض، وهذا إيمان منه في عدم ردم الهوة بينه وبين السابقين، وعدم استئصال

جذورهم التي طالما غذي عليها، فيقول: [من الطويل](')

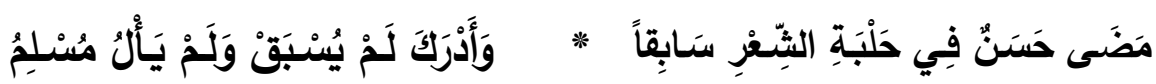

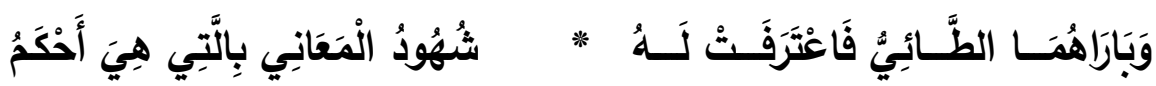

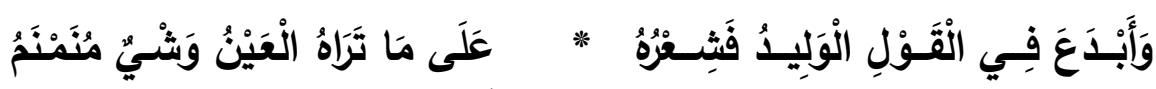

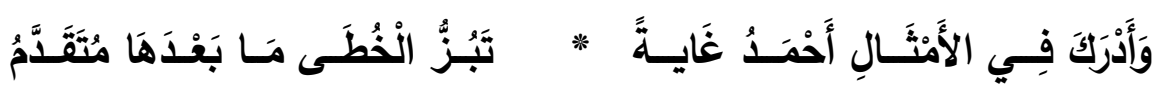
(1) ديوان البارودي 077. 


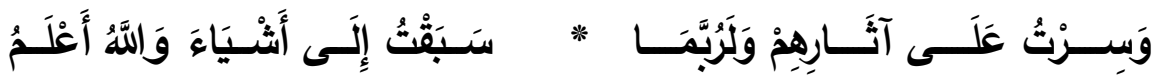

فنراه هنا يحدد الشعراء الذين ترسم خطاهم ونسج على منوالهم، حاصـرا إياهم في العصـر العباسـي الذي يمثل عصـر الازدهـار والانفتاح الحضـاري إلى جانب البداوة التي أعادوا صياغتها، كما أن هذا العصر أصبح- فيما بعدالأنموذج الأمثل لدى شعراء العصور اللاحقة في النسج على منواله واحتذاء طرائقق الثـعراء فيـه وهـو بذلك يحدد مذهبه الفني الذني يقوم على بعـث الأسلوب القديم وتعمد إحيائه، كما يفهم من قوله في وصف قصيدته: [من

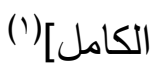

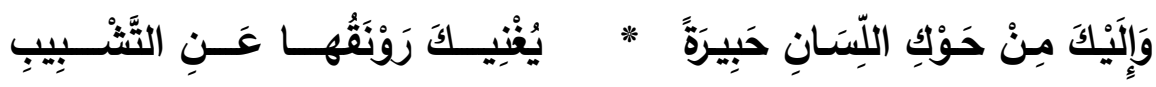

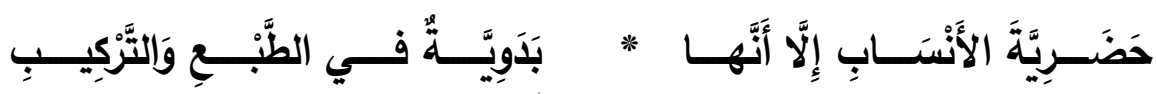
فالقصـيدة لديـه وإن كانـت ذات طـابع حضـري يربطها بالعصـر فهي في أصلها وتركيبها ذات طابع بدوي تراثي، ومن ثم فهي مزيجج من هذا وذاك، ئه ولا أدل على أنها حضرية في عصرها من قول البارودي في البيت الأول "حبيرة" يقصد بذلك الجدة.

كما أن البارودي لا يريد البداوة بطبيعتها القاسية الخشنة، بـل يريدها رمزا

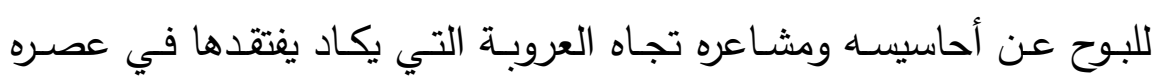
بشتى حيواته، إذ كان يطمح في أن ينتقل بشعر عصره عموما من الضعف الض والركة والإسفاف والجمود والصنعة المتكلفة التي رانت عليه حتى جعلته شعرا 
محنطا معلبا في قوالب جاهزة إلى شعر نافخا فيه روحا جديدة من الأصالة والجزالة وقوة المتن لفظا ومعنى، كما انتقل العباسيون بشعرهم من البداوة التي كانت جاثمة في العصر الأموي إلى حضارة العصر العباسي. ومن ثم وجد البارودي في الشعر العباسـي تجربـة نـاجزة يلتحم فيها التراث بالحداثة، أو القديم بالجديد، فهي لا تكف عن الانفتاح على الذاكرة الحداثية المعاصرة مع الارتداد إلى تراثها.

ولكن هذا المنهج الذي اختطه البارودي لا يعني أنه ألغى ذاته أو همشها، إذ

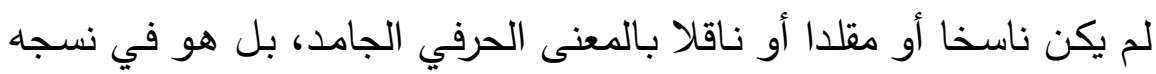
على منـوال السـابقين كمن ينسـج على أسـنة الرمـاح وينقش على صفحات السيوف، ويمتح من معين النصوص السابقة ماء حياة لخلق جديد، فهو في مراهنة لا ينتظر منها إلا النجاح والتحليق، إذ كان يحاور النصوص السابقة ويشاكلها حتى تمتزج وتترسخ في أعماق وعيه لينتج لنا نصا جديدا يتجاوز آفاق النصوص القديمة. وهذا ما أشار إليه الدكتور عصفور في موضع آخر قائلا عن البارودي: "إنـه كان حريصـا على منافسـة القدماء، حتى لو كان يجري في مضمارهم، ولذلك كانت علاقته بهم تتطوي على معنى المنافسة الذي كان يبرز فعله بالقياس إلى فعل من كان يقوم بمعارضته.... صحيح أن البارودي لا يمارس قتل الأب التراثي التي أشار إليها أبو تمام في قوله:

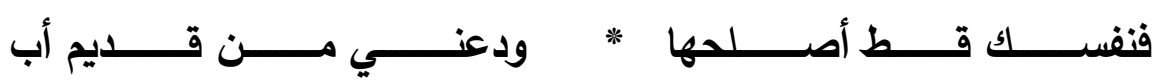


ولكنـه كـان يستهل الخطـوة الأولى في تقويض سطوة هذا الأب وسـلطته

القاهرة بإعلان التفوق عليه، والمجاوزة لأفعاله"( )

ويرى العقاد أن ما كان من معارضة البارودي للقدماء إنما هو معارضة محكمة مطبوعة، ليس فيها من التقليد إلا الرغبة فيه؛ إذ إن البارودي "فنان خالق في اتباعه كما يكون المرء فنان خالقا في ابتداعه... وفرق بين هذا التقليد وتقليد العاجز المتكلف الذي يظلع في آثار القادرين بغير أداة المعارضة والمجاراة.

ولهذا بزغت مقومات "الثخصية" البارودية من وراء حجب الأوضاع وأعباء العرف والاصطلاح، فعرفنا الرجل من شعره على صورة كالتي عرفناه بها في

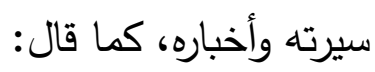

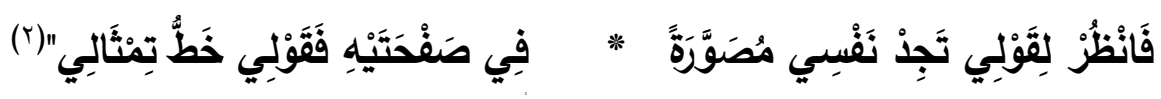
ويعود (د/شوقي ضيف) ليؤكد أن البارودي لم يكن مقلدا إلا في الإطسار الخارجي، أما فيما عدا ذلك فروحه وشخصيته بارزة واضحة متألقة، فيقول: "فالبارودي إنمـا يستعير من القدماء إطلارهم الذي يقوم على قوة الأسلوب وجزالته، ولكنه يملأ هذا الإطار بروحه وبشخصيته، وكأنه خاتم يطبع على إلى الته

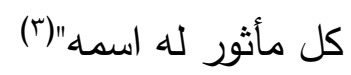

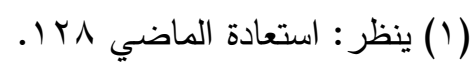

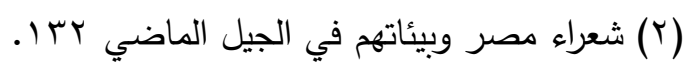

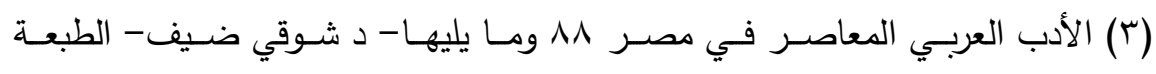

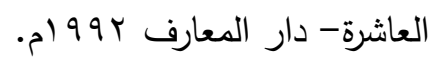


ومن ثم رد البارودي بذلك "إلى المعاصرين يقين القدرة على مجاراة العباسيين والمخضرمين والجاهليين في ميدان اللغة والتراكيب"( (). ولكن البارودي لم يكتف بإظهار المعارضـة، بل صدع في كثير من شعره بتفوقه على الآخر (القدماء)، فحينما قال عنترة العبسي: [من الكامل](؟) هـل غـادر الثـعراء مـن متـردم * أم هـل عرفـت الــار بعـد تـوهم عارضه البارودي بقوله: [من الكامل](")

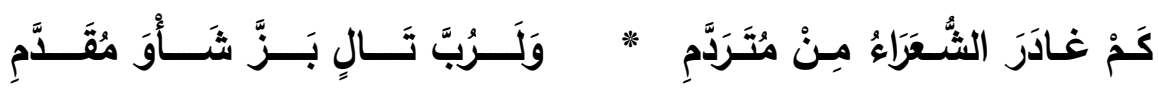
ليضـع جدلية هدم وبناء في آن معا، هدم يرفض أيديولوجية الفكر العنتري

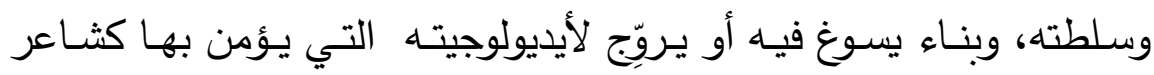

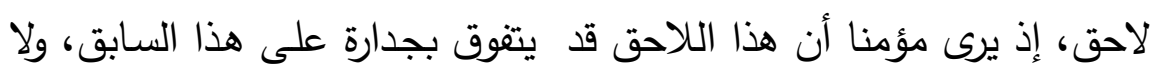
يمنعن من ذلك مانع؛ إذ إن منادح القول مفتوحة ومستمرة لم يأت الشعراء

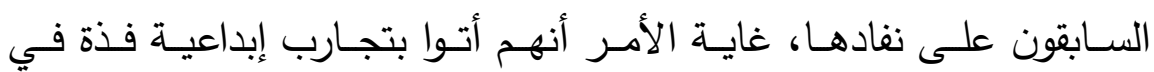

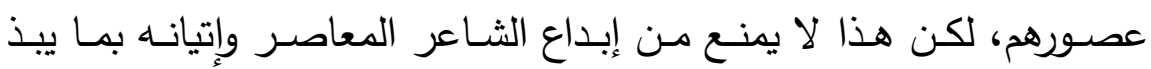
تجاربهج متى امتلك الأدوات الفنيـة التي تعينـه على ذلك، حتى ولو ألفت الذاكرة ترديد حكم المتنبي وغزليات امرىء القيس وخمريات الأعشى ومواجد

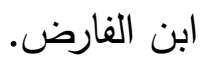

(1) شعراء مصر وبيئاتهم في الجيل الماضي ^ــا.

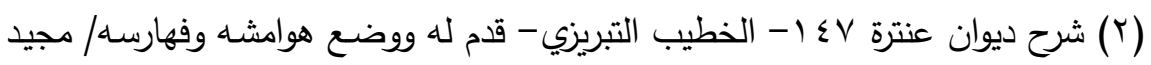

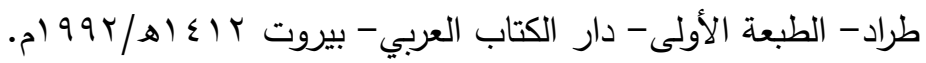

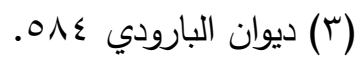


وهذا ما أثار إليه البارودي في البيت الذي يلي البيت السابق، حينما قال:(') فِي كُلِّ عَضْرِ عَبْقَريُّ لا يَنِي فيلجأ إلى الرمز لإثبات تفوقه على السابقين، فالعبقري المجهول الذي ظهر في عصر البارودي ونوه به وأومأ إلى قدرته الشعرية الخارقة، إنما هو البارودي نفسه، ف "صفة "العبقرية" وما يشتق منها أصبحت تستخدم استخداما رمزيا لإضفاء صفة التقوق على الأمر المتعجب منه، وليس بالضرورة أن يكون المقصود ربط الموصوف بأسطورة جن عبقر المعروفة، فأصبحنا نسمعه يقولون: عبقري المعاني، وعالم عبقري، وهواي العبقري، والنهم العبقري، والجمال العبقري، وعبقري الضياء... إلخ"(r) وهذا ما يدفع عن شاعرنا شبهة التقليد الأجوف أو التبعية العمياء، فما كانت رغبته في المنافسة إلا أن يكون لله قصب السبق في الإبداع، فيكون الرائد المتبوع لا التابع، لا سيما وأنـهـ يصور تلك المنافسة في صورة حلبة سباق لهاق يود فيها كل فارس الفوز والغلبة على قرنه ونده، مما يعطي لنا مؤشرا مهما بأن معارضات الرجل نابعة من هذا الفكر وصسادرة عن هذا المفهوم الذي لا يغيـب عـن وعـي البـارودي الطـامح وروحـه الرافضــة للإمعيـة المرذولـة أو الببغائيـة الناعقـة، ونفسـه الواثقــة المتوثبـة للتحـدي والفروسـية والاسـتطالة

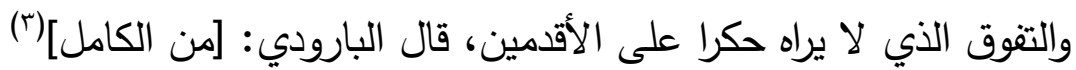

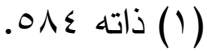

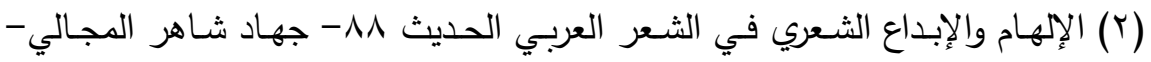

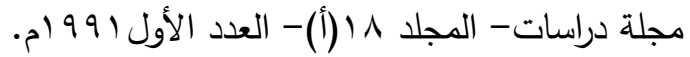

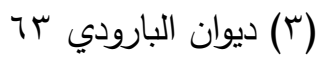




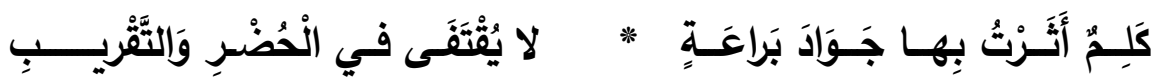

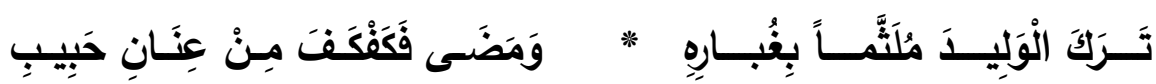
فنراه - من خلال وضع القصيدة في علاقة تثابه مجازية بهذا الجواد الذي يضرب بعيدا في عمق الزمن يتحرك من الحاضر إلى الماضي منسحبا إلى فئ

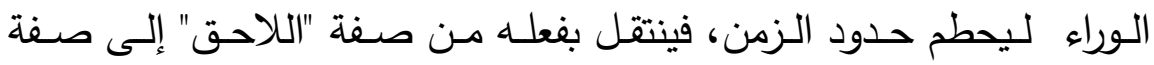

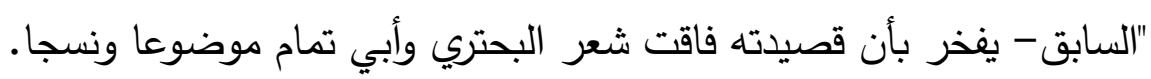
ولا أدل على استدارته للماضـي ومعاكسته حدود الزمن من جعل الثعراء

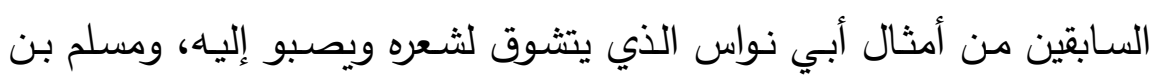

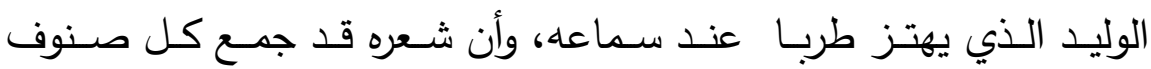

المحاسن التي لم تجتمع لشاعر قبله، فيقول: [من الكامل]"(')

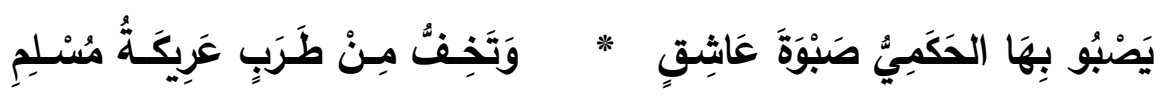

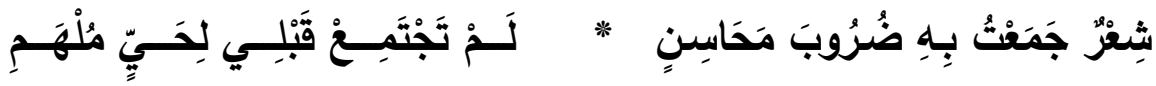
فتراه استعمل في البيت الأول الفعل المضارع مرتين "يصبو" و "تخف" ليحقق

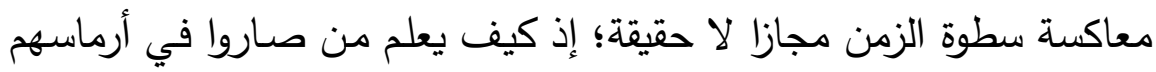

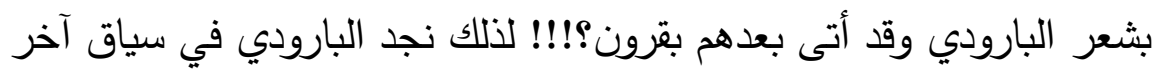


يعول على الفعل الماضي ولكنه ساق الكلام في إطار الثرط الذي حال دون تحقق الجواب نظرا لامتناع الفعل، وذلك في قوله: [من الطويل](')

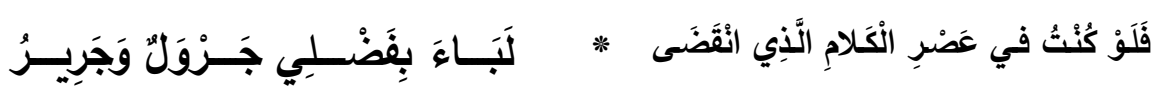

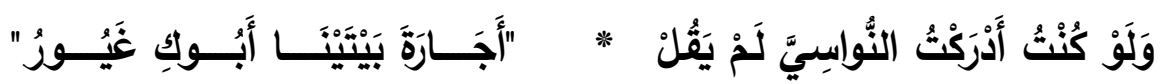

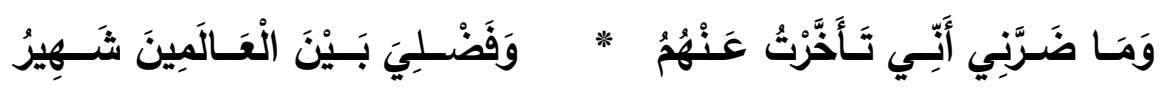

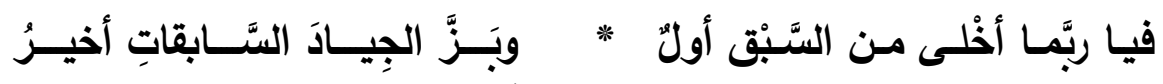
إذ يعلن في غير مواربة أنه تمكن من رياضة القريض بحيث لو قيض له أن يكون في حلبة منافسة مع من سبقوه من فحول الثعر في تلك العصور من أمثال الحطيئة وجرير في العصر الأموي وأبي نواس في العصر العباسي لأقر بفضله أولئك الأعلام، وساروا تحت لوائه طائعين على الرغم من تأخر

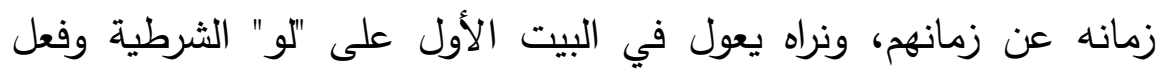
الشرط "كنت في عصر الكلام الذي انقضى" وجواب الشرط "باء بفضلي جرول وجرير، وكذا في البيت الثاني يعتمد على الأداة نفسها مع تكريرها، وفعل الشرط "كنت أدركت النواسي" وجواب الشرط "لم يقل أجارة بيتينا" إذ يشير أسلوب الشرط في الموضعين إلى عدم تحقق الوجود أو الحضور ، لذا امتتع وجود الجواب في الموضعين، ثم يستخدم النفي في البيت الثالث لينفي أنه غير متضرر من عدم وجوده في عصور هؤلاء، أو أنه تأخر عنهم زمانا، لكنه سبقهم في المكانة والإبداع، وهنا تظهر براعة البارودي في تمرير 
الإقناع على العقل ليقبله ولا يحاججه، فيبرهن على قوله بالمنطق أو بالتشبيه الضمني في البيت الأخير الذي ساقه في إطار من الرمز الرائع، إذ يرمز بالأخير السابق من الجياد إلى نفسه قاصدا تفوقه واستعلاءه. ويلحظ في البيت الأول أنه جمع بين شاعرين من العصر الأموي دون أن يذكر شيئا من شعرهما، في حين اقتبس في البيت الثاني الثطر الأول من مطلع رائية أبي نواس الذائعة في مدح الخصيب بن عبد الحميد أمير مصر في عهد الرشيد: [من الطويل]' (')

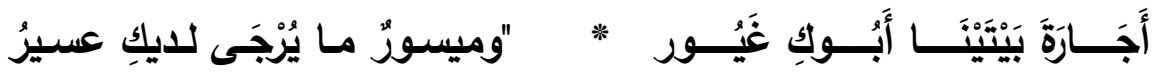
ولعل هذا يؤكد تأثره بالثـعر العباسـي دون الأمـوي، إذ لـ يعـارض جريـرا والحطيئة، في حين عارض قصيدة أبي نواس ذات المطلع السابق بقوله:(؟)

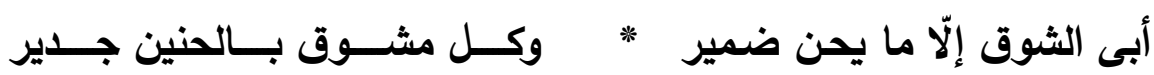
ويرد في الوقت ذاته ما قاله د/ جابر عصفور من أن هذين البيتين - الأول والثاني- "لا يقصران الانتساب الثعري على العصر العباسي، بل يمتدان بالنسب إلى العصر الأموي الأقدم"(־) وأكاد ألحظ أن البارودي في أبياته السابقة متأثر بابن زمرك الثاعر

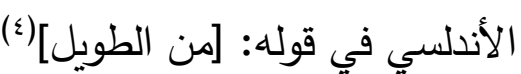

$$
\begin{aligned}
& \text { (1) ديوان أبي نواس • ^ــ. } \\
& \text { (Y) (T) }
\end{aligned}
$$

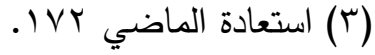

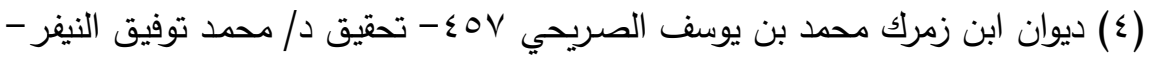

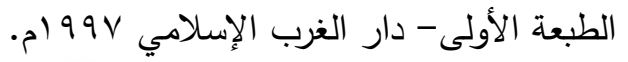


ولو أنني أدركتُ أعصارَ من مضى * لمـا قـال فيهـا الثـاعر المتخايـلُ

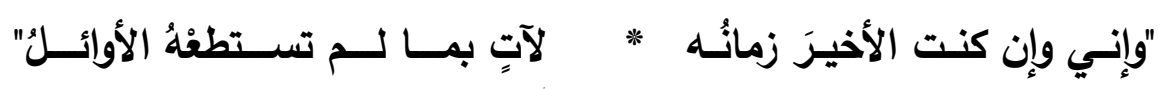

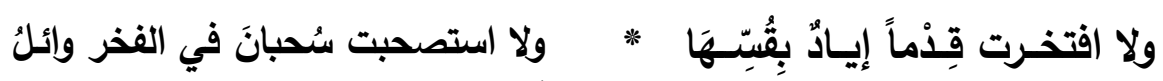
وربما عرف فيه صديقه شكيب أرسلان هذه النزعة العنترية التي لا يتغيا من ورائها إلا الفوز ولا يجني من جرائها إلا الظفر ، فراح يمدحه بما يوافق طبيعة

نفسه، قائلا: [من الطويل] (')

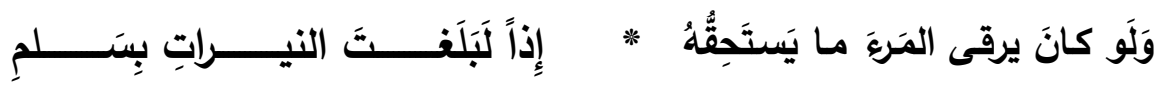

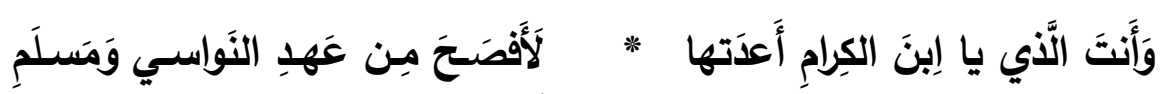

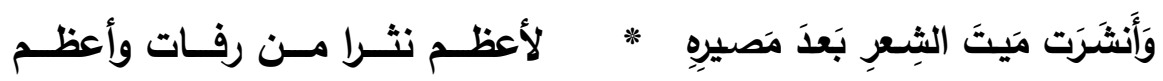

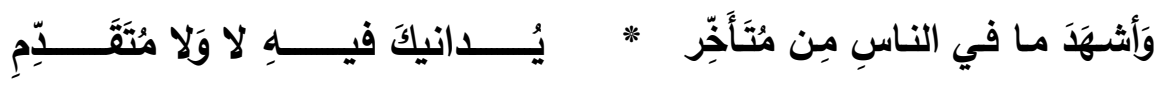

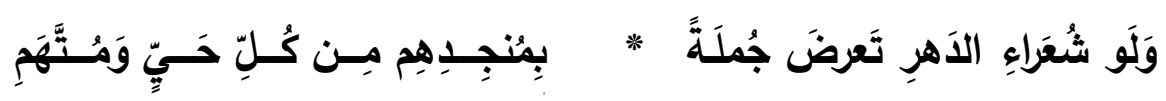

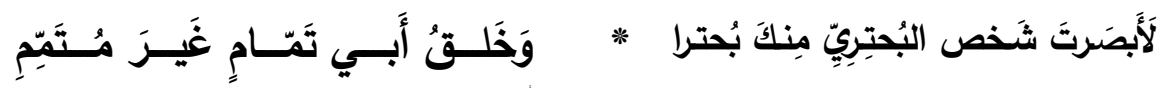
(1) ديوان الأمير شكيب أرسلان ج- وقف على طبع القسم الأكبر من هذا الديوان السيد

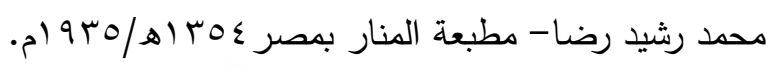


ولا يزال البارودي يتغنى بتلك النغمة التي لا يكف عن ترديدها، وهي تصوير

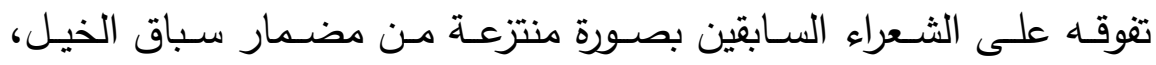
فيتسـاءل متعجبا، لم لا تسبق بديهته أربـاب اللسـن والمقاويـل في العصسور السـالفة، والرمـاح السمهرية تخاف البطش والفتك من قولـه!!! ثم يؤكد أن لكل زمان رجاله الذين لهم من البصمات ما يجعلهم غرة في جبينه فلا يُعرف العصر إلا بهم، فالفضل ليس بقدم الزمان أو حداثته، وإنما الفضل بالنفس،

$$
\text { فيقول: [من البسيط](') }
$$

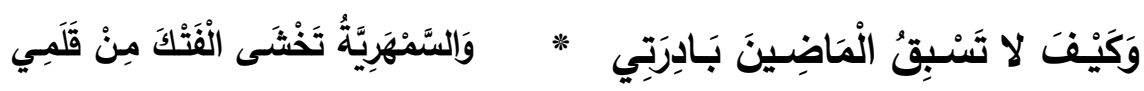

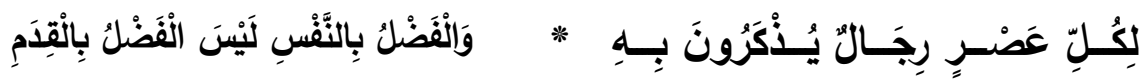
ولعل وضع الباروديّ القصيدةَ في علاقة تثابه مجازية بالفارس أو الجواد كان وراء ربط الثعر بالفروسية لديه في كثير من شعره، يقول البارودي:

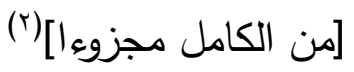

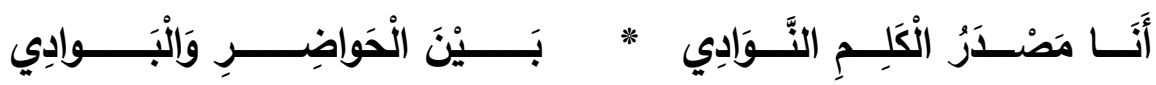

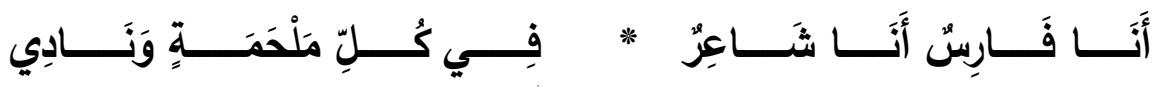

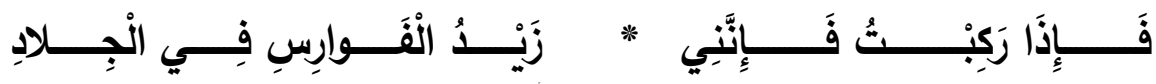

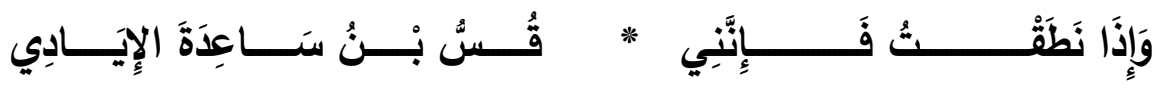




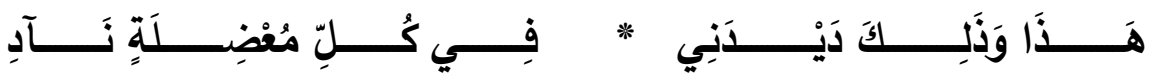

والحق أن البارودي كثيرا ما يمزج في فخره الحديث عن شعره وفروسيته، فهما أهم صفتين عرفا بهما حتى لقب "رب السيف والقلم"

ومن ينعم النظر هنا في الأبيات يجد أن الثـاعر قدم فخره بشاعريته (أنـات مصدر الكلم البوادي) على فخره بفروسيته (أنا فارس) وهذا يشف عن مدى الثى تأثير الثعر في نفسه أكثر من تأثير الفروسية، فهو شاعر قبل أن يكون فارسا، لكن الصفتين - الشعر والفروسية- لا ينفكان عن بعضهما، بل هما متلازمان؛ ولذلك قال: "هذا وذلك ديدني" ومن ثم فـلا عجب أن تعلو أنـاه المتاعظمـة المنتفشـة هنـا، كمـا لا عجب أن يشبه الثـاعر نفسـه في البيان والفصـاحة بقس بـن سـاعدة الإيـادي وهـو مـن أبـرز خطبـاء العـرب في هـي

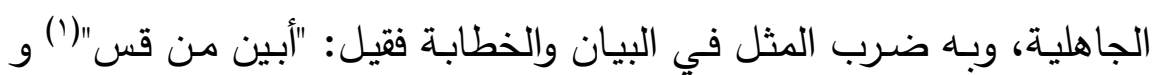
"أخطب من قس"(ז) وفي الفروسية بـ "زيد الفوارس" وهو زيد بن حصين بن ونـ

ضرار الضبي، أحد الفرسان الثعراء في العصر الجاهلي (). بل يكرر أداتي الشرط وفعلي الشرط مـع اختلاف الجوابين في موضـع آخر ،

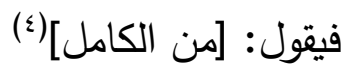

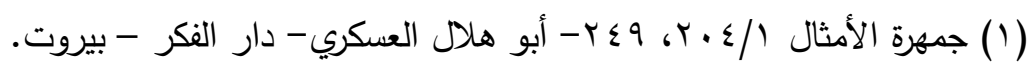

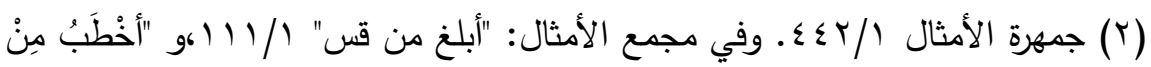

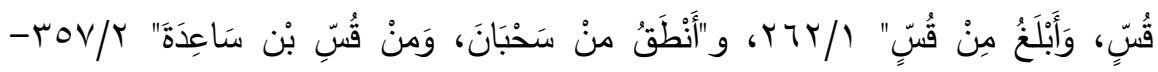

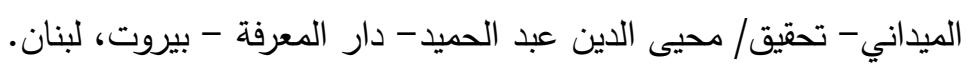

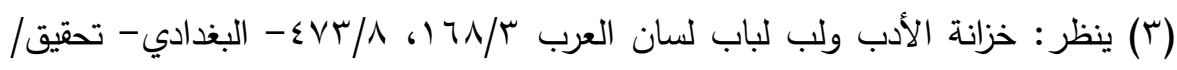

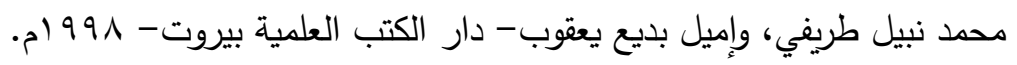

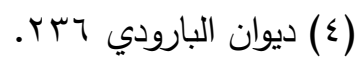




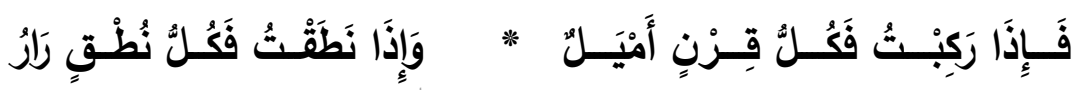

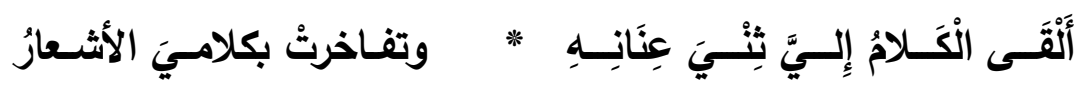

$$
\text { وفي هذا المعرض يقول أيضا: [من الطويل]|'(') }
$$

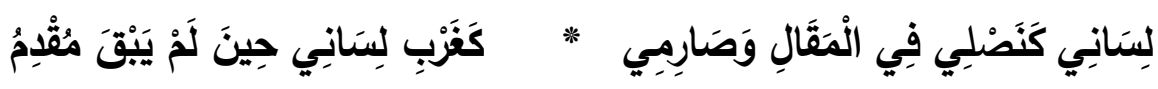

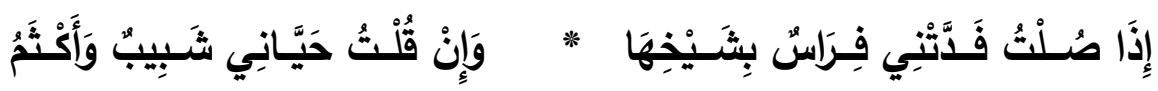

$$
\text { ويكرر هذا الربط في قوله: [من الطويل](؟) }
$$

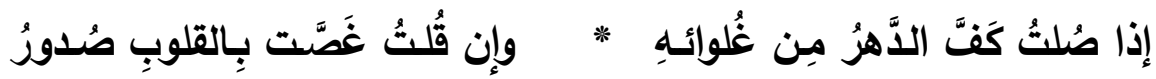

$$
\text { وفي قوله: [من الطويل](ץ) }
$$

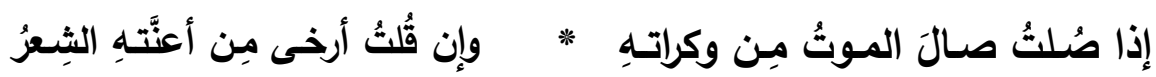

$$
\text { وفي قوله: [من الطويل][() }
$$

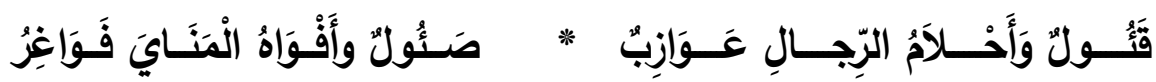

$$
\begin{aligned}
& \text { (1) ديوان البارودي V• •T. }
\end{aligned}
$$

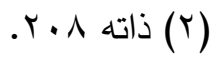

$$
\begin{aligned}
& \text { (ז) ذاته } \\
& \text { (乏) ذاته }
\end{aligned}
$$


وفي قوله: [من الكامل](')

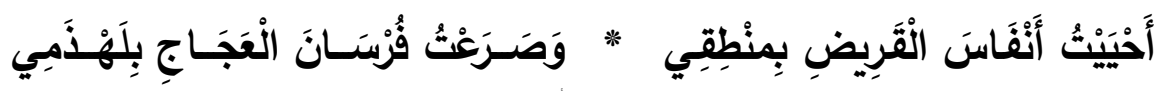

بل يكرره في القصيدة نفسها في قوله: [من الكامل](ז)

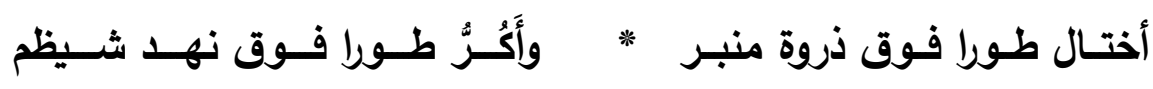

وقد يكون تعويل البارودي في جانب شجاعته على "إذا الشرطية" وفي جانب شاعريته (القول) على "إن الشرطية" لأن الثجاعة سابقة في الوجود لديه من

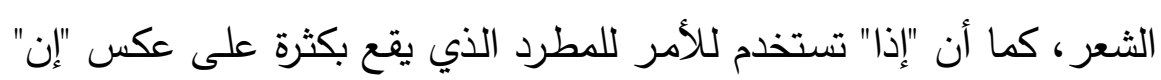

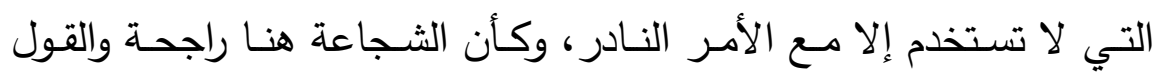

مرجوح.

ويظل شـاعرنا آخذا بأسلوب الرمـز الثـعري في مواقف تعبيريـة مختلفـة،

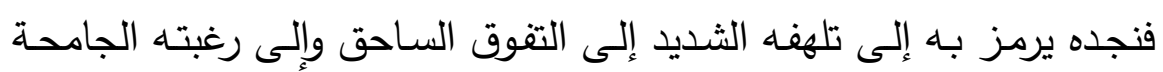
الطامحة في الإتيان بالخوارق الباهرة حتى يصف الفتى الفذ الذي يرى فيه

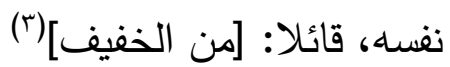

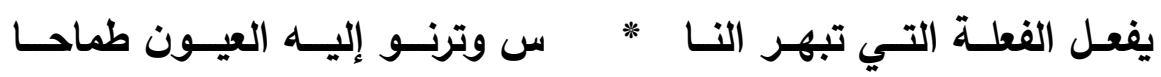
ثم نراه يزهو بتقديمه على الرغم من تأخر زمانـه عن السابقين، فيقول: [من

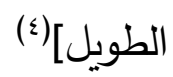

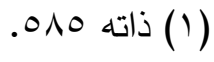
داته (r) داته (r)

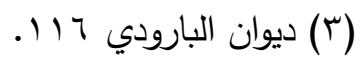

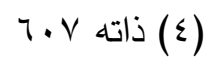




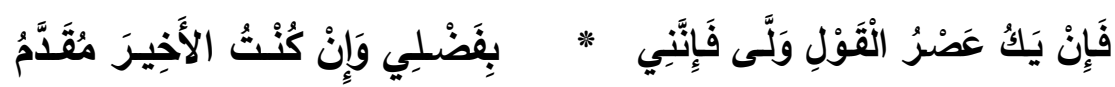

وهو هنا كأنه ناظر إلى قول أبي العلاء المعري: [من الطويل]|'(")

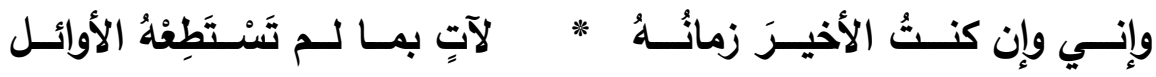

على ما بين البيتين من تفاوت، إذ تشعر في بيت العلائي تحديا ووهجا حماسيا ملحوظا في حين تثعر في بيت البارودي بنتور وخمود. الموقف الثاني: موقف موجه إلى معاصري البارودي أو من أتى بعده: ويتبدى هذا الموقف من خلال استعلائه والزهو بثعره، وحث الناس أن يتغنوا

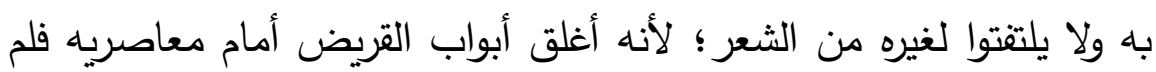

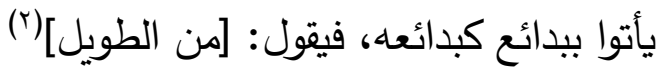

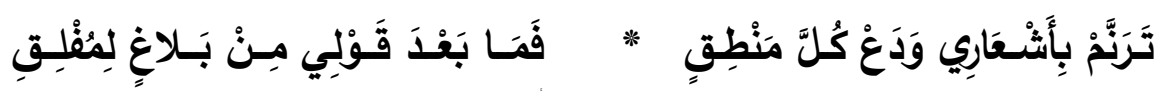
فجدلية الأخذ والرد، أو القبول والرفض التي يريد من المتلقي ممارستها نابعة

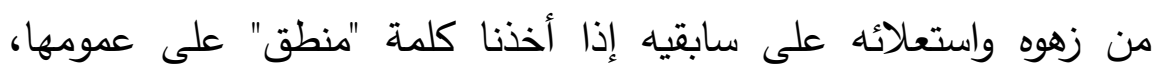

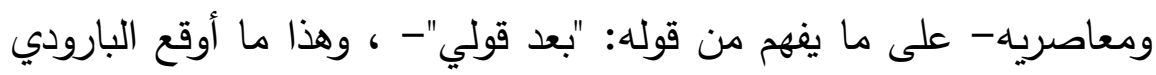

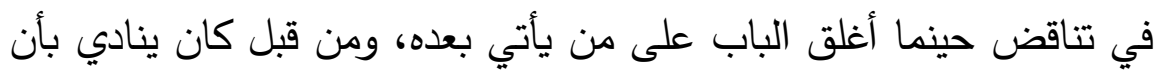

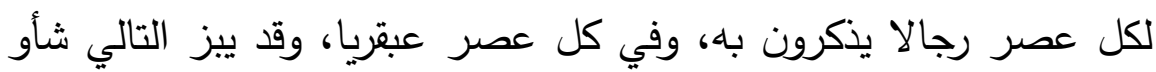
المقدم، وكذا الأخير يبز السابقات من الجياد.

(1) سقط الزند بو 1 - أبو العـلاء المعري- دار بيروت للطباعـة والنشر - دار صـادر

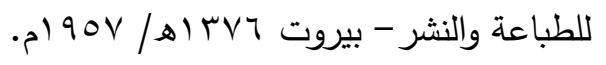

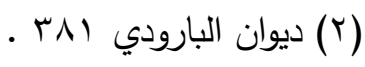


بل إنه في خاتمة القصيدة يرى أنه حقق طموحه وغايته من خلال شعره، حيث تفتقت قريحته بالبدائع التي لم يسبق إليها، ولم يدع بابا من أبواب الثعر إلا طرقه، ثم يصور شعره بينبوع الماء الصافي الذي يدعو الثعراء ليرتووا منه، إن أرادوا أي يحققوا لأنفهح مكانة في دنيا الثعر، فيقول: [من

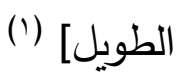

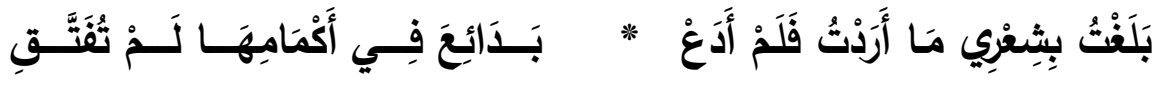

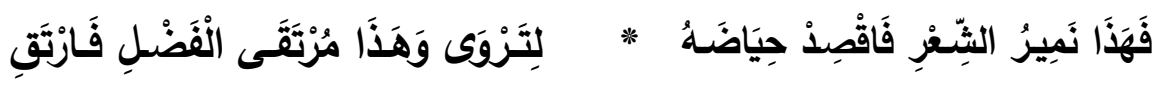
ولا يزال مزهوا بشعره معجبـا بـه مؤكدا أن الناس لا يستطيعون أن ينسـوا

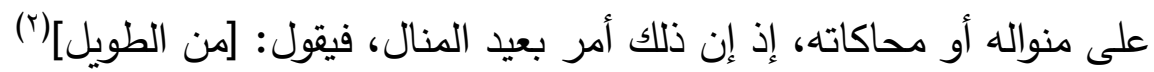

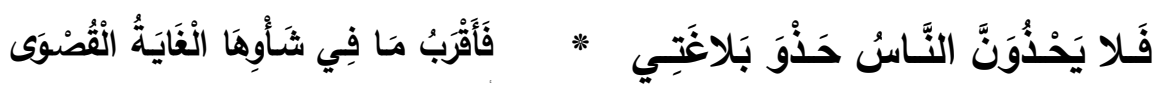
ويلجأ إلى هذا الزهو والثموخ بشعره فيكني بنصاعة بيانه وقوة حجته بسانه المرهوب، ويكني بإثارة اهتمام البدو والحضر بشعره بتسعير اللظى بينهما،

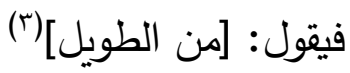

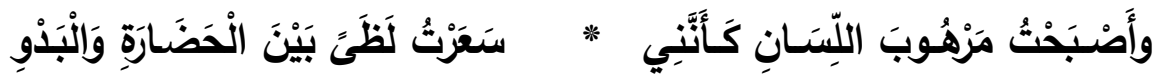

$$
\begin{aligned}
& \text { (1) ذاته ایمس وما يليها. }
\end{aligned}
$$

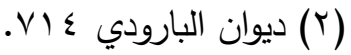

$$
\begin{aligned}
& \text { (r) ذاته } 919
\end{aligned}
$$


ثم يبني على هذ البيت قضية التيه والعجب، ويعجب من هؤلاء الذين يريدون أن

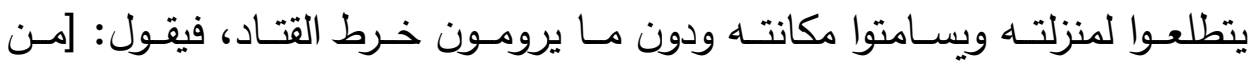

(الطويل[ (1) (2)

فَيَا عَجَبَاً للِفَقَوْمِ يَبْغُونَ خُطَّتِي

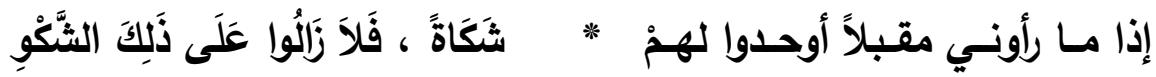

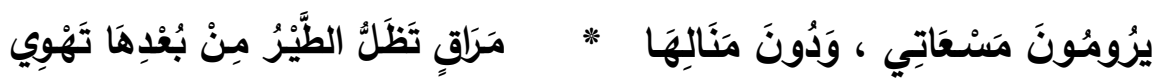
وانظر إلى جمال الصورة في البيت الأخير حين يصور مكانته العالية وعجز القوم عن نيلها لارتفاعها وسموقها، حتى إن الطير لو حلقت في الأجواء واتخذت أجنحتها معارج للوصول إلى مكانته فلن تستطيع لبعد هذه الهوة، ولسقطت من علٍ. وأكاد ألحظ هنا أن البارودي في قوله: "فلا يحذون الناس حذو بلاغتي.. إلخخ، وقوله: "يرومـون مسعاتي إلى آخره، نـاظر إلى قول البحتري: [من (الطويل]

بــائع تــأبى أن تــدين لثــاعر * سـواي إذا مـا رام يومـا يقولهـا 
وكعادته في التعليل والبرهنـة يسوق لنا الحجج الإقناعية في تفاوت المنزلة بينه وبينهم في صور تضـادات واضحة أو سياقية، ليبين لهم أنهم دونهه في المكانة، فيقول: [من الطويل] (')

وَلا، وَأبي ما النصلُ في الفعلِ كالعصدا * وَلا القوسُ ملآنَ الحقيبةِ كالخلوِ

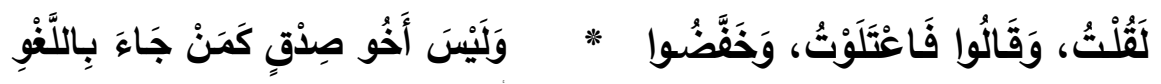

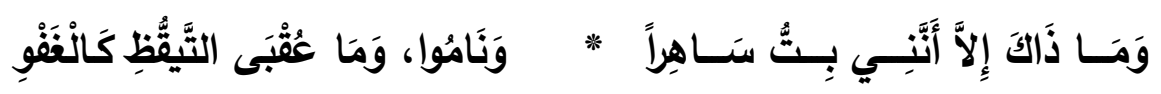

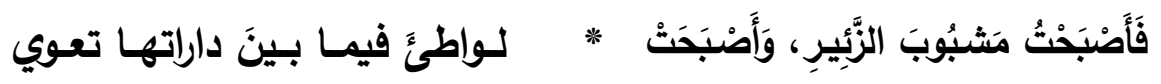
ففي البيت الأول يعمد إلى القسم بوالده، ليؤكد صدق دعواه، فالنصل الذي يرمز به إلى نفسه في حدته المسنونة ليس كالعصسا التي يرمز بها إلى غيره في الضعف وقلة التأثير ، وكذا القوس في حال امتلاء كنانتها ليست كالخالية من النبل، وهو يشير في حـال امتلاء كنانـة القوس إلى نفسـه، وفي حال خلوها إلى غيره ممن يريدون أن يتطلعوا لمكانته. وعلى هذا النحو تمضسي الأبيات على نمط التضـادات المشفوعة بالحكمـة التي تحمل في طياتها

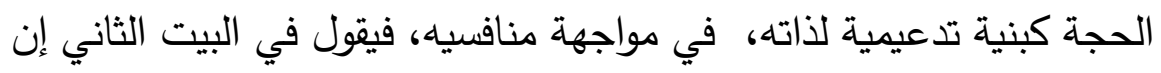
ثمة تباينا بين ما يقوله وما يقوله منافسوه أو حساده، فبينما يتبع الصدق في أقوالـه ويترفع عـن اللغـو والفضـول صـار غيره في الحضـيض الأوهد بمـا

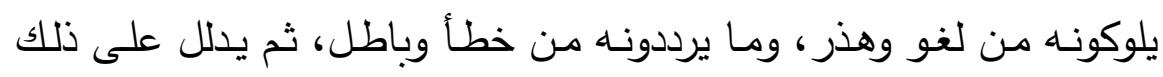

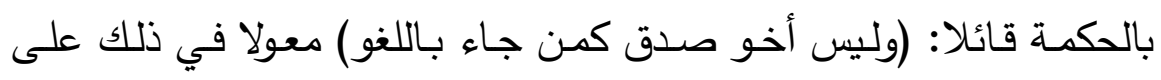

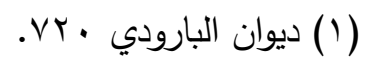




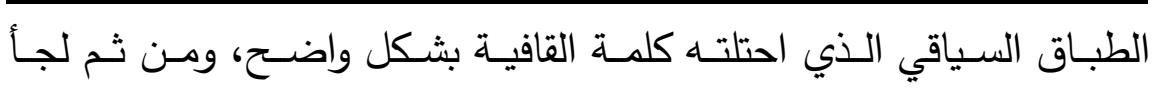
البارودي إلى الانزياح، وعدل عن كلمة "الكذب" التي تضاد الصدق من أجل

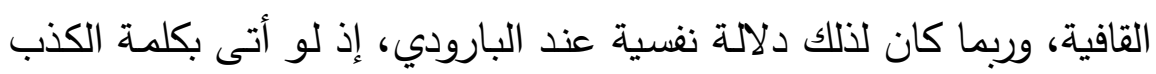

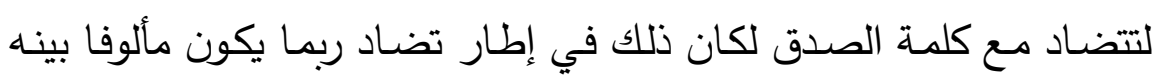
وبين منافسيه، أما وقد لجأ إلى كلمة (اللغو) ليؤكد أن المعادلة غير متكافئة بينها وبينهم. ثم يأتي البيت الثالث تعليلا لما قبله يحمل في طياته كنايات متضادة فكنى بسهره عن جده واجتهاده، وكنى بنومهم عن توانيهح وخلودهم إلى الدعة، ثم يردف ذلك بالحكمة (وما عقبى التيقظ كالغفو) على غرار ما

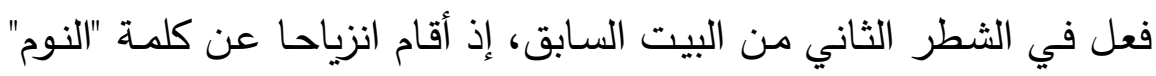

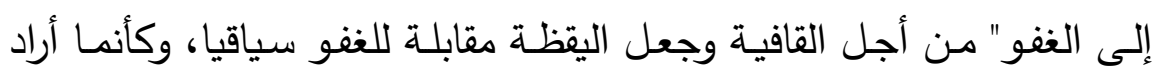
البـارودي أن يظهـر وفـرة معجمـه الثـعري في اسـتعمال الألفـاظ، فالسـهر واليقظة من حقل دلالي واحد، وكذا النوم والغفو من حقل دلالي واحد. ثم يأتي البيت الأخير نتيجة يعلنها الثاعر الذي جعل نفسه حكما، فيظهر فوزه مكنيا بذلك عن قوته ونباهة شانه وشدة بأسـه في قوله: "فأصبحت مشبوب

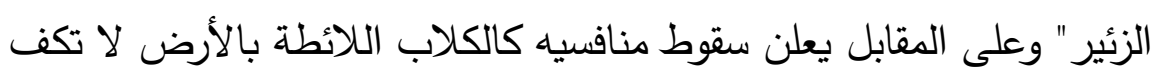
عن العوي.

ثم ها هو ذا يأمر معاصريه - مدن أراد الإملمام بشيء من عظمة بيت الخديوي إسماعيل - أن يطالعوا شعره في مدح ذلك البيت، وليتخذوا قصائده سلما يرقون بـه إلى معرفة هذا البيت المنيف ببنائهه وبصاحبه، فيقول: [من من

(الطويل] (1) (2)

$$
\text { (1) (1) (1يوان البارودي Vro وما بعدها. }
$$




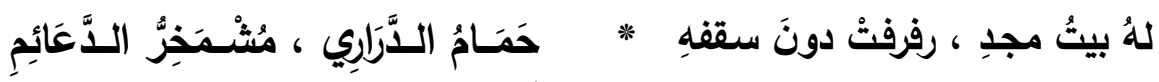

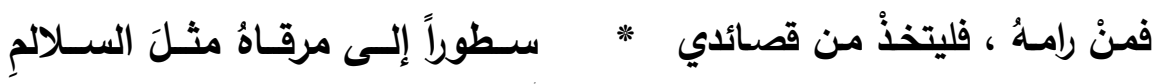

وقد يجمع البارودي تفوقه على السابقين واللاحقين في موضع واحد، وكأن تضخم الأنا الثعرية وتعاظمها لديه قد دفعه إلى توسيع دائرة تفوقه على الآخر حتى شملت البرية أجمعين كما في قوله: [من الطويل]"(') مخـدرة تمحسو بأذيـال حسـنها أساطير من قبلي وتعجز من بعدي

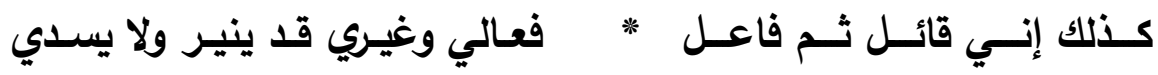
فنراه يشبه قصيدته بالفتاة المخدرة كناية عن تسترها، ثم إنها ذات جمال بارع بأقل شيء منه تمحو أباطيل السابقين، وفي الوقت نفسه أعجزت اللاحقين، وقد لعب الطباق دورا رائدا في توسيع دائرة تفوقه على الآخر (قبلي/ بعدي)،

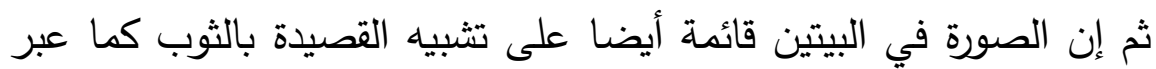
اللازم "أذيال" عن ذلك، وكما يعضد ذلك تلك الحجة التي يسوقها البارودي على دعواه في البيت الثاني بأنه إذا قال فعل، أما غيره فلا يستطيع النسج الصحيح للثوب، فمرة قد ينسج لحمته خلاف سداه، وأخرى ينسج سداه خلاف لهاه لحمته، ولعل هذا يشير إلى إحكام البارودي لشعره الذي يرتد إلى عملية 
الصنعة - من وجهة- كأن هذا الشعر ثياب ينبغي أن تحاك حوكا جيدا،،، رحم الله "ابن ميادة" حينما قال: [من الوافر](')

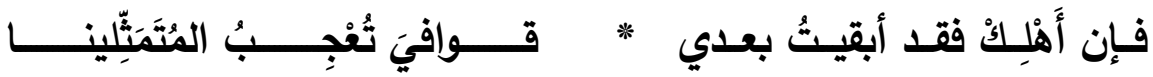

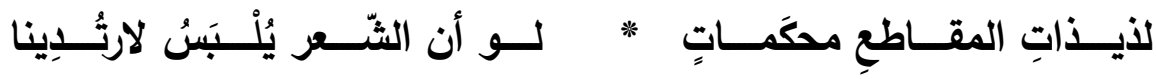
ولعل في تصوير البارودي قصيدته بالفتاة المخدرة يستلزم بكارتها، التي لم ينص عليها صـراحة في شعره كمـا نص غيره مـن السـابقين في وصـفهم قصـائدهم البكـارة أو العذريـة، وهـا ينطـوي على بعـد فكري يبـرز اعتـداد الثاعر بالجدة والابتكار والانطلاق في آفاق الفن.

ولكن السؤال الذي يطرح نفسـ: ما السر وراء تلك الأنـا المتعاظمة في إبراز التفوق على الآخر سابقا ولاحقا (معاصرا)؟ أغلب الظن أن ذلك عائد إلى: 1- إحساســه بالعظمـة والمقدرة الفائقتـة في السـيف والقلـم، فهو رب السـيف والقلم بين مصريين مستضعفين وبين حكام من الأتراك والجراكسة يلتوي لسانهم عندما ينطقون كلمة عربية واحدة.

Y- إحساسـه بالمسئولية في بدايـة عمره، فقد نشـأ يتيما، ونصَّبَتْهُ أمسه رجـلا للبيت وهو في ميعة صباه، وألقت عليه دروسا يتعلم منها العظمة والعزة، هذا إلى جانب مـا سردته على مسـامعه من بطولات الأسرة وأمجادهـا لتشحذ في نفسه التطلع إلى مراقي المجد والسؤدد.

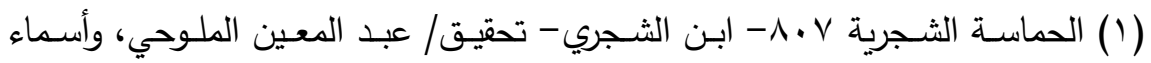
الحمصي، منشورات وزارة الثقافة بدمشق • ل أم. 
ب- تأثره بشـر الثـعراء الفرسـان الذين كانوا يبالغون في فخرهم بأنفسهمح وشجاعتهم وقدرتهم الفائقة في القتال، فترسم البارودي طريقهم وتقدص أدوارهم وحاكى فعالهم.

ع - عدم استساغته "أن يكون تابعا لفرد من أفراد الأسرة الخديوية، تلك الأسرة

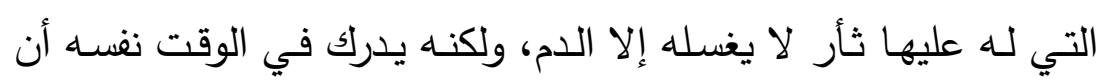

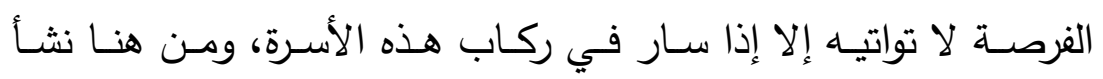
التـاقض الكبير لايـه، بين اللاشعور الذي يفرض عليـه أن يسير في لإني

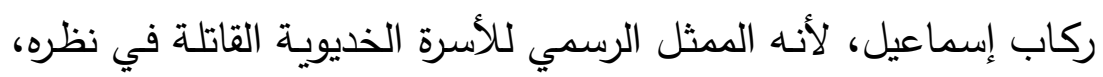

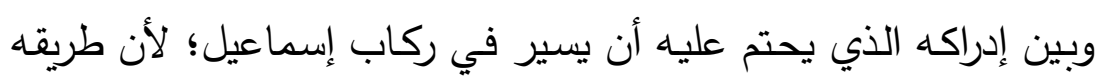

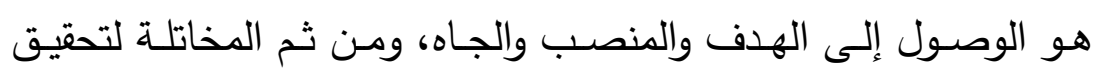
الهدف، ... فلعب لعبة مزدوجة لتحقيق أهدافه بين إسماعيل وتوفيق من

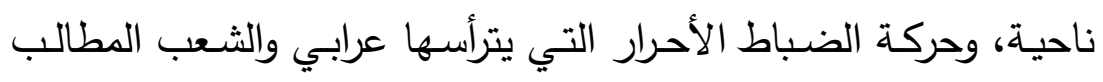

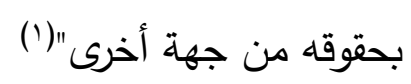

ه- إيمان الشاعر بأن ثمة تفاوتا بين الناس، في قوله: [من البسيط](؟)

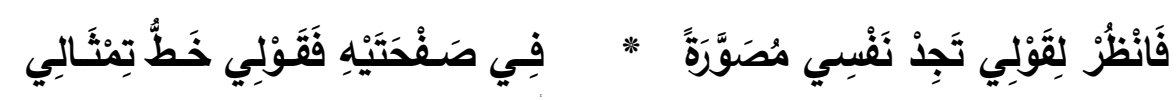

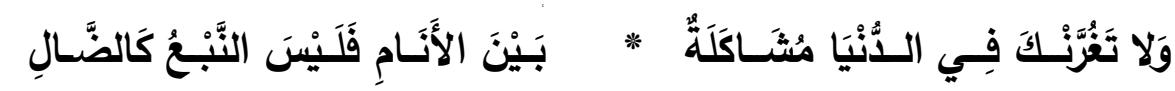

وفي قوله: [من البسيط](ץ)

(1) نفسية البارودي من خلال شعره 7 ـ ب وما يليها- عمر محمد- مجلة آداب الرافدين-

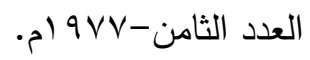

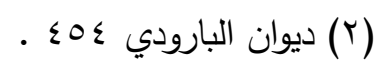

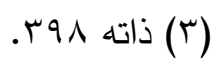




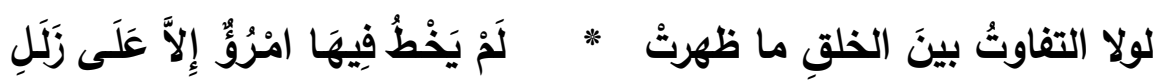

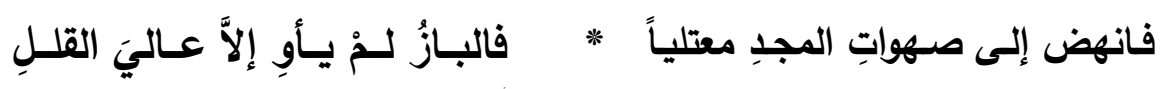

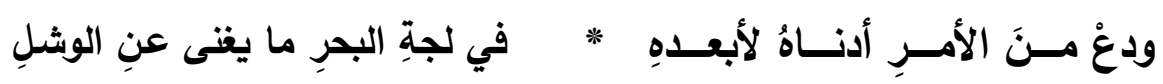

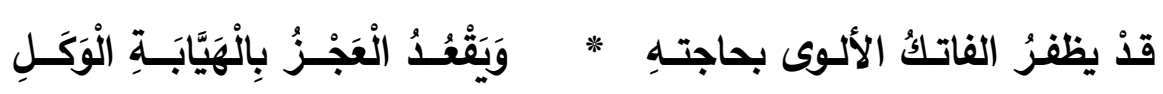
فالباز في الأبيات ما هو إلا رمز لمعنى العلو والرفعة أو رابط سيميائي بين

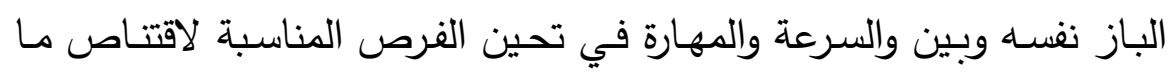

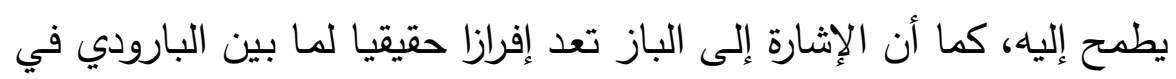
ترفعه وسموقه وبين الجبناء من بني وطنه في تخاذلهم وانكسارهم. وتأكيدا على فكرة التفاوت بين الناس يقول: [من الكامل][(1)

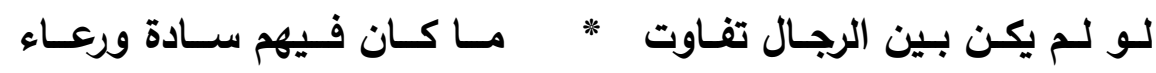
7-وربما كان ذلك الأمر عائدا لإحساس البارودي بعلو نسبه وفخامته، كما

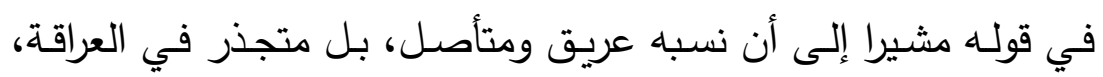

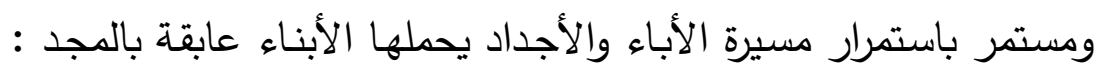

$$
\text { (ب)[من الطويل] }
$$

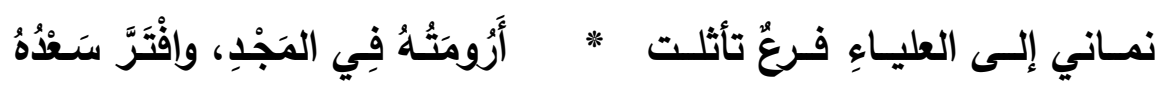




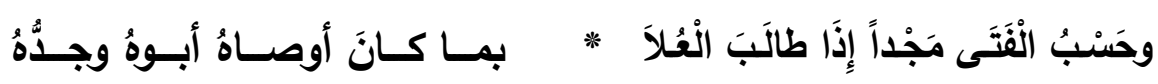

ثـم يلفــت أن المجـــ لا يحمـــه الرعـاء، وأن الأمـور العظيمـة لا تصــلح إلا لعظماء الجدود، فيقول: [من الخفيف تاما](')

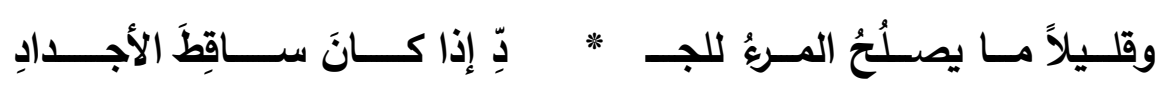
ويلح على أنه دن معشر كرام أعزة لهم بصمات في التاريخ بما يشهد لهم بالثرف والمجد، الذي وصلوا إلى ذروته بشجاعتهم، فيقول: [من الخفيف

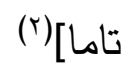

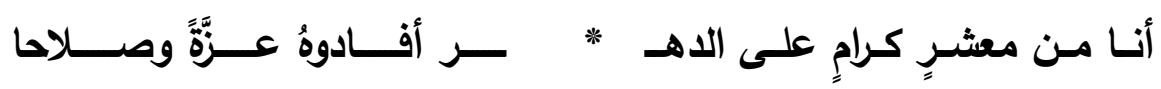

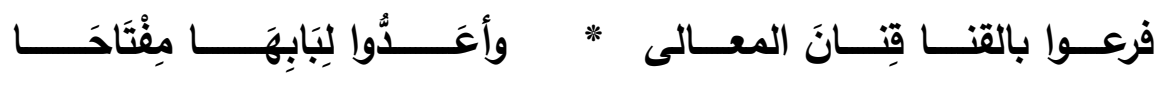
ولا أدل على ذلك الدافع من أن البارودي يمزج بين عراقة نسبه وفخامته وبين

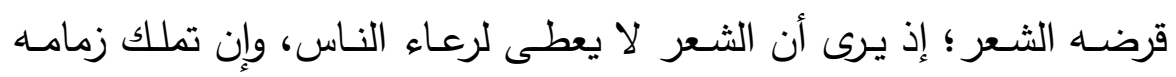

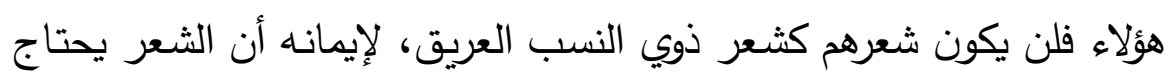
إلى العراقة والأصالة والخصال الكريمة والحرية التي لا تكبح جماح شاعرها، فيقول: [من السريع] (r)

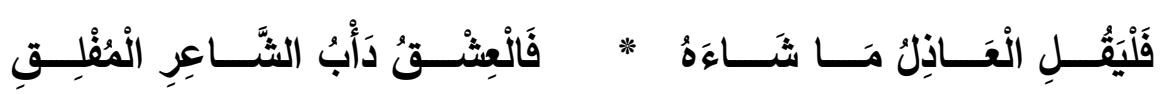
(1) ذاته

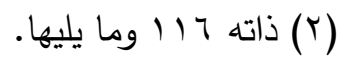

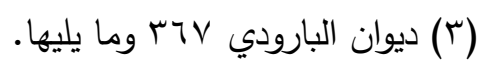




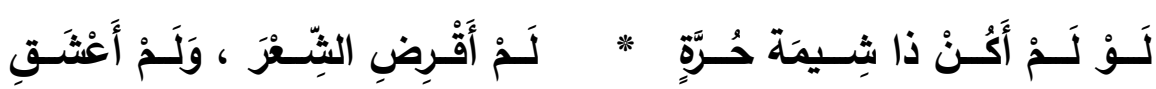

فالثعر - في نظره- كالحب لا يملك مقاده إلا أرباب الخصال النبيلة ممن

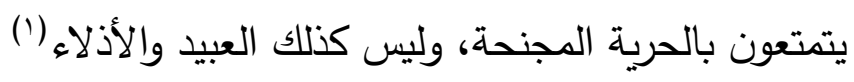

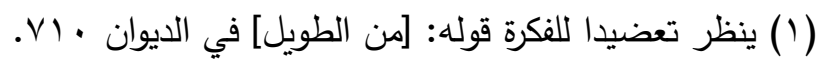

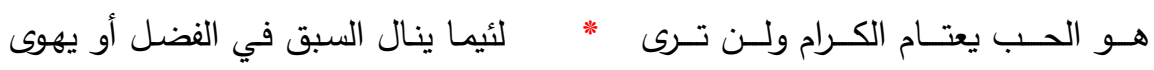

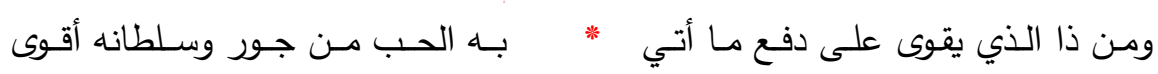

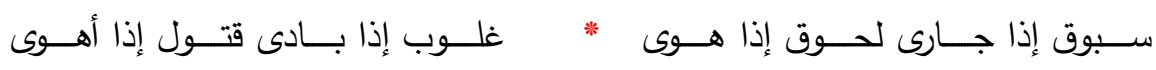




\section{الهبــذ الرابـر: أوصاف "الشنعر " القصبدة:}

إن من يتصفح ديوان البارودي يدرك أنه وصف قصائده بأكثر من وصف،

فنراه يصفها بالكواكب، كما في قوله: [من الكامل](')

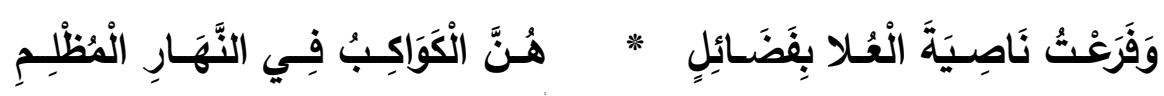

ولا شك أن هذا الوصف يضفي على شعره طابع الإشراق والإضاءة والتوهج والإيحاء بأن قصائده تتألق في أفق الفن والأدب تألق الكواكب المضيئة اللامعة في السماء، وأنها قادرة على جذب الأبصار وامتلاك الإعجاب. ومن تلك الأوصاف أيضا وصف قصائده بالحجارة الكريمة والجواهر واللؤلؤ والدر والياقوت، ألا تراه وصف "الثعر" القصيدة بالدر، على سبيل الاستعارة

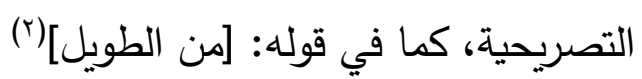

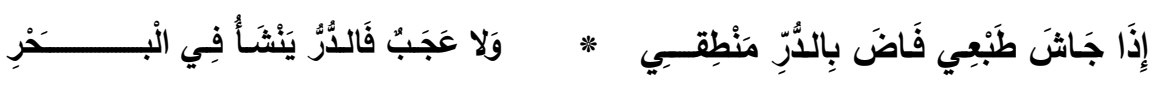
فاللفظ يحمل معنى رمزيا يرتد إلى معنى التفرد والتميز والندرة والنفاسة، وكأنه في الوقت نفسه وصف للشاعر نفسه بأنه غواص ماهر يحسن

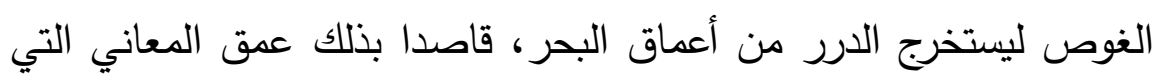
تتضمنها قصائده، وحسن اختياره لقصائده التي تأتي بعد التأني الثديد في النظم، وقد يحتمل قول البارودي "فالدر ينشأ في البحر" تشبيه البارودي بالبحر إن كان في الكلمة تورية تقصد معنيين قريبا يعود على البحر 
الحقيقي، وبعيدا يعود على الشاعر نفسه، إذا أراد من ذلك الإشارة إلى تعدد مواهبه.

وقريب من ذلك تثبيه الكلام عموما- شعرا كان أو نثرا- بالجوهر ، كما في قوله:

(من الطويل][ (')

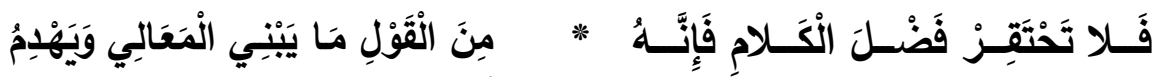

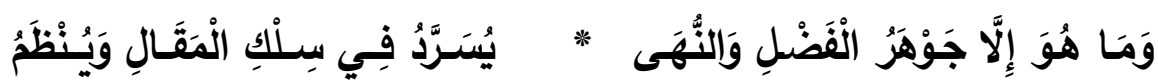
ومن ذلك وصف شعره باللؤلؤ، كما في قوله: [من الطويل](r)

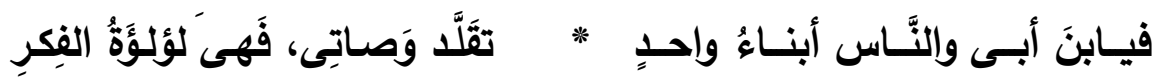
وقوله: [من السريع](ז) (

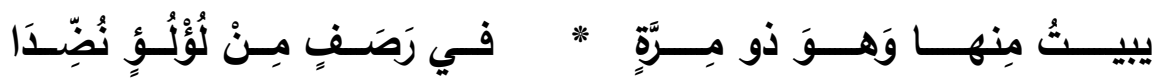
وواضتح أن وجه الثبه بين الشعر واللؤلؤ يكمن في القيمة العالية لكل منهما، كما لا يخفى ما في هذه التشبيهات من الإشارة إلى بقاء الشعر وخلوده بقاء هذه اللآلى

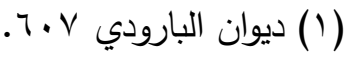

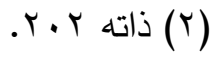

$$
\begin{aligned}
& \text { (r) ذاته }
\end{aligned}
$$


وقد يجمع بين اللآلى والأزهار في آن معا، فيقول: [من الطويل](')

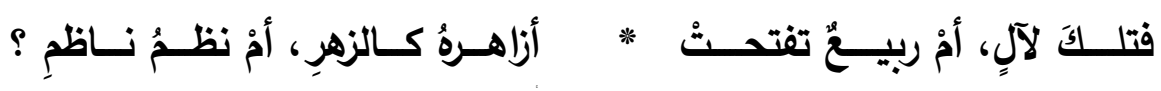
ووجـود الزهـر دلامـة على جمـال المنظر وطيب الرائحسة وانتشـارها، ليثـعر المتلقي بالابتهاج والنشوة.

كما يشبه شعره في القصيدة نفسها بالعقد الثين ليخلع على شعره مزيدا من

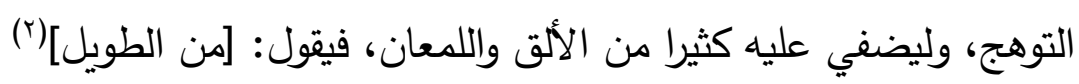

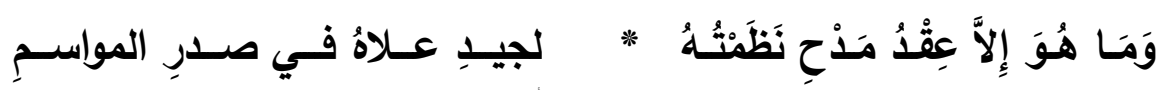
وأحيانا يفرد جزءا من القصيدة- وغالبا في الخاتمة- ليصف لنا القصيدة لديه بعدة أوصاف، كما في قوله: [من البسيط](ب)

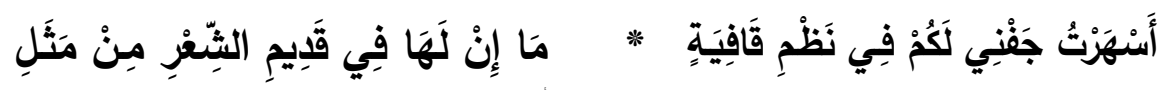
كالبرق في عجل والرعد في زجل * الغيث في هلل والسيل في همل غراء تعلقها الأسماع من طرب * وتسـتطير بهـا الألبـاب مـن جـل حوليـة صـاغها فكـر أقـر لـه * بـالمعجزات قبيـلـل الإنسس والخبـل

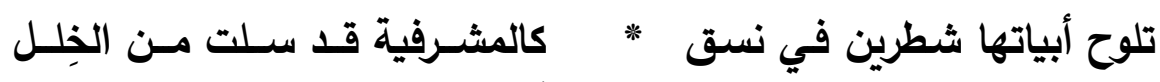

$$
\begin{aligned}
& \text { (1) ذاته ابro. } \\
& \text { (r) ذاته آبه (r) } \\
& \text { (r) ديوان البارودي ؟ (اء وما يليها. }
\end{aligned}
$$


إن أخلقت جدة الأثسعار أثلها لفظظ أصسيل ومعنس غيـر منتحل

تفنى النفوس وتبقى وهي ناضرة على الـهور بقـاء السبعة الطول

فخاتمة القصيدة هنا تحمل وصفا متعددا للقصيدة التي عبر عنها البارودي

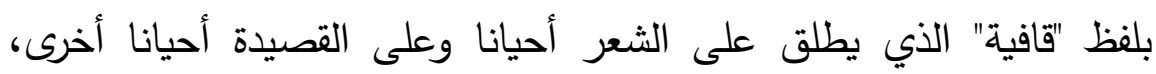
فيشبهها بالبرق في سرعته، وهذا لا يستبعد ضوءه، فالقصيدة تسرع إلى الى القيان العقول سرعة البرق وتضيء إضاءته، وهي أيضا كالرعد في دويه، أي أنها

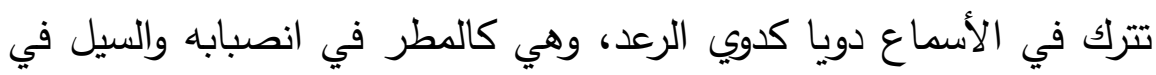

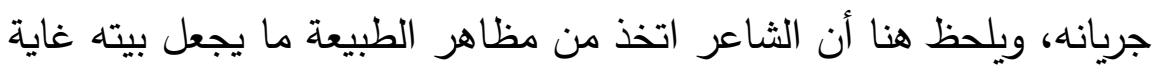

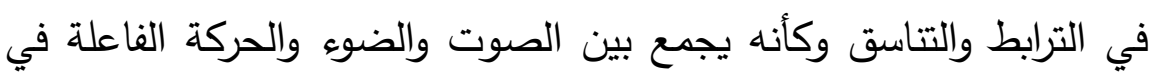

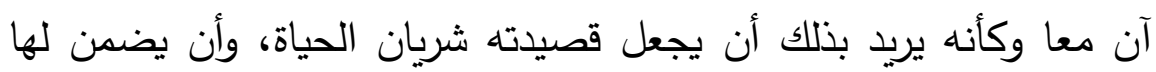

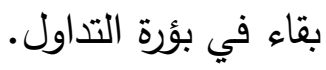

ووصف القصيدة هنا أو تثبيهها بالبرق يرتد إلى تثبيهها لاى البارودي

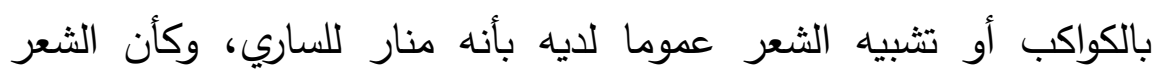

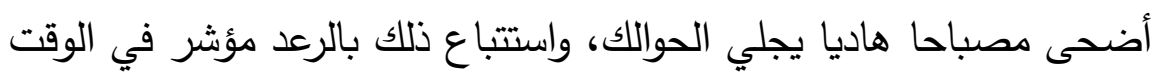
ذاته بالخير الممرع، ومبشر بالغيث الذي به يتحقق الخصب والنماء وقهر التها

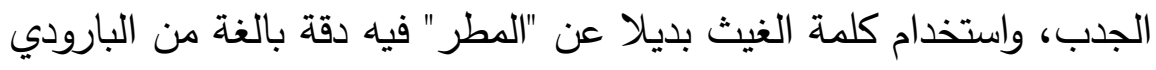

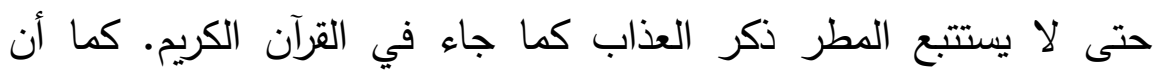

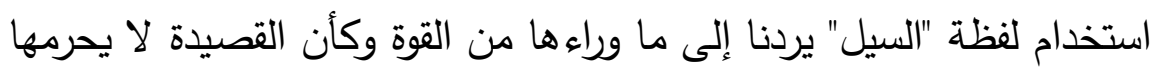

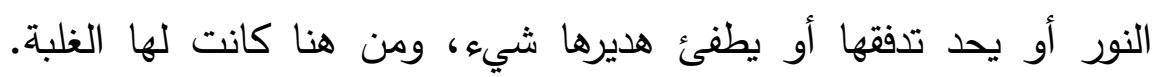

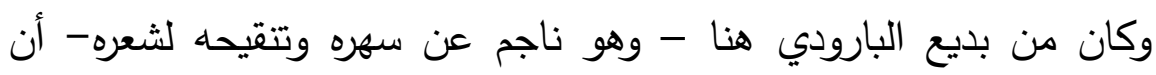

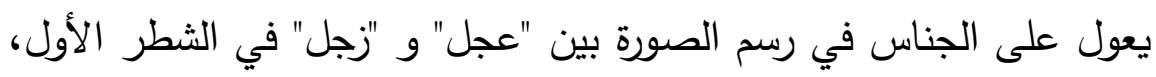


ثم بين "هل" و "همل" في الشطر الثاني، ولا يخفى كذلك ما في البيت من "تشطير" (') (1)

وفي البيت الثالث يصف القصيدة بأنها "غراء" أي مشهورة وواضحة، وهذا معنى مراد، لكنه في الوقت نفسه قد يرتد إلى وصف الأبيات الثعرية قديما

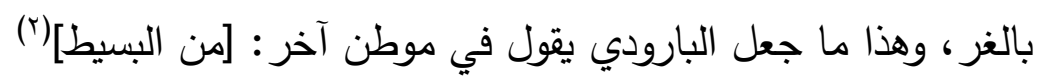

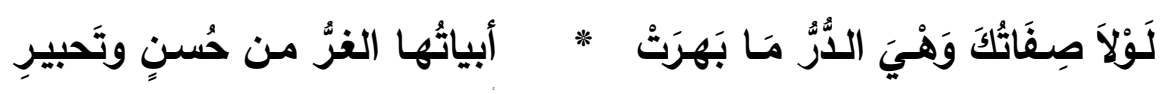
وقد جعل "ثعلب" هذه الأبيات "الغر" في الطبقة الثانية من تصنيفه للأبيات

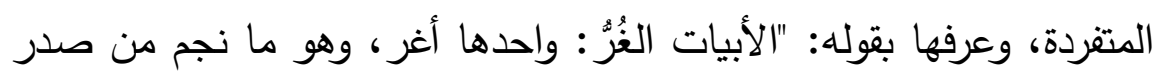
البيت بتمام معناه، دون عجزه، وكان لو طرح آخره لأغنى أوله بوضوح

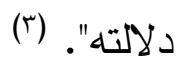

ومن ثم فالغر هي الأبيات التي تثتمل أوائلها على الكلام الموجز المستغني بنفسه عن سائر البيت بما فيه من اللمحة الدالة الموحية.

وقد سُمِّيَ البيت الذي تتحقق فيـه صنعة البيت الأغر بأسماء أخرى عند لفيف من النقاد والبلاغيين تعاقبوا بعد "ثعلب" كابن المعتز وقدامة بن جعفر لاءري

(1) هو أن يتوازن المصراعان والجزآن، وتتعادل أقسامهما مع قيام كل واحد منهما

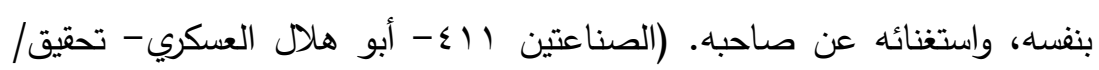
علي محمد البجاوي ومحمد أبو الفضل إبراهيم- المكتبة العنصرية - بيروت هنائه (ه) 19

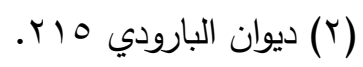

(r) قواعد الثعر VY - VY أبو العباس المعروف بثعلب - تحقيق د/ رمضان عبد التواب-

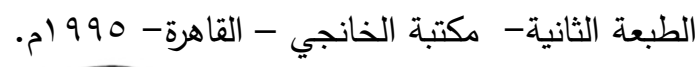


وأبي هلال العسكري وابن رشيق القيرواني ومن جاء بعدهم من المتأخرين،

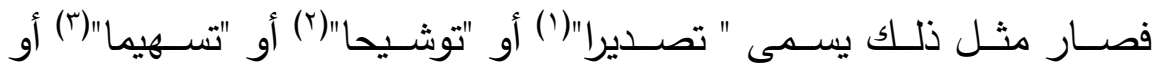
"ترديدا"(£" ( )

وفي بيت البارودي تصوير لمدى تأثير قصيدته في الأسماع والعقول معا، حيث تطرب السمع وترهفه لما بها من موسيقية بالغة، وتستظهرها العقول فرحا وحبا، ولعلك تلحظ مدى دقة البارودي في اختيار الكلمات الموزونة صرفيا، مثل: (الأسماع- الألباب) و (طرب- جذل) ليحقق بذلك نغما صوتيا لا جور فيه ولا شطط، وحتي يحقق التطريب والطيران لدى المتلقي.

(1) ينظر : البديع VV - ابن المعتز - اعتنى بنشره وتعليق المقدمة والفهارس/ إغناطيوس

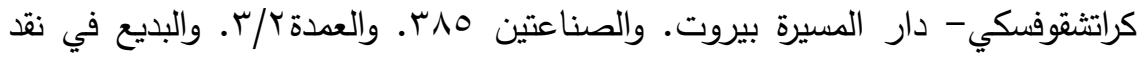

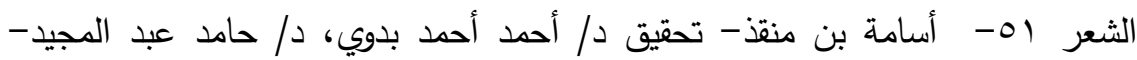

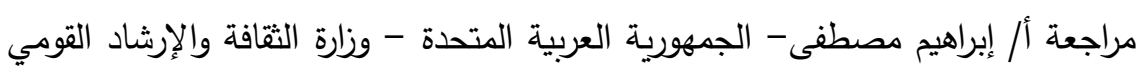
- الإقليم الجنوبي - الإدارة العامة للثقافة.

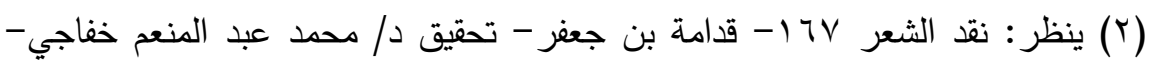

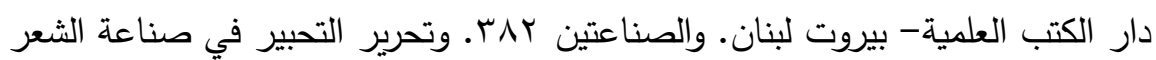

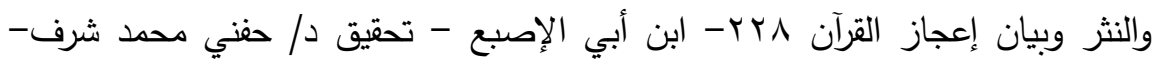
الجمهورية العربية المتحدة - المجلس الأعلى للشئون الإسلامية - لجنة إحياء التحرئ التراث الإسلامي.

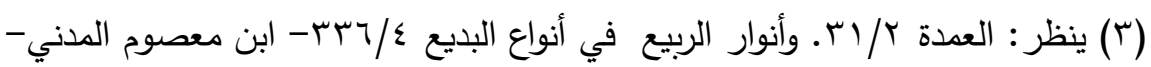

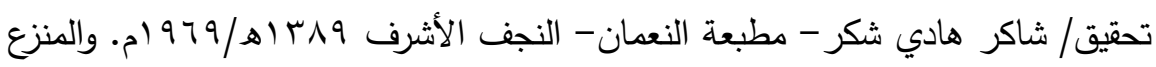

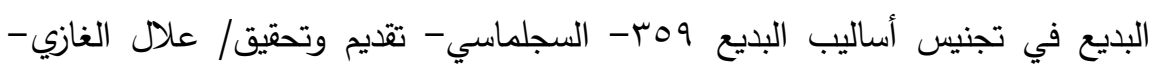

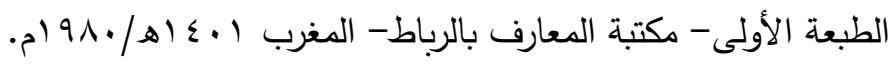

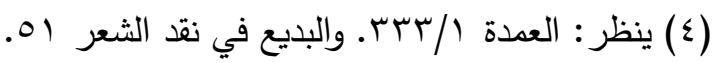


وفي البيت الرابع يصف قصيدته بأنها حولية، نسبة إلى الحول، وهو بهذا يحدد مذهبه في نظم الشعر، ذلك المذهب الذي يرده إلى أصحاب الصنعة - كما ذكرت- من أمثال أوس بن حجر وزهير بن أبي سلمى، وابنه كعب، والحطيئة وغيرهم من عبيد الشعر الذين كان يضنيهم عمل الشعر حتى تخرج القصيدة في ثوب بهي، خالية من المآخذ والمطاعن. ثم يصف في البيت الخامس قصيدته بالتناسق والتوافق، إذ يشتمل كل بيت منها على شطرين متسقين على نظام واحد، وهي في حالتها هذه كالسيوف المجردة من أغمادها تبهرك بلألائها وبديع نظامها وحسن تتسيقها، وكأن وأن وهين البارودي في ذلك الوصف يريد أن يخبرنا عن تركيب القصيدة وبنيتها الخارجية بأنها تراثية لحمة وسدى من ناحية ، ومن ناحية أخرى بأنه رجل محافظ متشبث بالشعر العمودي الخليلي لا يريم عنه، إيمانا منه أن ذلك لك النمط أجذب للقارئ وأوفر إيقاعا وموسيقية، وأبقى في الذاكرة من الثعر لئر

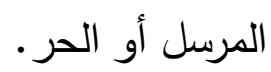

يقول د/ مدحت الجيار: "فهي من حيث النسق العام تتركب كالقصيدة القديمة من أبيات منسقة متسلسلة، وينقسم شطرين كل بيت على حدة، وتعتني باللفظ الأصيل الذي لا يتبع الغربب والمنقول إلا قليلا، بالطبع فهناك ألفاظ أعجمية كثيرة في هذه القصائد جاءت بسبب تسمية الأشياء بأسمائها عند أصحابها، أو كما تستخدم في الحياة اليومية المصرية، كذلك تعتني القصائد على لسان البارودي بالمعنى غير المنحل من الآخرين، بل تمتد الأصالة من اللفظ إلى المعنى" (1)

(1) الثعر العربي الحديث في القرن التاسع عشر - نظرة تاريخية نقدية 0؟ ؟. 
وفي البيت السادس يصف القصيدة بصفات هي من صميم الفن، حيث حبك النسج ومتانة التراكيب، والمعاني المبتكرة غير المسبوقة، فإذا بليت أشعار غيره من الشعراء وذهب ماؤها وتصوحت زهرتها فإن قصيدته باقية خالدة لمعانيها المبتكرة. وكان البارودي هنا من الحصافة بمكان حين افتخر بأن

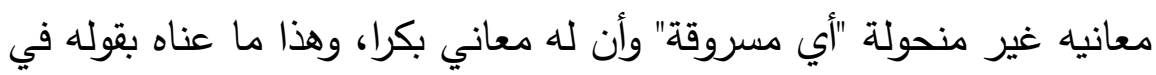

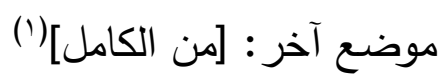

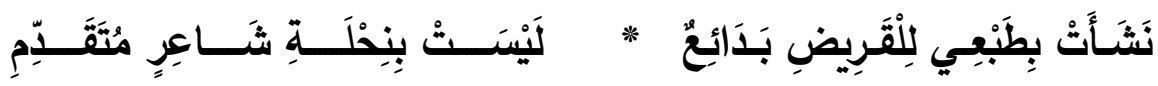
والبدائع جمع بديعة، مؤنث بديع، وهو المبتدع المخترع، وهو ما أشـار إليه البارودي في موضع آخر في قوله: [من الطويل] (ז)

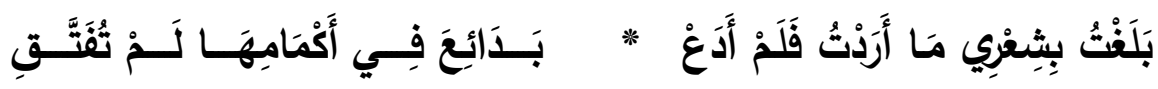
وكأن البارودي أن يعبر عن تسويخ موقفه من النسخ أو التكرار، إذ لا يقر استخدام المعنى المستهلك أو المتداول الذي لاكه كثير من الثعراء السابقين أو المعاصرين، دون أن يكون ثمة إضافة جديدة، فهو يتبنى التحويل والتوليد ونمو المعنى الذي ظهر من قبل نموا متكاثرا بتعديله ومنحه سمة عبقريته الشخصية.

وتأكيد البارودي على جدة قصائده وما تسخو به من إبداع وتقرد وأنها غير منتحلة تأكيد في الوقت نفسه لإثبات ذاته وقدرته على منافسة كبار الشعراء،

$$
\begin{aligned}
& \text { (1) ديوان البارودي ONV . } \\
& \text { (Y) ذاته ارب وما يليها. }
\end{aligned}
$$




\section{العدد الحادي و الثلاثون}

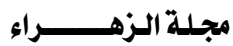

هذا إلى جانب ما يصم السارق بعيوب تجعله في المرتبة الدون، وصدق طرفة بن العبد حين قال:[من البسيط](')

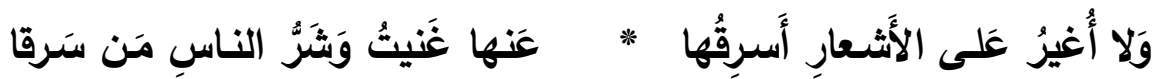

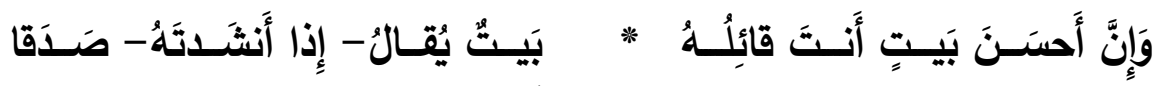
ولعل ربط عدم الانتحال بالصدق في قول طرفة يعزز هنا رؤية البارودي في هذا الجانب، وهو عدم سرقة الأشعار والسطو عليها، وإلا ففيم نفسر استشهاده في مقدمة الديوان بالبيت الثاني من أبيات طرفة ناسبا إياه لأبي

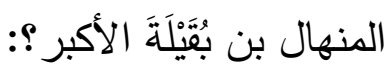

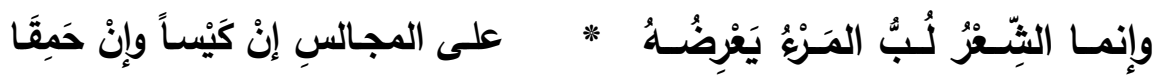

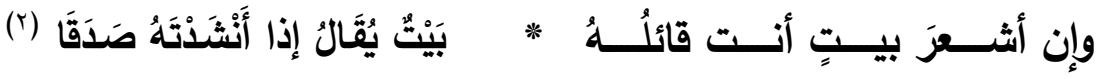
ألا يـل ذلك على أن من الصـدق أن لا يسطو الثـاعر على معـاني

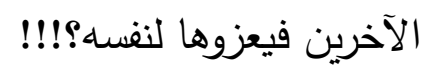
وفي البيت الأخير يشير إلى بقاء قصائده وخلودها، وقد تحدثا عن ذلك مما أراني في غنى عن تكراره.

(1) ديوان طرفة بن العبد بشرح الأعلم الثنتمري ع V ا - تحقيق/ درية الخطيب ولطفي

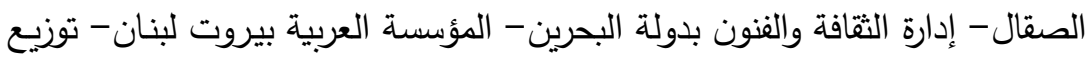

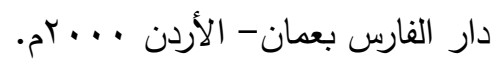
(r) ديوان البارودي (المقدمة) هب وما يليها. 
ومن الأوصاف التي خلعها البارودي كذلك على شعره أو قصائده والتي لها صلة بصفة عدم انتحال شعر الآخرين، صفة "الحبيرة" وهي الثياب الجديدة الموشاة الناعمة، ومن ذلك قوله مادحا شكيب أرسلان: [من الطويل](')

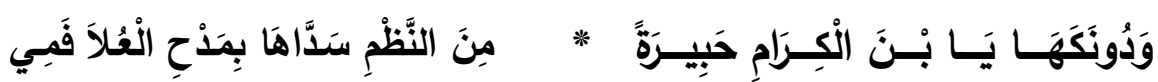
وقوله في الخديوي إسماعيل: [من الكامل](؟)

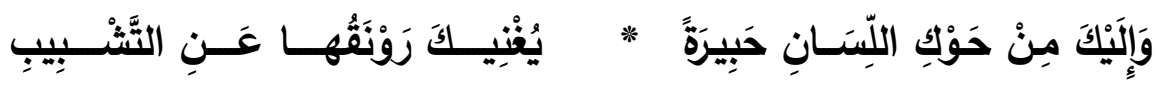
وأرى في تشبيه الثعر بالثياب الجديدة إشارة من البارودي إلى جدة قصائده فلم تكن قصائده جارية على سنن واحد لا تريم عنه، بل هو في كل قصيدة يلبس لبوسا معينا ذا نكهة متباينة هذا إلى ما أكاد ألحظه في الجذر اللغوي للكلمة نفسها "حبر" من إيحاء بمعنى التجويد والتهذيب والتشذيب الذي يرتد إلى عملية الصنعة الثعرية لديه، وهذا ما يؤكده قوله في القصيدة التي منها البيت السابق يمدح شكيب أرسلان: [من الكامل](؟)

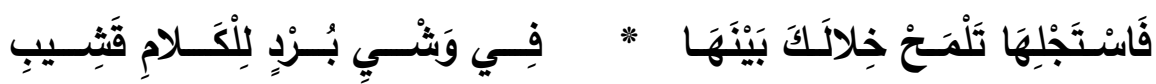
فجمع بين الوشي وهو الترقيم والتنميق، والقشيب الذي يعنى الجدة.

$$
\begin{aligned}
& \text { (1) ديوان البارودي ؛ ذاته } \\
& \text { (r) ذاته rז } \\
& \text { (ז) ذاته }
\end{aligned}
$$


وهذا ما أراده بكلمة الوشي أيضا حينما مدح شعر البحتري بقوله: [من البن

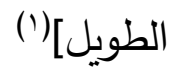

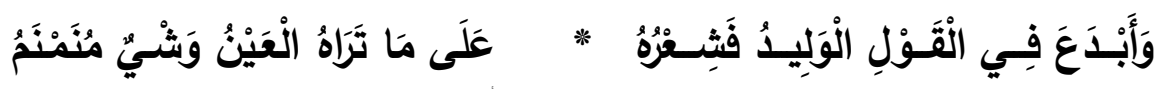
بما في الكلمة من تزيين وزخرفة.

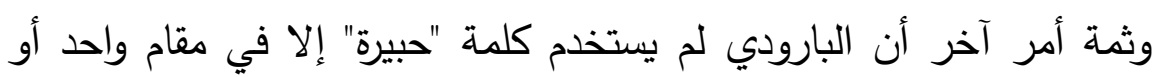

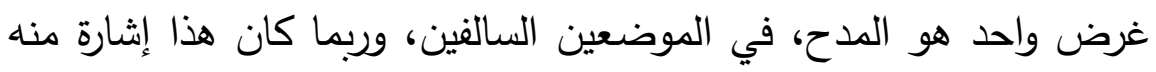

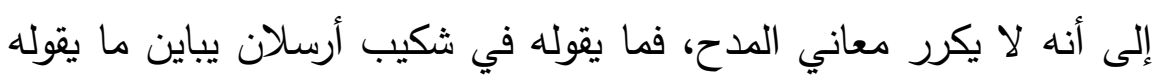

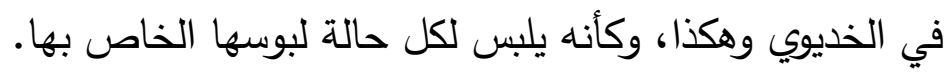
والبارودي لا يني يشير إلى أن الثعر تسدية "سداها بمدح العلا فمي" وحياكة "من حوك اللسان" ويشير في موضع آخر أنه نسيج، كما في قوله:

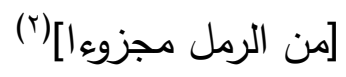

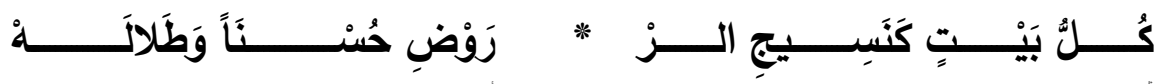
فهو يشبه كل بيت من شعره بالروض النضير المزهر المبهج، لما بينهما من

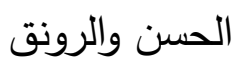

ولا شك أن التسدية والحياكة والنسيج كلها تتعلق بالثوب، وكأنه يريد بذلك أن

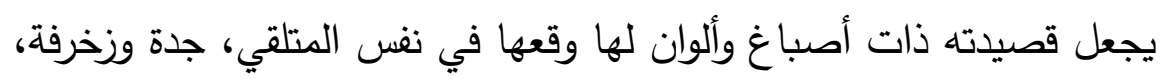
بما تحمل من مفاتن الإغراء والأخذ بالألباب "يغنيك رونقها عن التشبيب".

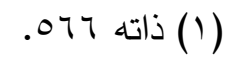

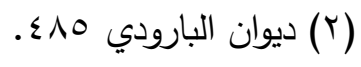


ومن ثم أكاد أجزم أن البارودي وإن لم يصف قصائده بالبكارة كما فعل غيره من السابقين، فقد كان في وصف قصائده بالبدائع وأنها ليست بنحلة شاعر متقدم، وأنها حبيرة، ما فيه الكفاء والغناء الذي يبرز تلك البكارة. لا سيما وأن البكارة قد تكون إضافة جديدة، أو توليدا لمعنى ظهر من قبل (') . ونـراه في مواضـع متعددة من شعره يجمع بين شعره والسـر ، فيقول: [من

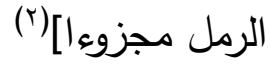
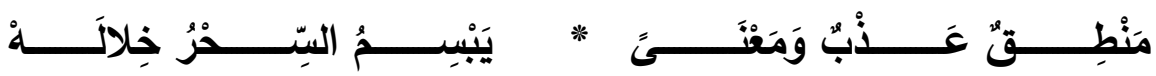

فالبيت هنا قائم على الكناية عن بهاء شعره وجماله وحسن روعته. ثم نراه في

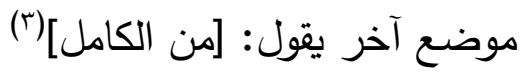

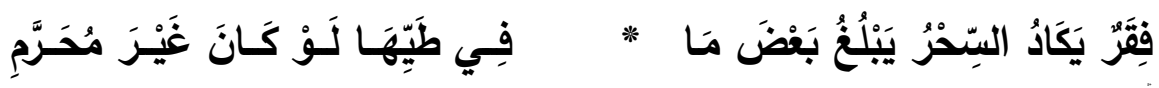
وثــة موضـع يفخر فيـه بصـوغ قصـائده مـن السـحر الحـلال، فيقول:[من (الطويل]

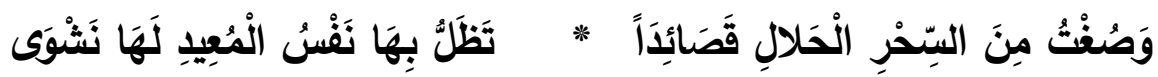

(1) للمزيد في موضوع قدرة البارودي على التوليد ينظر كتاب استعادة الماضي للدكتور

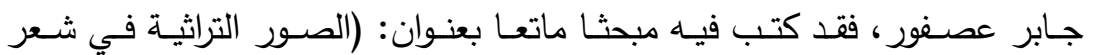

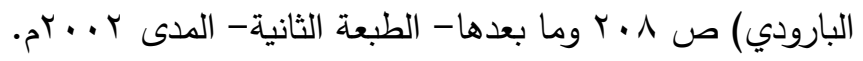

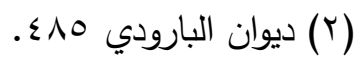

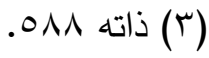
. \) ذاته 


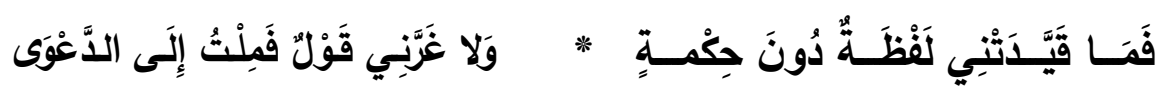

والسحر الحلال هنا هو البيان العالي الرائع، الذي يسكر كل من يسمعه من وجهة نظره، وإن كنت أرى أنه هنا متأثر بقول الرسول- صلى الهى الله عليه

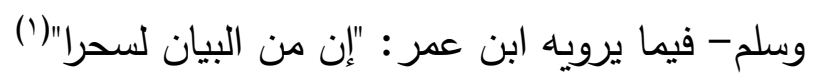

ولا شك أن الجمع بين الثعر والسحر ، أو تشبيه الثعر بالسحر يعود لعدة

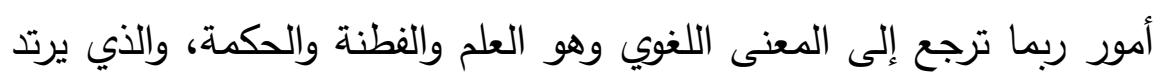

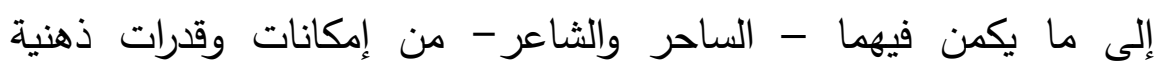
ووجدانية خاصة، وإلى الاستعداد الفطري والتميز عن الغير بموهبة أفضل

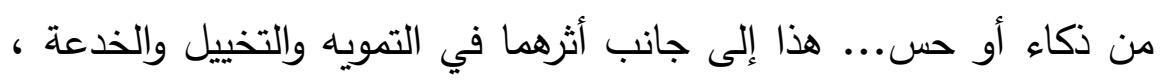

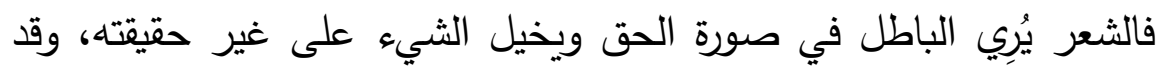
ذكر أبو عبيدة في معنى قوله صلى الله عليه وسلم: " إن من البيان لسحرا":

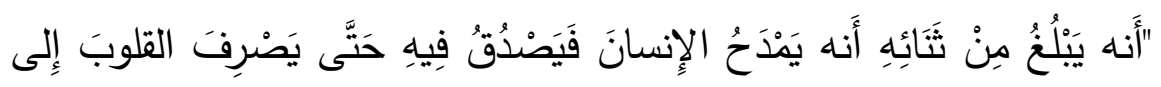

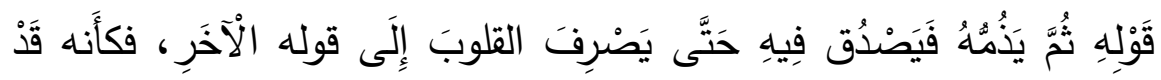

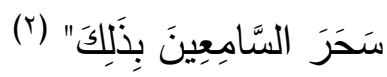

وإخال أن البلاغيين ربما اتخذوا من قول الرسول صلى الله عليه وسلم: إن لنيل

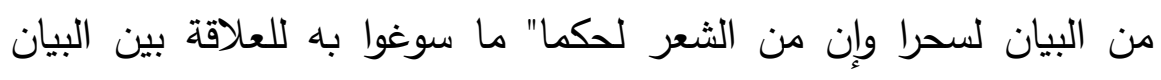

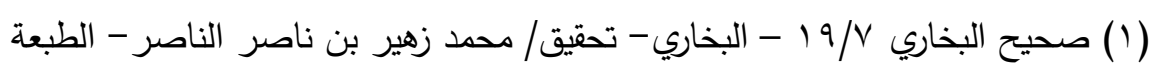

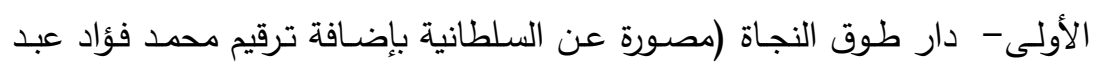

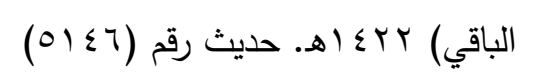

(ז) لسان العرب- مادة [س، ح، ر] ابن منظور - الطبعة الثالثة - دار صادر بيروت 
والسحر؛ "لأن السحر يخيل للإنسان ما لم يكن للطافته وحيلة صاحبه، وكذلك البيان يتصور فيه الحق بصورة الباطل، والباطل بصورة الحق؛ لرقة معناه، ولطف موقعه، وأبلغ البيانين عند العلماء الشعر بلا مدافعة، وقال رؤبة:

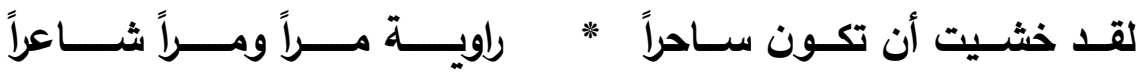

فقرن الشعر أيضاً بالسحر لتلك العلة"(1) وقالوا في تعريف الاستعارة - وهي من أهم خصائص الثعر - إنها: "نقل العبارة عن موضع استعمالها في أصل اللغة إلى غيره لغرض"(ז) وهو هور تعريف يلتقي تماما مع تعريف "السحر" في لسان العرب: "قَالَ الأَزهري:

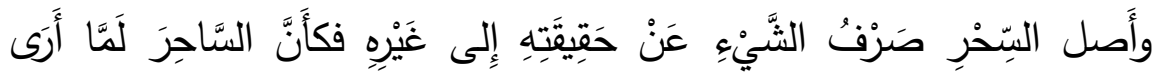

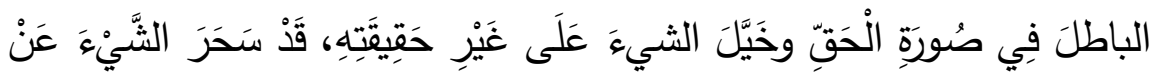
وَجْهِهِهِ أَي صَرَفَفُهُ"

ومن ثم تصبح لغة الثعر ولغة السحر مجازية رامزة، لأن ثمة عدولا أو انزياحا عن سنن الكلام العادي تحيله إلى شيء من الإربالك في العلاقة لدى المتلقي، ومن ثم يكون التأثير الناجم من ذلك. "وبهذا يكتسب كلام الشعراء

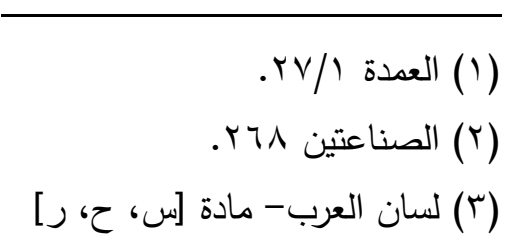


والسحرة صفة الكثافة التعبيرية، وكثافته هذه تجعله يتفوق على الكلام العادي

في القدرة على رصد كثافة العواطف والظواهر والأثياء وتسجيلها"(() ألا ترى البارودي في قوله متغزلا : [من البسيط](؟)

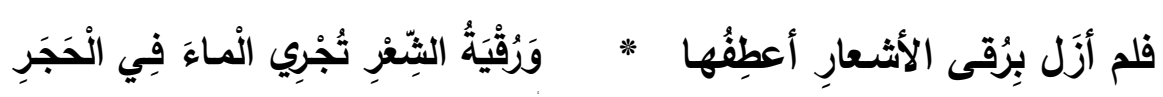
يثير إلى أن لغة الثعر تفعل ما يفعله السحر، وأنها تمارس نفوذها وسلطتها في تغير المألوف وقلب الأمور ·

وأظـن أن هـذا مـا كـان يعنيـهـ أبـو نـواس مـن قبـل حين قـال متغـزلا: [من (الطويل[ن)

فمـا زلت بالأثسعار من كل جانب * ألينهـا والثـعر مسن عقــ الســر

ومن ثم فالبارودي كان قارا في نفسه أن التخييل والحدس التخييلي هو رؤية للغيب أو قوة رؤياوية تستشف ما وراء الواقع، ولم لا؟ وكان يشعر بأنه يتتزل منزلة أعلى من البشر، كمنزلة الأصفياء والأببياء، وكأن النداء يأتيه بالتبصر من وراء الغيب، وأنه حكيم يرى أبعد مما يراه المبصرون، كأنه في

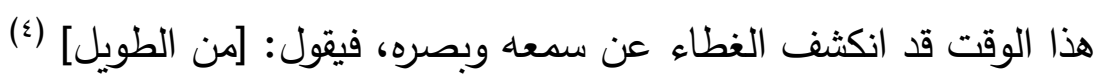

(1) في صلة الشعر بالسحر • V- د مبروك المناعي- بحث منشور بحولية كلية الآداب

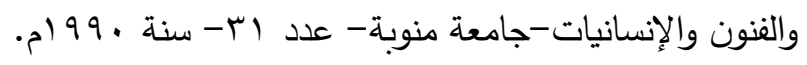

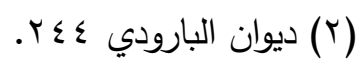

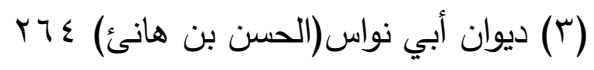

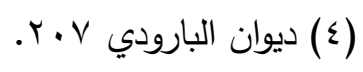




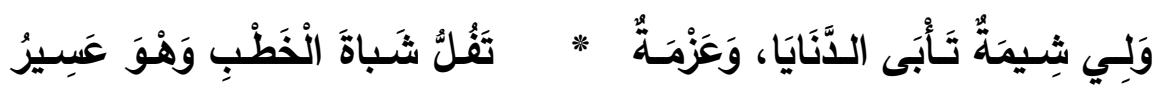

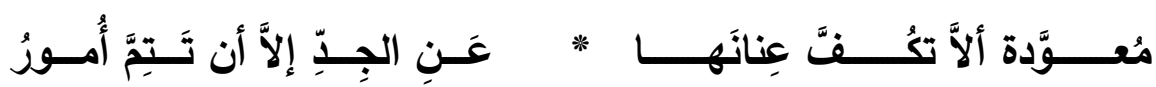
لها مسن وراء الغيب أذن سـميعة * وعين تـرى مــا لا يـراه بصسير ولا يني يردد هذا المعنى في وصف أستاذه "المرصفي" قائلا: [من ('الطويل]

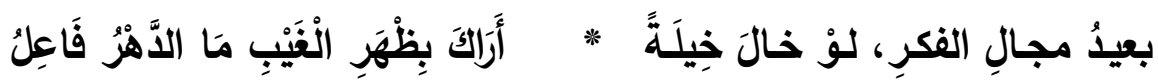
ويردده مرة أخرى في مدح الخديوي إسماعيل، قائلا: [من الطويل](†) لـهُ تحسَّ أستارِ الغيوبِ، وَفوقها * عيونُ ترى الأثشياءَ، لا وهم واهمِ وماذا نفهم قوله في شكيب أرسلان: [من الكامل](")

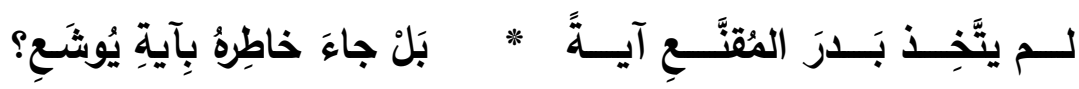
إلا أن الثعر صار معزة للشاعر، استطاع من خلالها تجاوز حركة

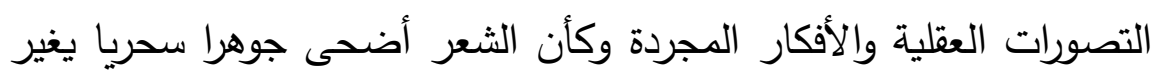

$$
\begin{aligned}
& \text { (1) ديوان البارودي هبع. } \\
& \text { (r) ذاته 0ror. } \\
& \text { (ץ) ذاته عس". }
\end{aligned}
$$


معادلات الزمان والمكان ويغير نواميس الحياة وينسخ قوانين الطبيعة. ألم يقل البارودي في وصف قصيدته: [من البسيط]'(')

حوليـة صـــاغها فكـر أقـر لـه * بـالمعجزات قبيـلـل الإنسس والخبـل

وكيف نفهم قوله واصفا قصيدته: [من الطويل](؟)

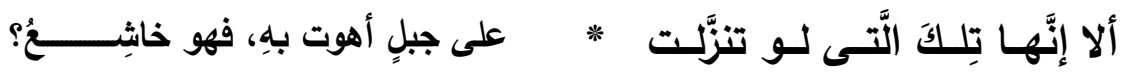

ألا يـدل ذلـك كلـه على أن للثـعر لـدى البـارودي طابعـا يتجـاوز حـدود التصـورات العقلية أو تجاوز مـا هو ممكن.... إذ كيف لقصـائده إذا هوت

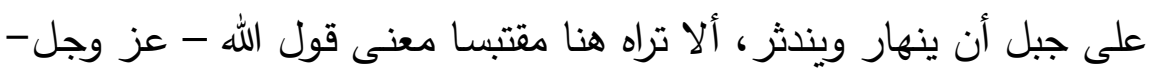

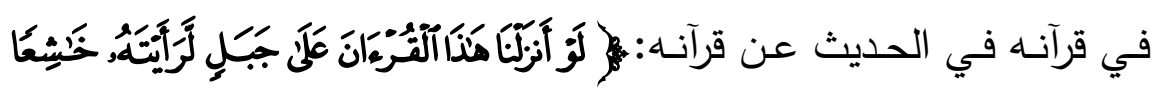

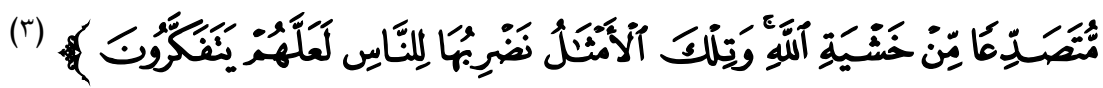
والحق أنني لـ أجد من النقاد القدامى مثل الإمام عبد القاهر الجرجاني أقدر على النفاذ إلى صميم العملية الشعرية، متجاوزا بذلك السطح والقشرة ليجعل الشعر يعمل عمل السحر، وذلك في قوله: "وهل تشكُُّ في أنه يعمل عمل السحر في تأليف المتباينين حتى يختصر لك بُعْدَ ما بين المشرق والمغرب،

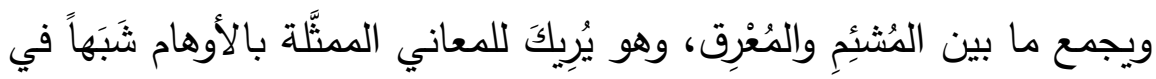
الأشخاص الماثلة، والأشباح القائمة، ويُنطق لك الأخرس، ويُعطيك البيان

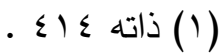

$$
\begin{aligned}
& \text { (r) ذاته } 9 \text { ) } \\
& \text { (ب) سورة الحشر: آية آب. }
\end{aligned}
$$


من الأعجم، ويُريك الحياةً في الجماد، ويريك التئامَ عين الأضداد، فيأتيك

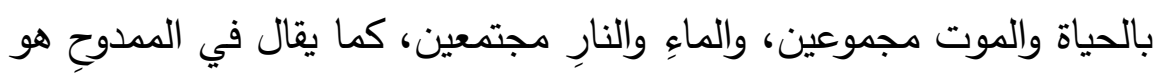

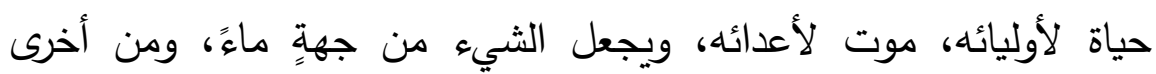

كما أنهما- أي السحر والثعر - في التصور العربي القديم يلتقيان "في منابع

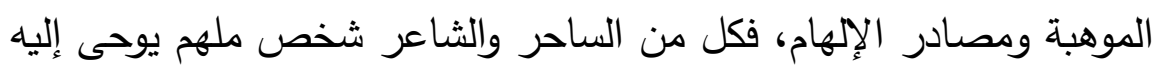

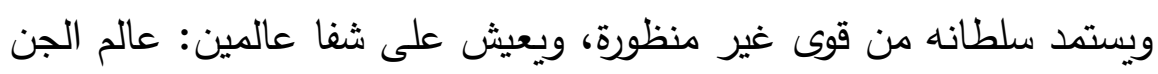
وعالم الإنس، عالم الغيب وعالم الثهادة، يشاركهما هذه المنزلة طرف ثالث الثان هو الكاهن. وبالرغم من الالتباس الكبير أحيانا بين هذه الأطراف الثلاثثة

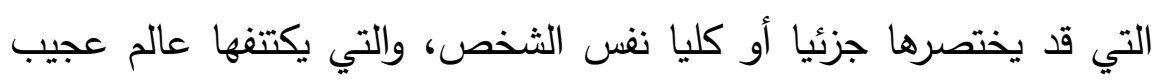

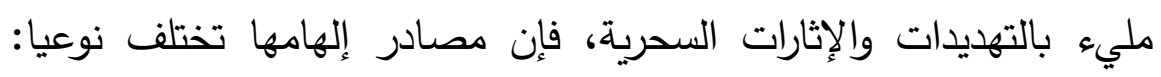
فملهم الساحر "جني" وملهم الشاعر "شيطان" وملهم الكاهن "رئي". ولكنها

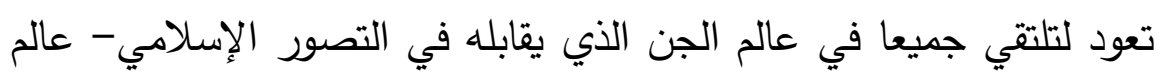
الملائكة. والمعروف أن الجن يتسمعون على السماء لالتقاط أسرار الله، وأن التهان

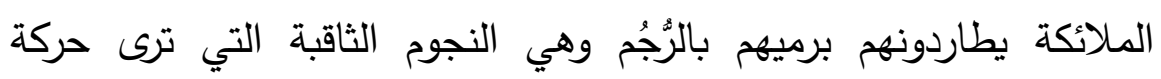

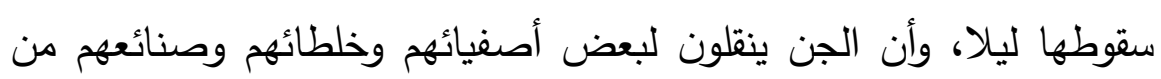

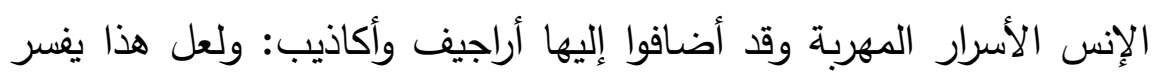

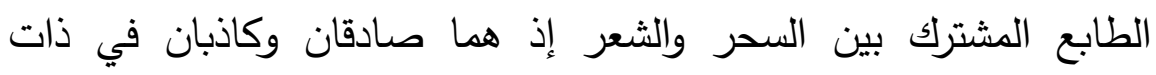

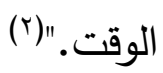

(1) أسرار البلاغة r إ - عبد القاهر الجرجاني-قرأه وعلق عليه: محمود محمد شاكر الناشر : مطبعة الدني بالقاهرة، دار المدني بجدة.

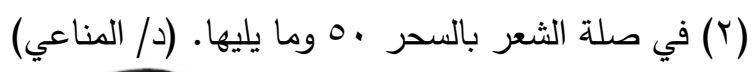


كذلك يلتقيان "فيما يسبق كليهما من استعداد وتهيؤ: فكما أثر عن السحرة لبسهم المسوح وتوضؤهم باللبن وظهورهم قبيل ممارسة عملهم بمظهر خاص، كذلك أثز عن الثعراء القدامى أن الثاعر منهم كان إذا أراد إلقاء شعره تهيأ لذلك واستعد له وأظهر للناس أنه يريد إلقاء شعر، ومن أصولهخ في الإلقاء أن ينشد الثاعر شعره وهو قائم أو مشرف أو يلبس الوشي والمفطعات والأردية السود وكل ثوب مشهر ... وقد استدل بعض المستشرقين من هذا الوصف على أن الثعراء إنما أخذوا تقليدهم هذا من السحرة أجداد الشعراء، ومن الكهنة لأن السحرة والكهنة كانوا ينظمون الثعر وينشدونه

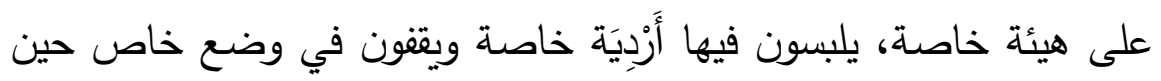

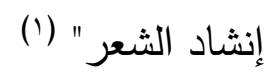

ولعل هذا يصدق فيما قاله البارودي نفسه عن شعره: [من الطويل](؟)

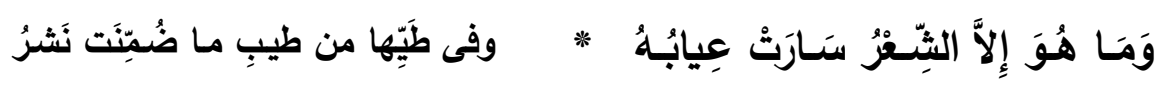

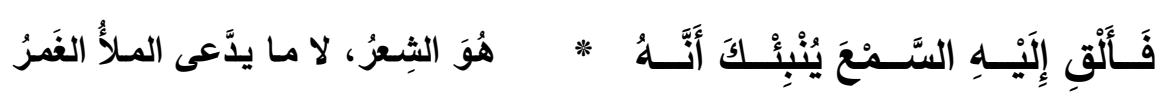

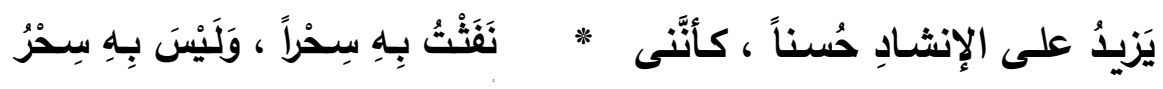
فالحسن الناجم عن كثرة الإنشاد يفعل بالألباب ما يفعله السحر، وإن كان ليس ثمة سحر حقيقي، فلإنشاد أثر "في إحداث الظواهر النفسية وتحرير الانفعالات وتحريك البواطن، فالغناء يسهل في احتفالية السحر والشعر الثر والاحتفالات الروحية عامة - انغراج العقد وزوال الحجب والكوابيس، ويطلق

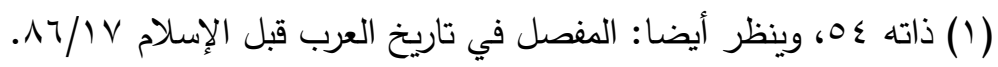

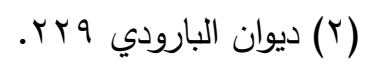


ما كبت... فالمشترك بين السحر والشعر هو الأثر العجيب الذي يمارسه

الخطاب الثفاهي المنغم والذي يسهم في جعل البيان سحرا"(')

ولا يخفى كذلك ما يجمع بينهما من جانب ترنيمي، فالوزن مشترك بينهما إلا أنه شعر عند الثاعر وسجع لاى الساحر وغيره. 


\section{المبــث الفامسر : وظيفة الشهر:}

لا شك أن للبارودي رؤية في وظيفة الثعر أفصح عنها من خلال بعض الأبيات التي بثها بين تضاعيف قصائده، وهي الوقت نفسه متساوقة ومتناغمة مع ما ضمنه مقدمته النقدية لايوانه، فهو حينما يقول: [من

(الطويل] (1)

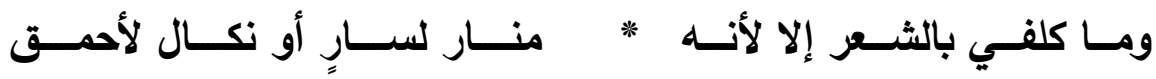

أو يقول: [من البسيط][)

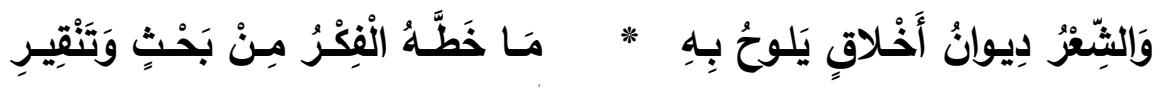

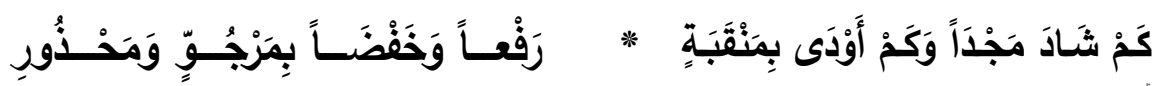

أو يقول: [من البسيط][)

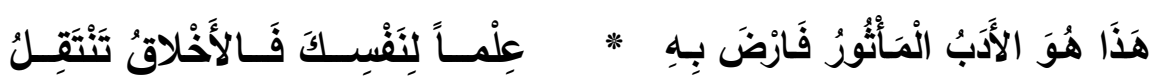

يضع بين أيدينا فكرة واضحة عن الوظيفة الاجتماعية للشعر لديه، إذ كان يؤمن أنها "تحدد في ضوء اعتبارين: أولهما أن الثعر وعاء يحفظ مفاخر العرب وفضائلهم الأخلاقية. وثانيهما أن للشعر قدرة خاصة على تعليم القراء

$$
\begin{aligned}
& \text { (1) ديوان البارودي ايمّ. } \\
& \text { (r) ذاته TVO } \\
& \text { (T) ذاته }
\end{aligned}
$$


القيم الخلقية الموروثة التي تدفعهم إلى العمل الصالح وتجنبهم العمل

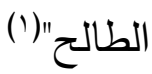

وهذا متتاغم ومتساوق مع ما نثره في مقدمة ديوانه إذ يقول: "ولو لم يكن من

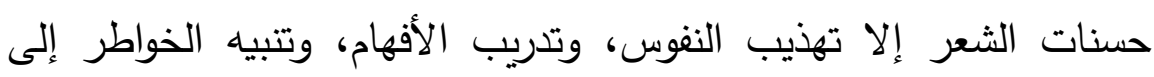

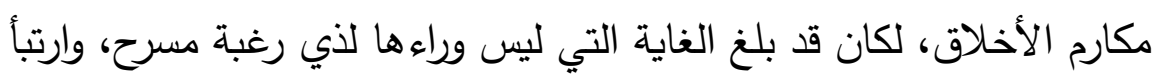

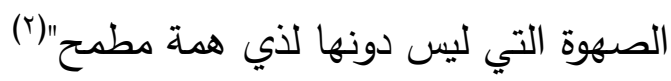
كما يتساوق ويتناغم مع ما ذكره نثرا عن الثعر ودوره في مقدمته ذاتها

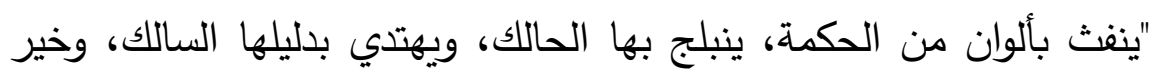

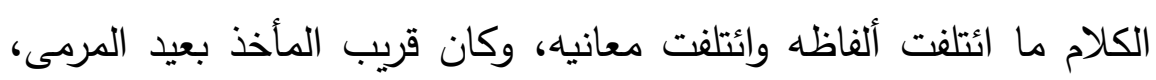

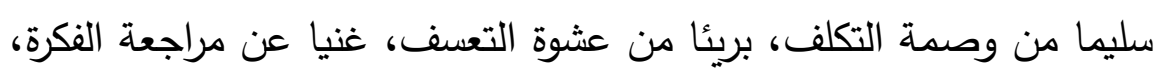

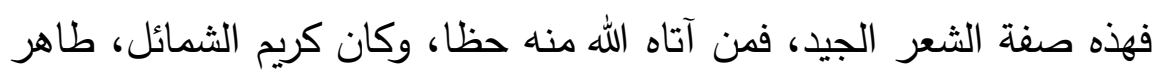

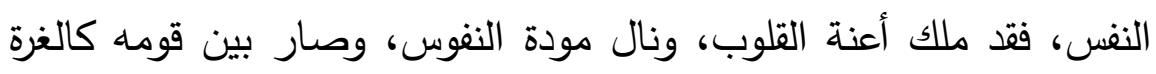

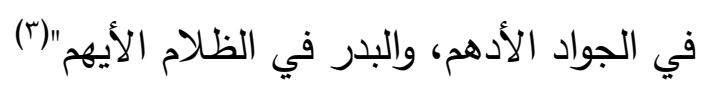

والحق أنني أرى الوظيفة الأخلاقية للشعر لاى البارودي مرتبطة بقضية

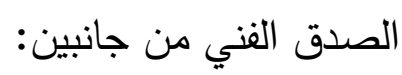

الأول من أن الصدق نقيض الكذب الأخلاقي، وفي هذا الجانب نرى

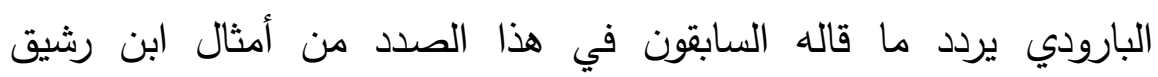
القيرواني الذي يقول: "وكان الكلام كله منثوراً فاحتاجت العرب إلى الى الغناء

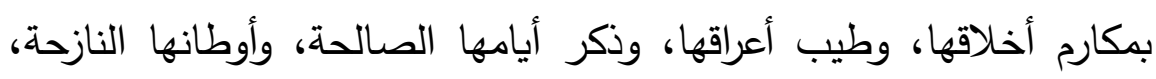

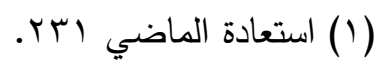

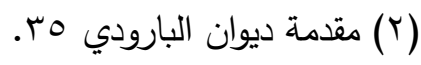

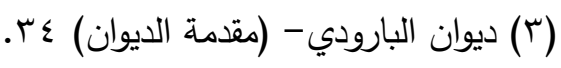


وفرسانها الأمجاد، وسمحائها الأجواد؛ لتهز أنفسها إلى الكرم، وتدل أبناءها على حسن الثيم فتوهموا أعاريض جعلوها موازين الكلام، فلما تم لهم وزنه سموه شعراً؛ لأنهم شعروا به، أي: فطنوا"(') . وتأكيدا على ذلك من ترديده لمقولات السابقين وإحيائها ما ذكره في مقدمة

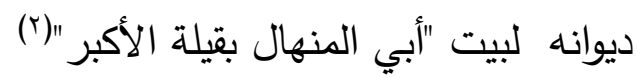

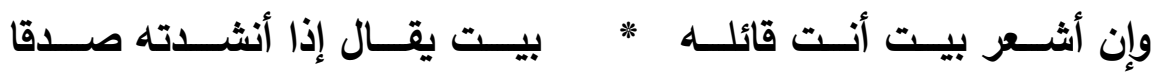
ولعل هذه الوظيفـة الأخلاقيـة هـي التي جعلت البـارودي ذا أنفـة لـم يتخذ الثعر وسيلة للارتزاق والتكسب ينادم به ذوي اليسار أو يتزلف به إلى من هن بيدهم الحل والعقد كالحكام والأمراء، وقد بين في مقدمته لديوانه أنـه يقول الثـعر "لا تذرعا إلى وجـه أنتويـه، ولا تطلعـا إلى غنم أحتويـه، وإنمـا هـي أغراض حركتتي، وإبـاء جمـح بـي، وغرام سـال على قلبي، فلم أتمالك أن أن

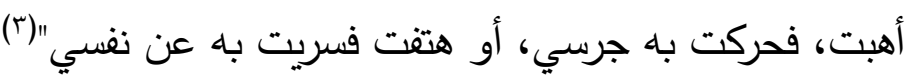
وعليـه فقد نـأى بنفسـه عن الترخص المقيت والتبذل المـرذول فارتفع بنفسـهـ وارتفع بـه شعره، في حين هوى بـه آخرون ولـوا وجوههم صسوب المركب

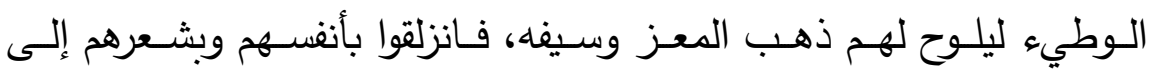

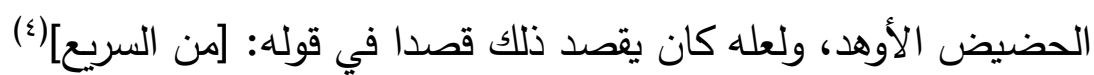




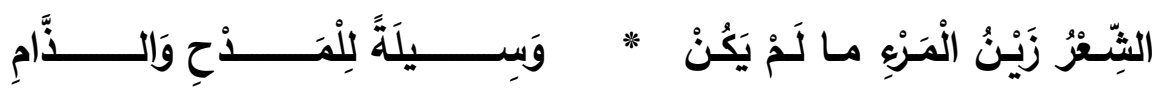

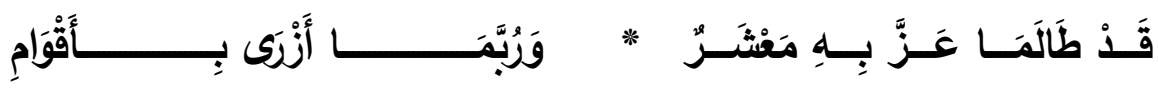

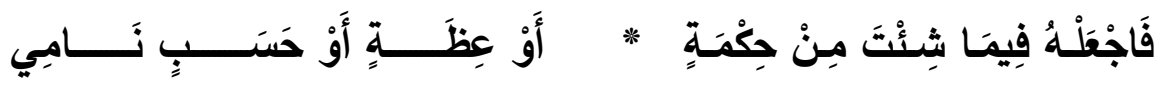

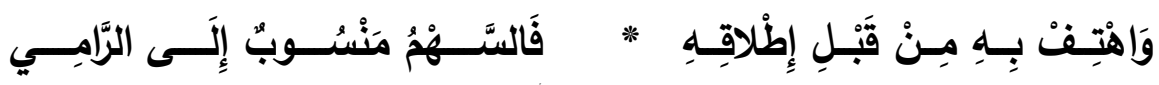
وكأنه متأثر في ذلك بالحديث النبوي الثريف الذي يرويه أُبَيٌُ بن كعب عن

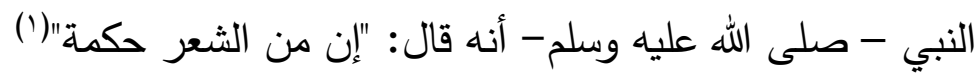
ولعل من ينظر إلى قوله: [من الخفيف](Y)

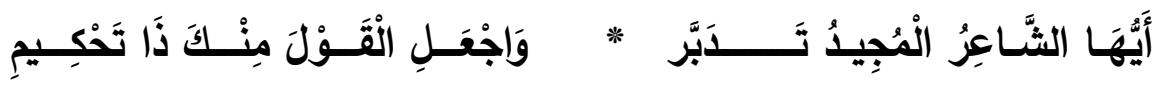

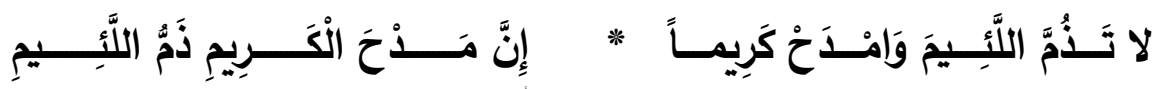
يدرك أنه يريد أن يعزز القيمة الأخلاقية في البعد عن السباب والفحش في القول، فهو ينهى عن ذم اللئيم، ويحث على مدح الكريم الذي يفهم منه النها لئه ضمنا أنه ذم لغير لكريم (اللئيم) لهون

أما الجانب الثاني فيتعلق بالصدق الفني الدتوافق مع التفاعلات الداخلية للذات المبدعة، والذي يعد ما لا يتوافق معها تكلفا ينتمي إلى الصنعة الرديئة

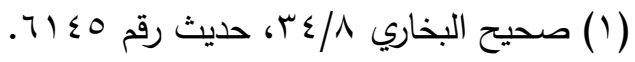

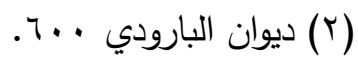


والحرفية الفقيرة، وفي هذا إشارة لوظيفة الشعر الجمالية، ولعل هذا ما عناه البارودي بقوله: [من الطويل](')

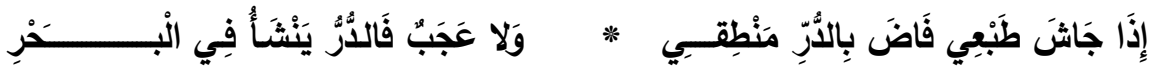

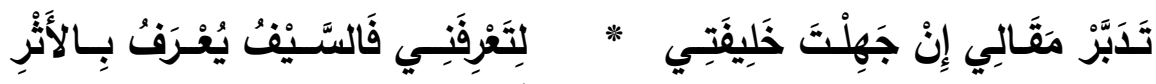
يقول د/ مدحت الجيار : "ويستخدم البارودي للتعبير عن (الطبع) فعلا مشتقا منه حيث نجد المخيلة تطبع، ليصبح الأمر (مصورا) مما يعود بنا ثانية إلى مي ولى علاقة الطبع (النفس) بالمخيلة (التخيل) والتصوير (الصورة) ولكن الصورة هنـاـ- وهـي نتاج الطبع والمخيلـة، هـي الصـورة الذهنيـة، وليســت الصـورة الثـعرية كمـا نجـدها الآن في النقـد المعاصـر ، وقـد تتطـرق هـذه الصـورة البارودية مع التخيل إلى الصورة البلاغية كما فهمها النقد العربي القديم، في محاولة منه لتحويل المجرد إلى ملموس ومحسوس، وفي غالب الأحيان إلى صورة بلاغية بصرية"(ب) ألا ترى البارودي يقول في حبيبه المقنع: [من الكامل](؟) ناديــت لمـا لاح تحـت قناعـه * هذا "المقــع" فاحذروا أن تسـحروا

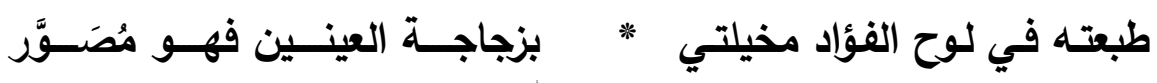

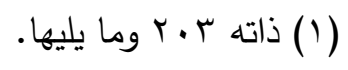

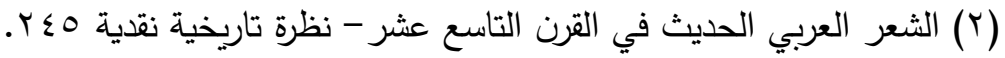

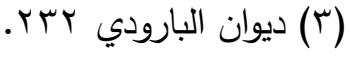


ويقول أيضا: [من الخفيف](')

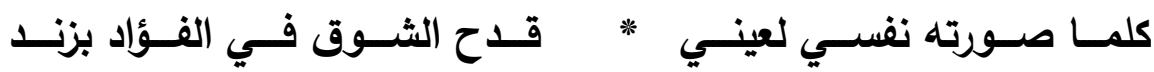
ويقول: [من الطويل][(r)

إذا اعتورتها ذُكرةُ النَّفسِ أبصَرَتَ لها صُورةً تختالُ فى صفحةِ الفكرِ "ويعني ذلك أن (الطبع/ ذكرة النفس) تجري عملية نفسية، بلاغية، عقلية

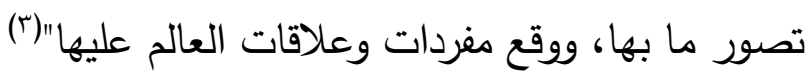
ويقول د/ جابر عصفور : "وإذا كانت القوة المتخيلة هي القوة التي تتوسط ما بين الحس والعقل فمن البديهي أن يكون عملها متصلا بهذين الجانبين، فتأخذ عن الحس معطياتها أو مادتها الخام، وتعيد تثكيلها أو التأليف بينها،

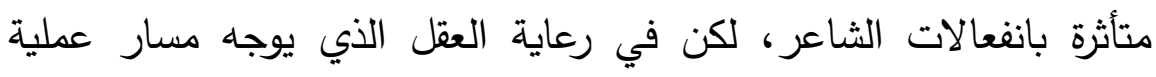
التخيل، ويضبطها ضبطا يتناسب مع طبيعة المحاكاة باعتبارها تثكيلا للأشياء الموجودة في الأعيان، لا يخرج في النهاية عن المككن أو المحتمل

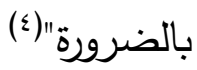
وعلى الرغم من إلحاح البارودي على إبراز وظيفة الثعر ماتلة في الناحية

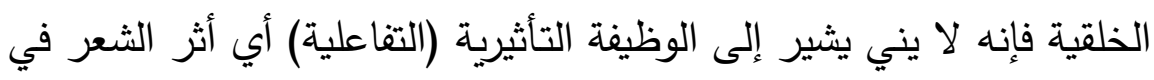

$$
\begin{aligned}
& \text { (1) ذاته } 79 \text { ا. } \\
& \text { (r) ذاته. . . (r. }
\end{aligned}
$$

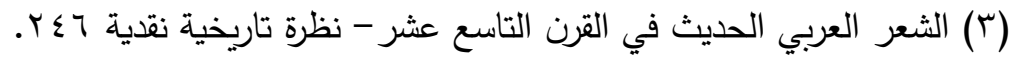

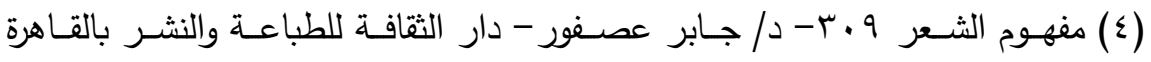
$.019 \vee \wedge$ 
المتلقي (المستقبل)، فالثعر -على حد تعبيره- ذو حدين، يرفع ويخفض، إذ يقول: [من البسيط] (')

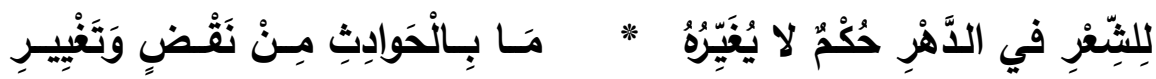

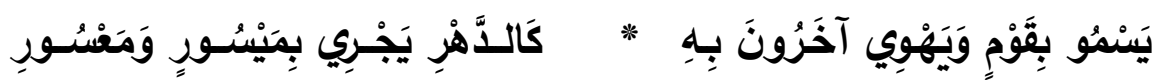
ومرة يشتد ويرق كما قوله: [من الطويل](؟)

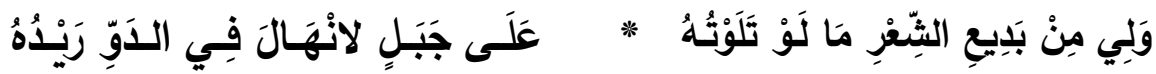

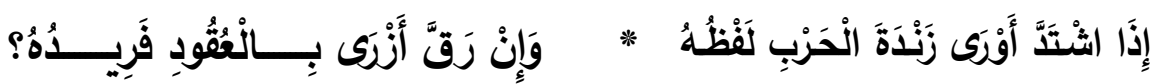
ومرة يكون زهرة في رقتها وسنانا حادا قاطعا في الجيوش العظيمة كما في قوله: [من الطويل] (r) فَطَوْزًَا تََرَاهُ زَهْرَةً بَيْنَ مَجْلِسِ ومرة يجمع بين الحماسة واللهو في آن كما في قوله: [من الطويل] (ء)

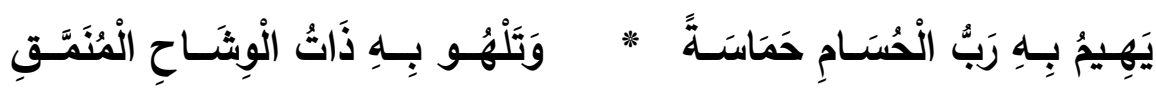

وقريب من هذا المعنى قوله: [من الطويل]ته

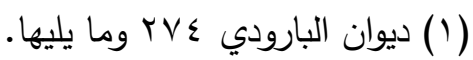

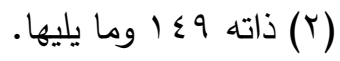

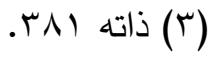
(§) ذاته رץr. (0) ديوان البارودي ماس وما يليها. 


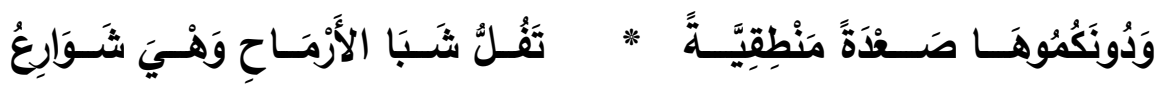

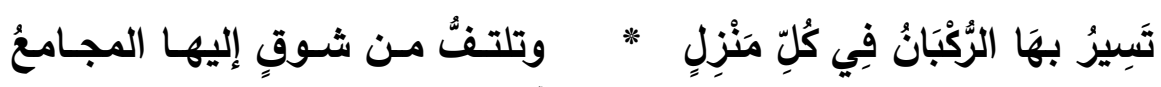

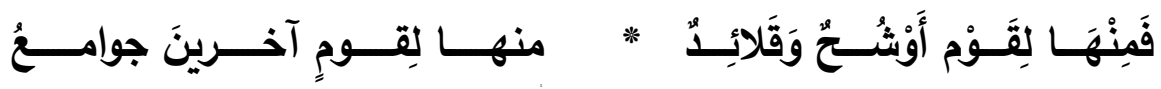

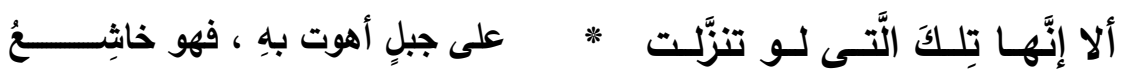
أي أن منهم من يتخذ قصسائده قلائد يتزينون بها، ومنهم من تكون هذه

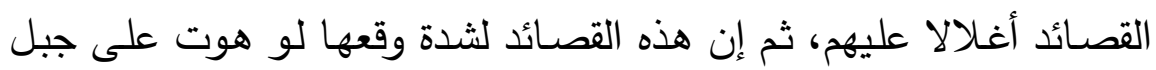
لانهار واندثر، وهو هنا ينحو منحى قرآنا مع الفارق بين المؤثرين، وكأنها

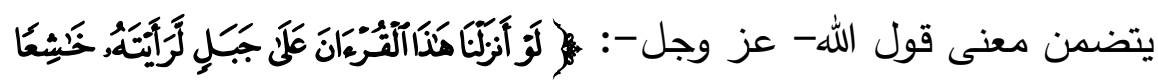

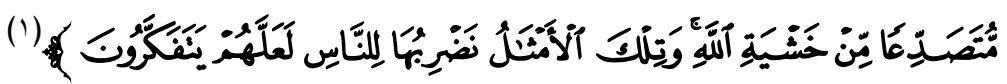
وقول البارودي: "فنها لقوم أوشح إلخ البيت يتناص مع قول أبي تمام: [من

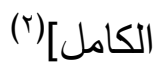

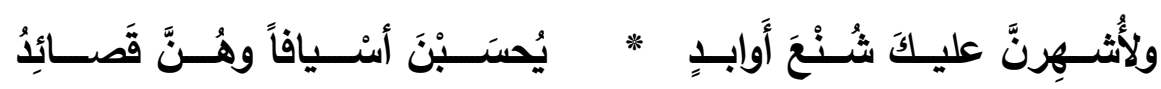

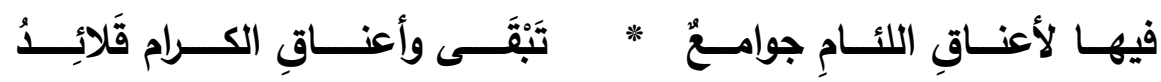
كما يجمع بين الفقد والهداية في قوله: [من البسيط](")

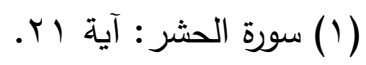

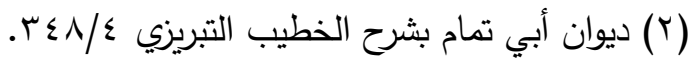

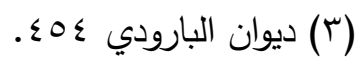




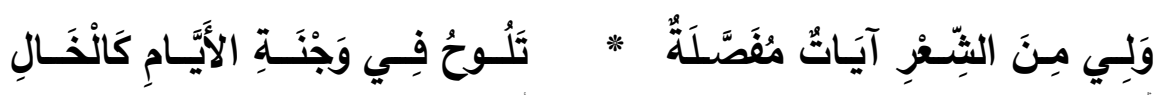

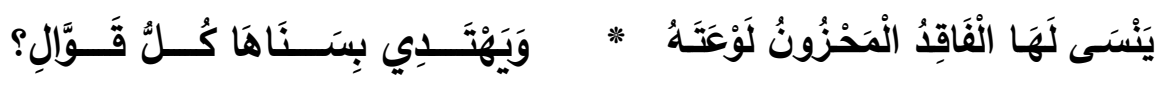
ولا يزال هذا ديدنه في الجمع بين الثنائيات الضدية، فيقول: [من البسيط](')

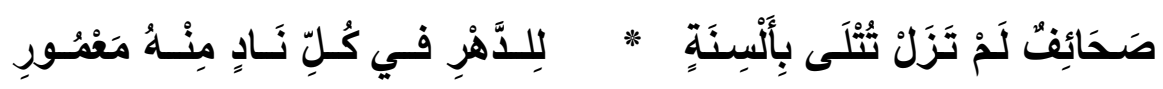

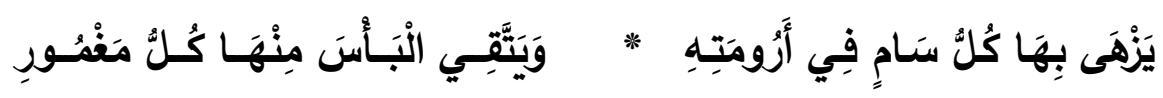

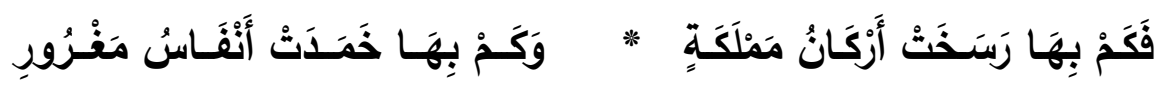

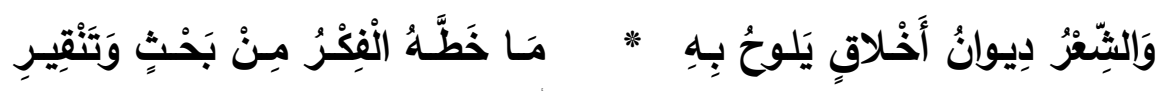

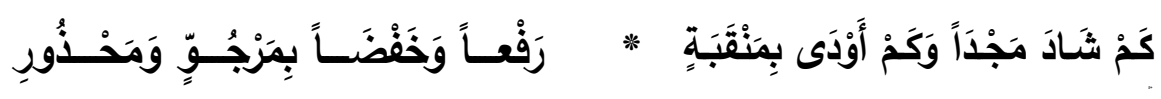

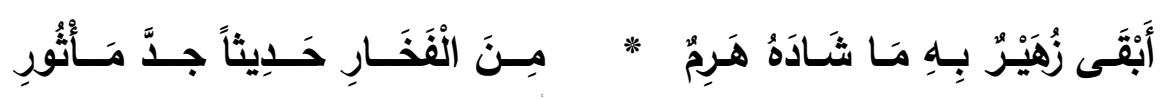

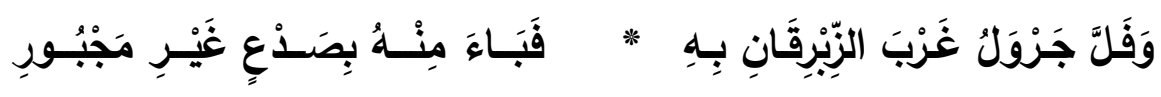

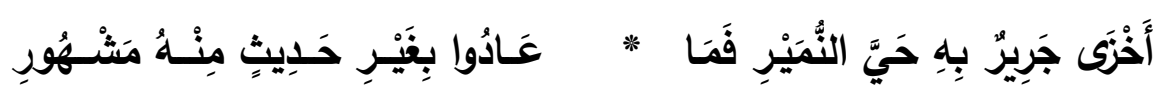

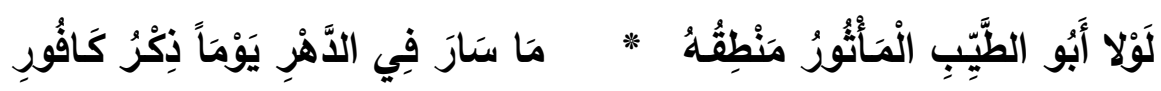
والبارودي في الأبيات الأربعة الأخيرة يشير إلى وظيفة الثعر التأثيرية وكأنه

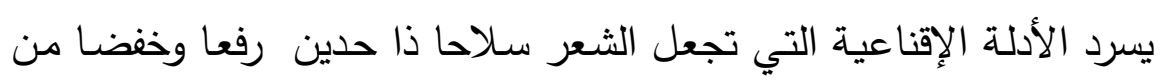
(1) (1) ديوان البارودي ع Y وما يليها. 
خلال الحديث عن مدح زهير لهرم بن سنان الذي كان لـه الدور الأكبر مـع الحارث بن عوف في إخماد رحى الحرب الطاحنة بين قبيلتي عبس وذبيان والمسماة بحرب داحس والغبراء، وهو هنـا يشير إلى قيمـة ذلك المـدح من

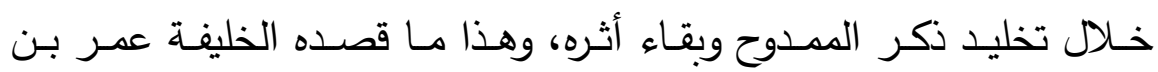
الخطاب رضي الله عنه حينما قال لبعض ولا هرم بن سنان: "أنشدني بعض وهل ما قال فيكم زهيرٌ ، فأنثده، فقال: لقد كان يقول فيكم فيحسن، فقال: يا أمير المؤمنين إنا كنا نعطيه فنجزل! فقال عمر رضي الله عنه: ذهب ما أعطيتموه وبقي مـا أعطاكم"('). ولا يني زهير يشير إلى هجاء الحطيئة للزبرقان بن بدر في سينيته الذائعة، وهجاء جرير لبني نمير قوم الراعي النميري، هذا

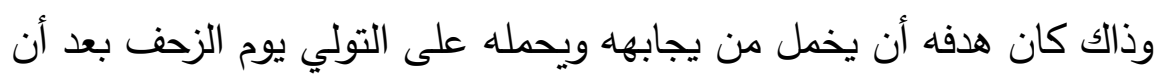

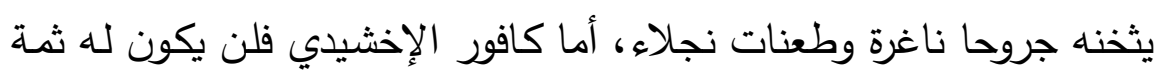
ذكر إذا لـم يـذكره المتتبـي في شعره، حتى أضـحت قصــائده فيـه مسـماة بالكافوريات.

ولعل من ينعم النظر في قراءة ديوان البارودي يجد ثمة وظائف أخرى للشعر، وهذا ما حرره د/ جابر عصفور في قوله "فالوظيفة الاجتماعية الغالبة للشعر لديه تتبلور في ضوء نظرة أخلاقية عملية لم تمنع من وجود نظرات سياسية أقل سطوة وهيمنة، وإن كانت ذات أثر ملحوظ في اتساع النظرة الأولى، لتندمج النظرتان في تكوين أساس اجتماعي سياسي في آن، خاصة بعد أن انبرى البارودي للدفاع مصالح القوة ومبادئها، فأضحى الثعر لديه- بجانب كونه ديوان أخلاق- "تعبيرا دعائيا في المجالات السياسية

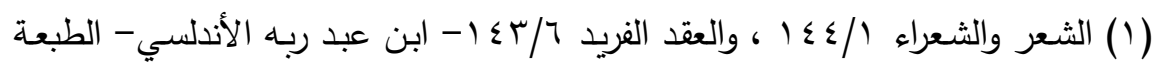

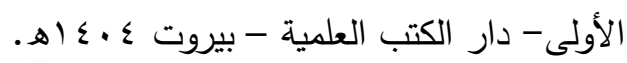


والاجتماعية، ولم يعد الثاعر معلما للفضيلة فحسب، بل أصبح خطيبا

وطنيا وداعية سياسيا" (')

ولا شك أن الوظيفة الاجتماعية كان لها تأثيرها في طبيعة الصورة الثعرية

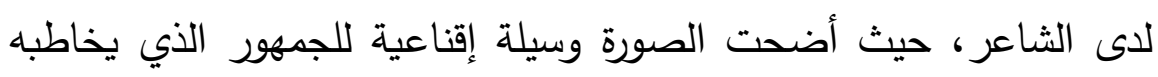

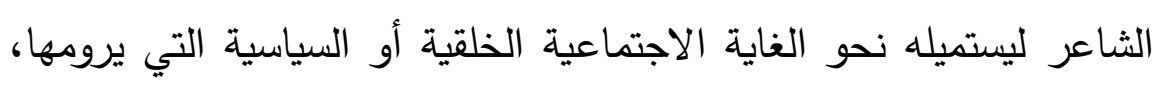

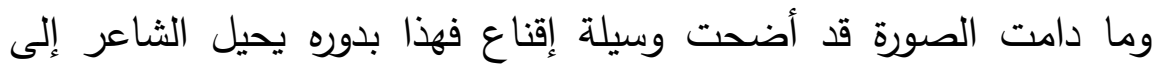

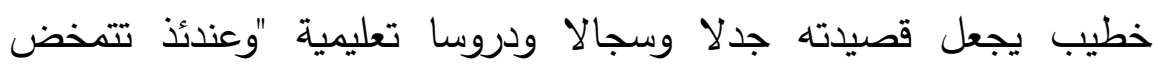

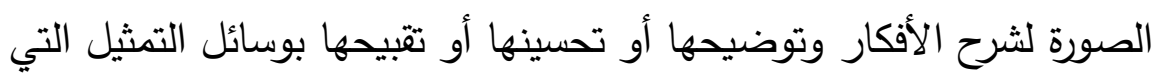

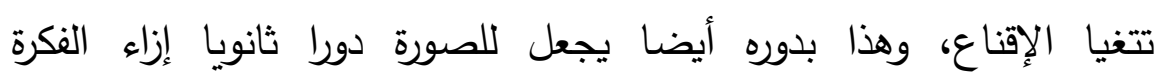
(الأساس) التي يروم الثاعر إقناعنا بها. وهنا يقول د/ جابر عصفور : "والإقناع أساليبه متتوعة في هذا السياق، فقد

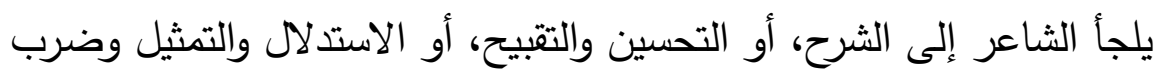

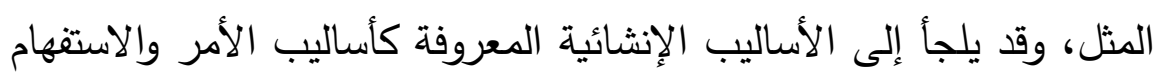

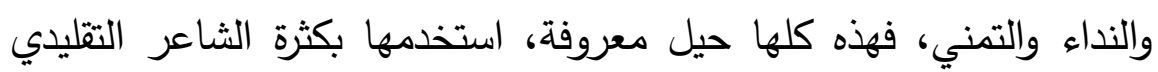

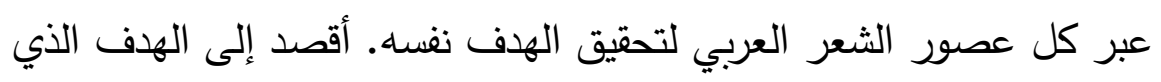

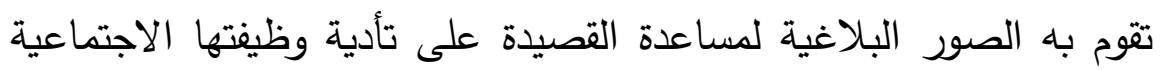

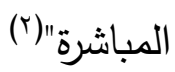

ومن ينعم النظر في ديوان البارودي يجد أنه عول على تثبيه التمثيل أو التورئ

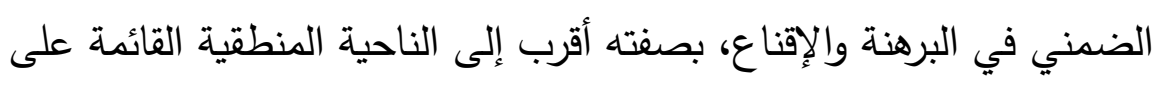

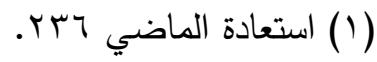

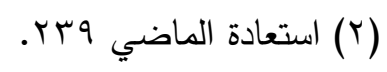


القياس والاستدلال، وهذا من حسن صنعة الثاعر الذي يقلب الفكر في قصيدته، ألا تراه يقول: [من الطويل]'(')

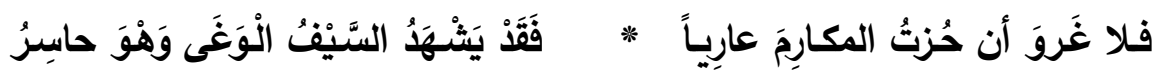
ويقول: [من البسيط][(ب)

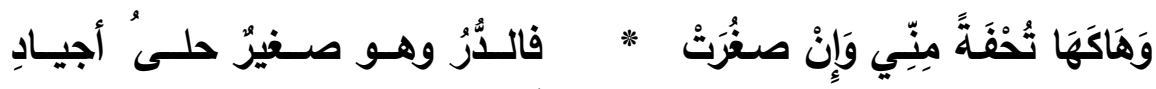
ويقول: [ من الكامل](r) (2)

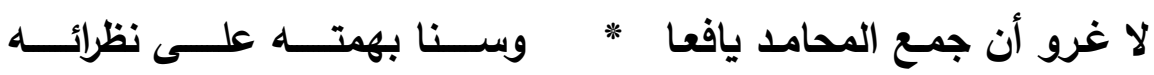
فالعين وهي صـغيرة في حجمها * تســع الفضــاء بأرضــه وســائه ويقول: [من البسيط][)

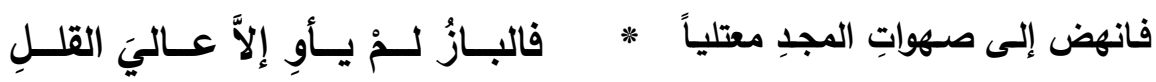
() ويقول: [من البسيط]

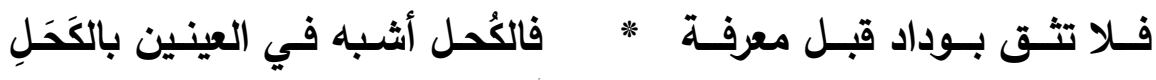

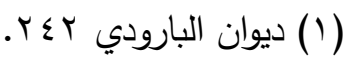

$$
\begin{aligned}
& \text { (r) ذاته }
\end{aligned}
$$

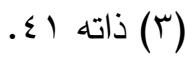

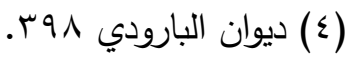

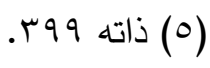


ويقول: [ من البسيط] (')

فإن يكن ساء هم فضلي فلا عجب فالشسمس وهي ضياء آفة المقل نزهت نفسي عمـا يدنسون بـه * ونحلة الروض تأبى شيمة الجعل وأحيانا يعول البارودي على ضرب المثل للإقناع، "وهو يقوم عادة على قصة مجازية، قد تكون ذات أصل تاريخي أو لا تكون، يؤكد مغزاها الفكرة التي يحاول الثاعر إقناع القارئ بها"(r) ومن ذلك قصيدته التي مطلعها: (من الطويل][)

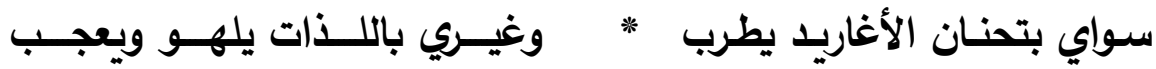
فواضح أن القالب الفني لهذه القصيدة هو قصيدة امرئ القيس الطردية. ومن ذلك قصيدته التي مطلعها: [من البسيط](؛)

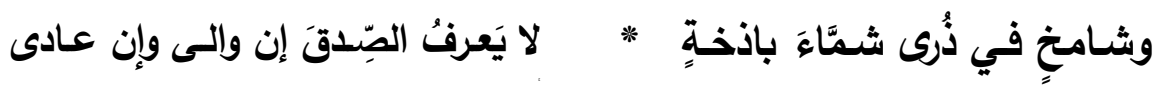
ويأبى الثاعر كذلك إلا أن يجعل لشعره وظيفة إعلامية، ومن ذلك في

مدح الخديوي إسماعيل قول: [من الطويل](ن) 


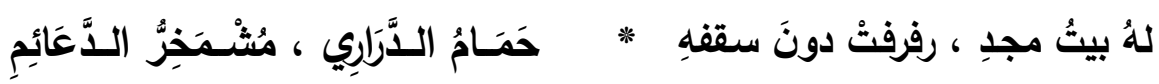

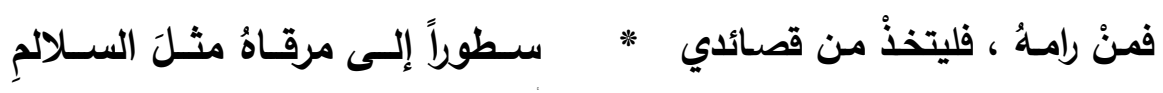
ثم نراه يقول عن شعره في قصيدة أخرى: [من البسيط](')

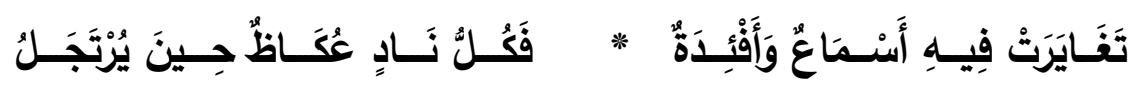

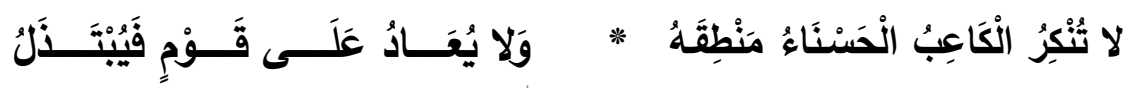

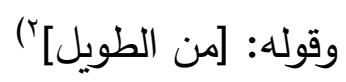

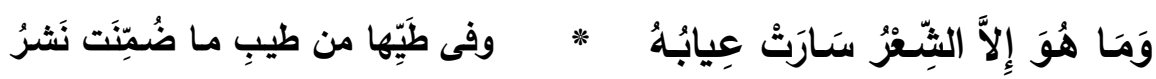

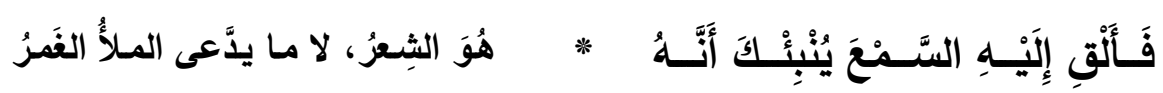
ومن ثم فوظيفة الشعر عند البارودي متعددة ولكنها ترتد في المقام الأول إلى الناحية الخلقية التهذيبية. أو من الناحية الخلقية تفرع ما عداها من الوظائف الاجتماعية والسياسية والإقناعية والإعلامية. 


\section{الفاتمة}

ا- بعد رصد أهم الرؤى النقدية للبارودي للشعر من شعره ندرك أنها لا تعدو أن تكون مجالا رحبا للتعريف بنفسه وإلقاء الضوء عليها من خلال الفخر بشعره، أو مجالا خصبا لصوغ المفاهيم النقدية الخاصة عن الفن الشعري والكثف عن النموذج الأمثل للشاعر الذي يريد أن يبذ أقرانه، كما أن بعض هذه الرؤى جاء في شكل وصايا شعرية

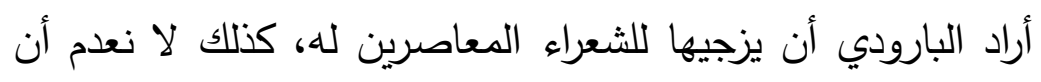
نجد بعض الرؤى أشبه بالبيان الثعري الذي يصوغ المبادئ الأساسية لفن الشعر، وأخرى أشبه بالإشارات المكرورة داخل قصائده مما يدخل في باب الشعر الشارح.

r-صارت وظيفة الشعر عند البارودي أخلاقية يريد أن يقوم المجتمع من خلالها من ناحية وينتقد بها كثيرين من الشعراء الذين انحرفوا عن جادة الثعر، وانزلقوا إلى التملق الرخيص في المدح، مما أدى إلى التغرير بالممدوح من أغراض دنيئة ورديئة.

ب- لم تكن رؤى البارودي النقدية من شعره بدعا حاز بها قصب السبق، فلم تكن بمبعدة عن الشعراء النقاد من قبل البارودي من أمثال

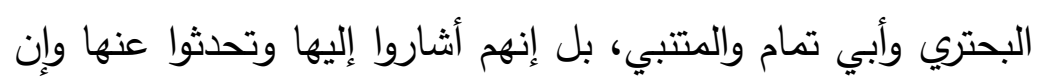
كانت لا تعدو - والأمر عند البارودي كذلك- حديث الثاعر في شعره عن شعره (Meta Poetry)، ذلك الحديث المترع بالزهو والخيلاء وإبراز الفوقية والتبريز على الأقران والأنداد.

ع-لم يكن البارودي يتغيا من رصد تلك الرؤى أن يضع نفسه مع العيوق مكانة أو يرتفع إلى مصاف النقاد الكبار ومعارجهج، ولكن لين لين 
ليكثف لنا عن طبيعة الثاعر الواعي المثقف المتميز بين أبناء جيله.

0- مال البارودي إلى جانب الطبع المزوج بالتعهد والتجويد والتثقيف والتهذيب والتشذيب، ولا أدل على ذلك من اختلاف بعض القصائد في الديوان الذي طبع لاحقا عن طبعة الوسيلة الأدبية

ج- جاءت معظم الأبيات التي بث فيها البارودي رؤاه تحتل مساحة لا بأس بها من القصيدة، بل لا أجانب الصواب إن قلت إن معظمها وقع في خاتمة القصائد التي تكتنز هذه الرؤى، ولذلك دلالته الخاصة في تعدد البارودي أن يجعل خاتمة القصيدة لديه تحمل بعدا فنيا ونقديا يقدحه بزناد فكره ويقدمه جنى دانيا لأصحاب الذائقة والبصر بالثعر - 


\section{تَبَتَّْ المصادرِ والمراجِمِ}

أولا: القرآن الكريم:

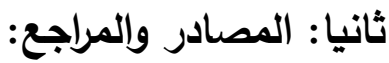

1- إحياء الثعر - عارف حجاوي - الطبعة الأولى - دار المشرق بالقاهرة

$$
\cdot 5 r \cdot 11
$$

r- الأدب العربي المعاصر في مصر - د شوقي ضيف- الطبعة العاشرة-

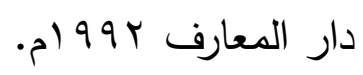

ب- اسـتعادة الماضـي "دراسـات في شـعر النهضــة - د/ جـابر عصـفر -

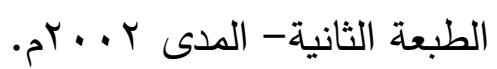

ع - أسرار البلاغة- عبد القاهر الجرجاني- قرأه وعلق عليه: محمود محمد شاكر - نشر مطبعة المدني بالقاهرة، دار المدني بجدة.

ه- الأغـاني - أبـو الفـرج الأصـفهاني - تحقيـق/ سـمير جـابر - الطبعـة

$$
\text { الثانية- دار الفكر - بيروت. }
$$

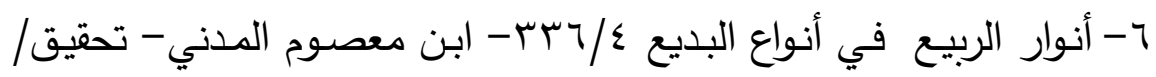

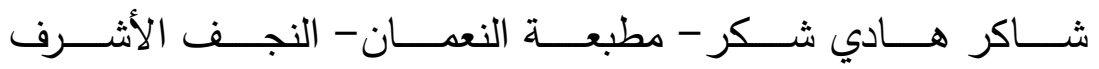

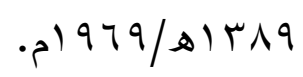

V- البارودي رائد الشـر الحديث- د/ شوقي ضيف- طبعـة دار المعـارف

$$
\text { . } 919
$$

1- البديع - ابن المعتز - اعتنى بنشره وتعليق المقدمة والفهارس/ إغناطيوس كراتثقوفسكي - دار المسيرة بيروت. 
9- البديع في نقد الشعر - أسامة بن منقذ- تحقيق د/ أحمد أحمد بدوي، د/ حامـد عبد المجيـد- مراجعـة أ/ إبـراهيم مصـطفى - الجمهوريـة العربيـة المتحـدة - وزارة الثقافـة والإرشـاد القـومي - الإقلـيم الجنـوبي - الإدارة العامة للثقافة.

• 1- البيان والتبيين - الجاحظ ـ تحقيق وشرح/ عبد السلام هارون - تقديم د/ عبد الحكيم راضي - سلسلة الذخائر - الهيئة العامـة لقصور الثقافة

$$
\text { . }
$$

1ا-تحرير التحبير في صناعة الثعر والنثر وبيان إعجاز القرآن - ابن

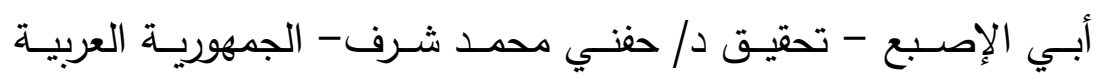
المتحدة - المجلس الأعلى للشئون الإسـلامية - لجنـة إحيـاء التراث الإسلامي. ז - جمهرة الأمثال - أبو هلال العسكري- دار الفكر - بيروت. ب ا - الحماسـة الثـجرية - ابـن الثـجري- تحقيقق/ عبد المعين الملـوحي،

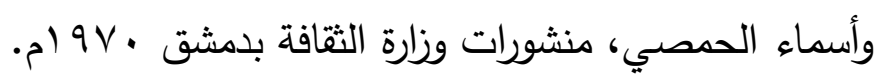
ع ا- الحيـوان - الجـاحظ- الطبعـة الثانيـة- دار الكتـب العلميـة - بيـروت . ه

10- خزانـة الأدب ولب لباب لسان العرب- البغدادي- تحقيق/ محمد نبيل طريفي، وإميل بديع يعقوب- دار الكتب العلمية بيروت- 9 ه ام. 7 ا-دلائل الإعجاز في علم المعاني - عبد القاهر الجرجاني- تحقيق/ محمود محمد شاكر أبو فهر - الطبعة الثالثة- مطبعة المدني بالقاهرة -

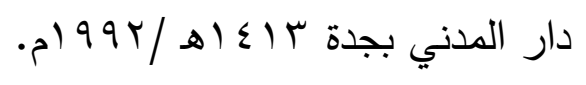


IV - ديوان ابن زمرك محمد بن يوسف الصريحي - تحقيق د/ محمد توفيق النيفر - الطبعة الأولى - دار الغرب الإسلامي لو إم.

1 ا - ديوان أبي تمام بشرح الخطيب التبريزي- تحقيق محمد عبده عزام-

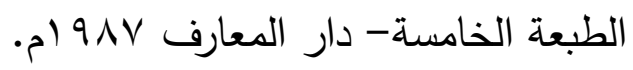

9 ا - ديوان أبي نواس(الحسن بن هانئ) - حققه وضبطه وشرحه/ أحمد عبد المجيد الغزالي - نشر دار الكتاب العربي - بيروت لبنان.

• ץ- ديوان الأمير شكيب أرسلان - وقف على طبع القسم الأكبر من هذا

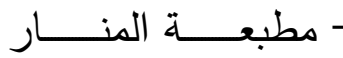

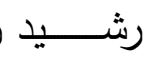
ر

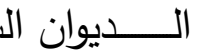

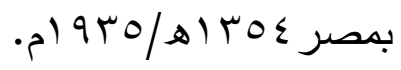

ا (Y-ديوان البارودي - حققه وضبطه وشرحه/ علي الجارم، ومحمد شفيق معروف- دار العودة ببيروت 991 ام.

r ب- ديوان البحتري- تحقيق وشرح وتعليق/ حسن كامل الصيرفي- الطبعة الثالثة- دار المعارف بمصر ع 9 ام.

rץ- ديوان بشار بن برد- شرح وتكميل/ محمد الطاهر بن عاشور - راجع مخطوطته ووقف على ضبطه وتصـحيحه/ محمد شوقي أمين - لجنـة

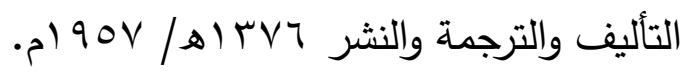
ع ץ- ديـوان الخنسـاء بشـرح ثعلب - تحقيق د/ أنـور أبـو سويلم- الطبعـة

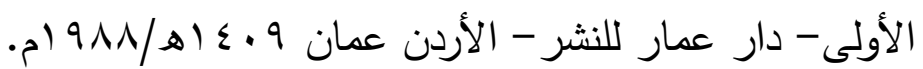
0 - ديـوان طرفـة بـن العبد بشـرح الأعلم الثـنتمري ع V ا - تحقيـق/ دريـة الخطيب ولطفي الصقال - إدارة الثقافة والفنون بدولة البحرين - المؤسسة العربية بيروت لبنان - توزيع دار الفارس بعمان - الأردن . . . بم. 
ج - الخصـائص- ابن جني- تحقيق/ محمد علي النجار - عالم الكتببيروت.

V - ديوان عدي بن الرقاع العاملي شاعر أهل الثام - جمع وشرح ودراسـة

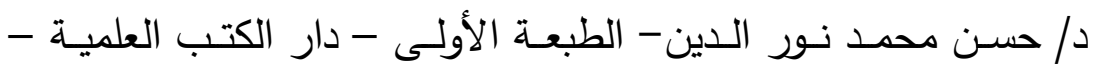

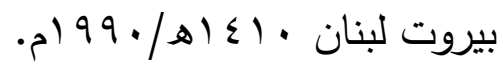

$$
\text { ^ץ- رسائل الرافعي- الدار العمرية (د.ت) }
$$

q - سقط الزند - أبو العـلاء المعري- دار بيروت للطباعة والنشر - دار

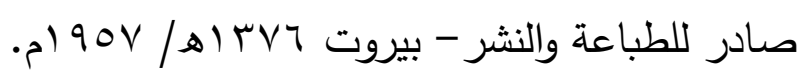

• ب-شـرح ديـوان عنتـرة - الخطيـب التبريـزي - قدم لـه ووضـع هوامشـــ

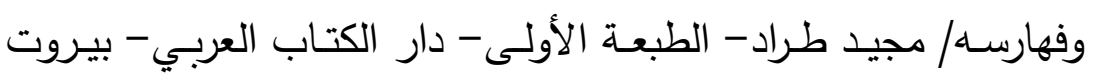
. $994 / 81 \leq 14$

اس-شرح ديوان الفرزدق - إيليا الحاوي- منشورات دار الكتاب اللبنانيمكتبة المدرسة.

rس-شرح ديوان المتنبي - البرقوقي - دار الكتاب العربي- بيروت لبنان. سب-شرح المعلقات السبع - الزَّوْزَني - الطبعة الأولى - دار احياء التراث

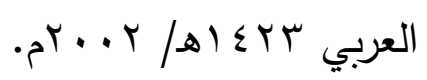

ع - شعراء مصر وبيئاتهم في الجيل الماضـي - العقاد- مطبعـة حجازي

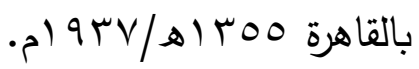

هب- الشعراء نقادا- د/ عبد الجبار المطلبي- الطبعة الأولى- دار الشئون الثقافية العامة- بغداد- T19 ام. 
جب-شعر دعبل بن علي الخزاعي- صنعة د/ عبد الكريم الأشتر - الطبعة

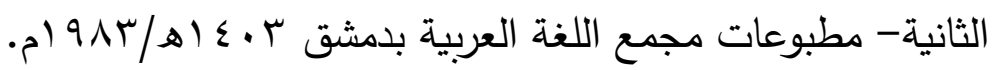

- الشعر العربي الحديث في القرن التاسع عشر - نظرة تاريخية نقدية

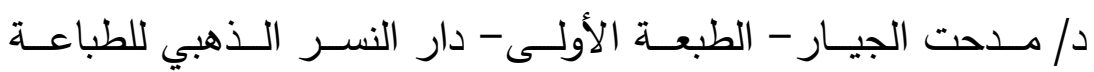

$$
\text { . }
$$

مب- الثـعر والثـعراء - ابن قتيبـة الدينوري - تحقيق وشـرح/ أحمد محمد

$$
\text { شاكر - دار المعارف ra و ام. }
$$

qب-صـيح البخاري - تحقيق/ محمد زهير بن ناصـر الناصـر - الطبعة الأولى - دار طوق النجاة (مصورة عن السلطانية بإضـافة ترقيم ترقيم

$$
\text { محمد فؤاد عبد الباقي) r r الهـ أهـ }
$$

• ع- الصناعتين - أبو هلال العسكري- تحقيق/ علي محمد البجاوي ومحمد

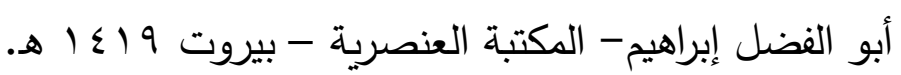

اء- طبقات فحول الشعراء - ابن سلام الجمحي- تحقيق/ محمود محمد

$$
\text { شاكر - دار المدني - جدة. }
$$

ץء- العقد الفريد - ابن عبد ربـه الأندلسي- الطبعـة الأولى - دار الكتب

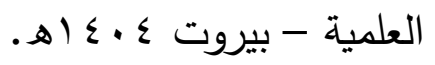

بـ- العددة في محاسن الثعر وآدابه ونقده - ابن رشيق القيرواني- تحقيق/ محمد محيي الدين عبد الحميد- الطبعة الخامسة- دار الجيل- بيروت-

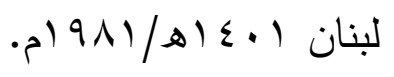

؟ ـ- الفن ومذاهبه في الثـعر العربي - د/ شوقي ضـيف- الطبعة الثانية

عشرة- دار المعارف بمصر • 
رؤى البارودي النقلية من شعره

0ـ- في الأدب الحديث (ج) ( عمر الدسوقي- طبعـة دار الفكر العربي

$$
\text { . . . . . }
$$

جـ- قواعد الثعر - أبو العباس المعروف بثعلب- تحقيق د/ رمضـان عبد التواب- الطبعة الثانية- مكتبة الخانجي - القاهرة- 990 ام.

§V

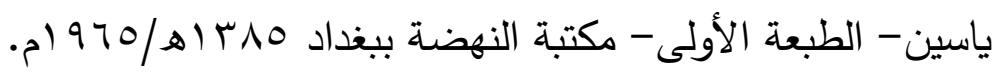

يـ - لسـان العـرب- ابـن منظـور - الطبعـة الثالثـة - دار صـادر بيـروت .ه) $\leqslant$ )

9 - المؤتلف والمختلف- الآمدي- صححه وعلق عليه أ.د/ ف. كرنكو-

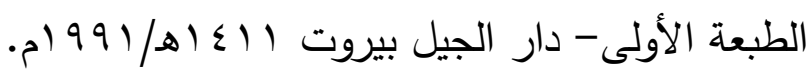
• - مجمـع الأمثال - الميداني- تحقيق/ محيى الدين عبد الحميد- دار

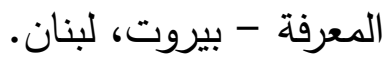

10- محاضرات الأدباء ومحاورات الثعراء والبلغاء - الراغب الأصفهاني-

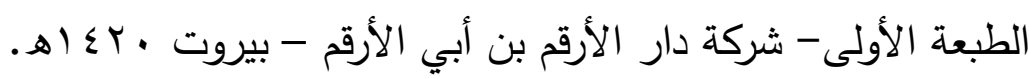
r-Or- محمود سامي البارودي شاعر النهضـة - د/ علي الحديدي- الطبعة

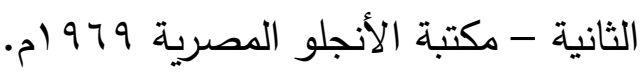

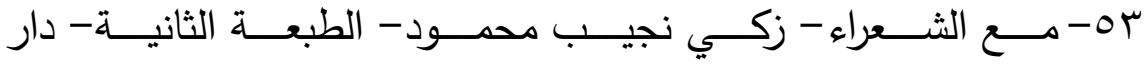

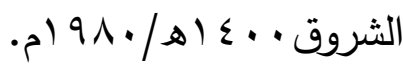


ع ه- مفاهيم نقدية- رينيه ويليك- ترجمة/ محمد عصفور - عالم المعرفة-

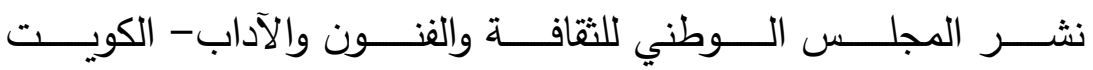

$$
\text { . ) } 9 \wedge V / \text { ه I } \varepsilon \cdot V
$$

00- المفصـل فى تـاريخ العـرب قبـل الإسـلام - د/ جـواد علي - الطبعـة

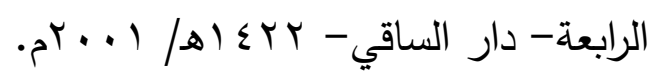

Tه- المفضليات - المفضل الضبي- تحقيق وشرح/ أحمد محمد شـاكر و عبد السلام محمد هارون - الطبعة السادسة- دار المعارف بالقاهرة. - مفهوم الشعر - د/ جابر عصفور - دار الثقافة للطباعة والنشر بالقاهرة

$$
\cdot \text {. } 9 \vee \wedge
$$

101- مقدمـة ابن خلدون - ابن خلدون- تحقيق وشرح د/ علي عبد الواحد

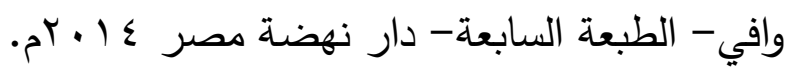

9ه- المنزع البديع في تجنيس أساليب البديع - السجلماسي - تقديم وتحقيق/

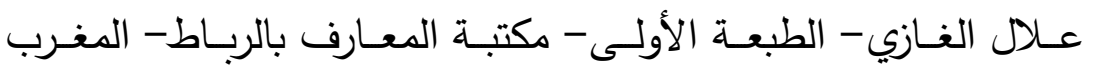

$$
\text { - } 191 \cdot / 81 \leq \cdot 1
$$

• - - منهـاج البلغـاء وسـراج الأدبـاء - حـازم القرطـاجني- تحقيـق/ محمــ

$$
\text { الحبيب بن الخوجة- دار الغرب الإسلامي د.ت التهاء) }
$$

آ- موسيقى الثـعر - د/ إبراهيم أنيس- الطبعـة الثانيـة- مكتبـة الأنجلو

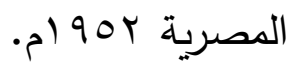

با- الموشـح - المرزبـاني - تحقيق/ علـي محمد البجاوي - نهضــة مصـر للطباعة والنشر • 
سج- النقــد الإحيـائي وتجديـد الثـعر في ضــوء التـراث- د/ عبـد الحكيم

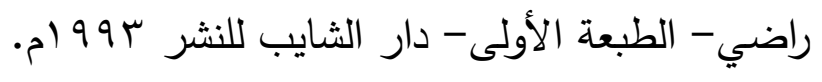

ـ ؟- نقد الشعر - قدامة بن جعفر - تحقيق د/ محمد عبد المنعم خفاجي-

$$
\text { دار الكتب العلمية- بيروت لبنان. }
$$

07- هاجس الخلود في الثـعر العربي حتى نهايـة العصـر الأموي - عبد

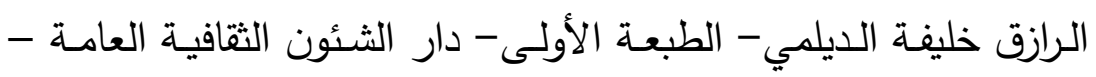

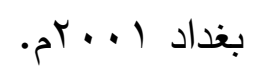

7 7- الوسيلة الأدبية- المرصفي- الطبعة الأولى - مطبعة المدارس الملكية

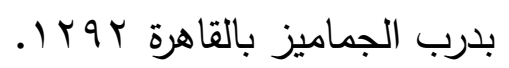

\section{ثالثا: المجلات والاوربيات}

(1) ابـن الرومسي ناقـدا، لجاسـر خليـل سـالم أبـو صـفية- حوليـات الآداب والعلـوم الاجتماعيـة، مجلس النشـر العلمـي، جامعـة الكويــ، الرسـالة

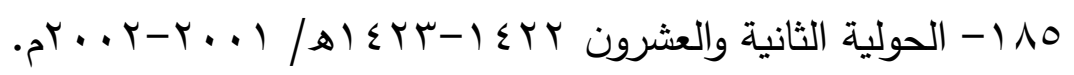

(Y) الإلهام والإبـداع الثـعري في الثـعر العربـي الحديث - جهاد شـاهر

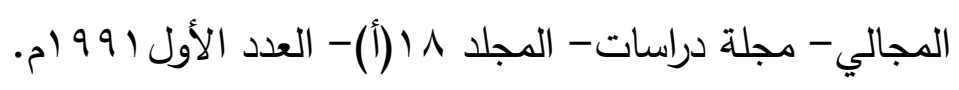

(r) رؤية أبي تمام للشعر من خلال ديوانه- مصطفى حسين محمد عناية-

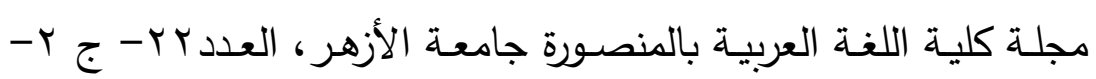

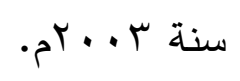

رؤية الثاعر لشعريته - قراءة نقدية في نصوص البحتري والمتنبي- د/

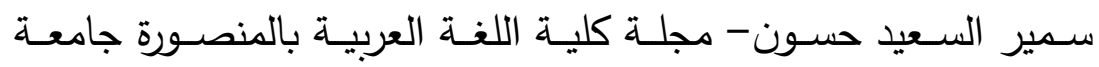

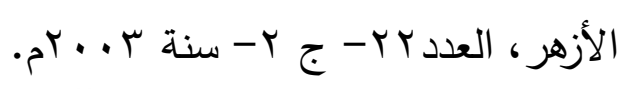


(0) شـعر صـبري - مصـطفى صـادق الرافعي- مجلـة المقتطف - العـدد الخامس الصادر في امايو سبو (م. في صـلة الثـعر بالسـر - د مبـروك المنـاعي- حوليـة كليـة الآداب والفنون والإنسانيات-جامعة منوبة- عدد اس- سنة . 99 ام. (V) قضـية الثـاعر الناقد-الناقد الثـاعر - الشـاعر والنقد: دراسـة في النقد القديم- قاسم المومني- مجلة جامعة دمشق في العلوم الإنسانية- المجلد

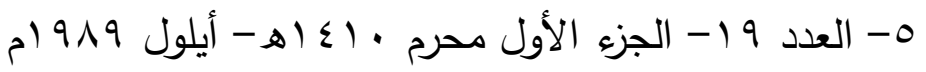

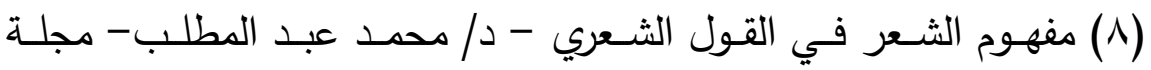

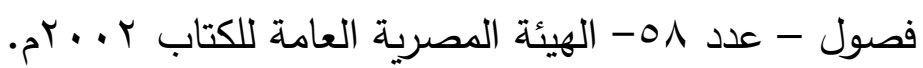
(9) المفهوم النظـري للشـعر عند البـارودي وشـوقي - د/ أحمد بـن صـالح الطامي- بحث منشور بكلية الآداب جامعة الملك سعود- المجلد برا -

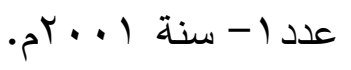

( • (1) نفسية البارودي من خلال شعره - عمر محمد- مجلة آداب الرافدين-

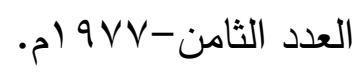


رؤى البارودي النقدية من شعره

مسترد الموضو عات

الموضوع

المقدمة

التمهيد

أولا: جدلية الثاعر الناقد والناقد الثاعر:

ثانيا: الدراسات السابقة:

المبحث الأول: الشعر بين الطبع والصنعة.

المبحث الثاني: خلود الثعر لصاحبه بعد موته.

المبحث الثالث: التقوق على الآخر .

المبحث الرابع: أوصاف "الثعر" القصيدة.

المبحث الخامس: وظيفة الشعر.

الخاتمة

ثبت المصدر والمراجع

مسرد الموضوعات 